\title{
Ground-Water Geochemistry of the Columbia Plateau Aquifer System, Washington, Oregon, and Idaho
}

By W.C. Steinkampf and P.P. Hearn, Jr.

A contribution of the Regional

Aquifer-System Analysis Program

U.S. Geological Survey

Open-File Report 95-467

Tacoma, Washington

1996 


\title{
U.S. DEPARTMENT OF THE INTERIOR
}

BRUCE BABBITT, Secretary

\author{
U.S. GEOLOGICAL SURVEY
}

Gordon P. Eaton, Director

Any use of trade, product, or firm names is for descriptive purposes only and does not imply endorsement by the U.S. Government.

For additional information write to:

District Chief

U.S. Geological Survey

1201 Pacific Avenue - Suite 600

Tacoma, Washington 98402
Copies of this report may be purchased from:

U.S. Geological Survey

Branch of Information Services

Box 25286, MS 517

Denver. Colorado 80225-0286 


\section{CONTENTS}

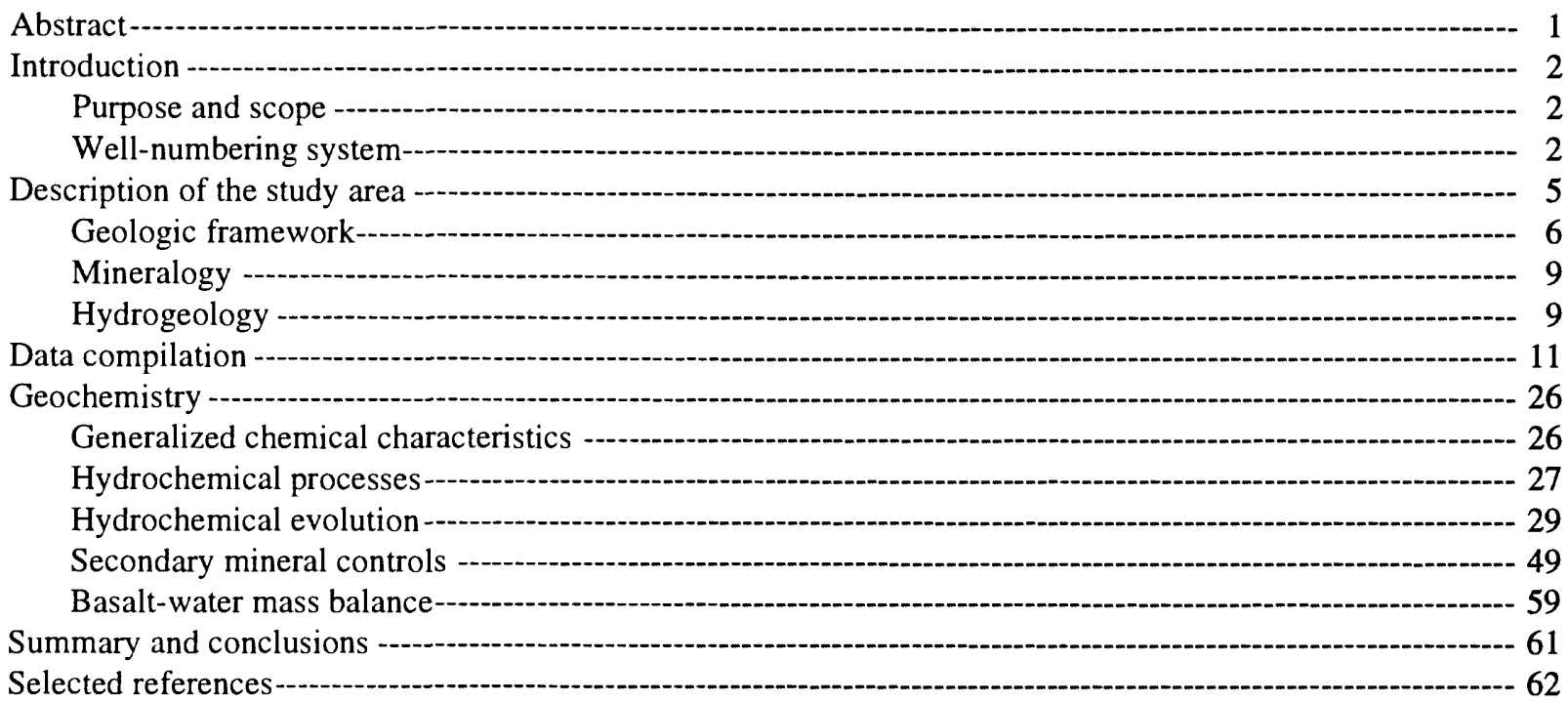

\section{FIGURES}

1. Map showing location of the Columbia Plateau aquifer system and physiographic subprovince boundaries-- 3

2. Diagram showing well-numbering system-- 4

3. Map showing generalized extent of the Columbia River Basalt Group within the study area --.---.---- 6

4. Chart showing generalized stratigraphy of the Columbia Plateau and the relation between geologic and hydrologic units ---on

5-7. Maps showing potentiometric surface of the:

5. Saddle Mountains unit--.- 12

6. Wanapum unit -- 13

7. Grande Ronde unit - 14

8. Graph showing average oxygen-18 and deuterium ratios for samples from wells in the Grande Ronde unit in which dissolved nitrogen concentrations are less than 1.0 milligram per liter

9. Map and graph showing (A) areal distribution of averaged sodium concentrations, and

(B) relation between averaged sodium concentrations and well depth for the Grande Ronde unit -

10-11. Graphs showing relation between:

10. Averaged dissolved solids and sodium concentration for the Grande Ronde unit -

11. Averaged uncorrected radiocarbon age and (A) sodium, and (B) calcium concentrations for the Grande Ronde unit -

12-13. Piper diagrams of:

12. Relative molar calcium, magnesium, and sodium concentrations for selected sites in the Horse Heaven Hills, grouped by radiocarbon values

13. Ground water from selected wells in the (A) Wanapum unit in the Horse Heaven Hills, and (B) Grande Ronde unit

14. Graphs showing relation between averaged calcium and sodium concentrations for (A) the Grande Ronde unit and (B) selected sites in the Horse Heaven Hills 


\section{FIGURES--CONTINUED}

15. Map showing the potentiometric surface of the Wanapum unit in the Horse Heaven

Hills, spring 1980, and locations of selected hydrochemical data-collection sites

16-29. Graphs showing relation between:

16. Averaged uncorrected radiocarbon age and (A) potassium:sodium ratios and

(B) calcium:sodium ratios for the Grande Ronde unit

17. Averaged chloride and sodium concentrations for the Grande Ronde unit -

18. Averaged uncorrected radiocarbon age and chloride concentration for the Grande

Ronde unit-

19. Estimated and measured chloride concentrations for two Grande Ronde unit sites with uncorrected radiocarbon ages of 7,150 and 27,950 years

20. Chloride and sodium concentrations for selected sites in the Horse Heaven Hills

21. $\mathrm{pH}$ and sodium concentrations for the Grande Ronde unit and selected sites in the Horse Heaven Hills

22. Carbon dioxide partial pressure and $\mathrm{pH}$ for $(\mathrm{A})$ the Grande Ronde unit and (B) the Horse Heaven Hills

23. Averaged dissolved-oxygen concentration and well depth for the Grande Ronde unit

24. Calculated dissolved silica activity and ground-water temperature for the Grande

Ronde unit and selected sites in the Horse Heaven Hills

25. Calcite saturation index and $\mathrm{pH}$ for the Grande Ronde unit- 54

26. Carbon dioxide partial pressure and silica activity for selected sites in the Horse Heaven Hills

27. Calcite ion activity product and ground-water temperature for the Grande Ronde unit and selected sites in the Horse Heaven Hills

28. Calcite saturation index and dissolved sodium concentrations for the Grande Ronde unit and selected sites in the Horse Heaven Hills

29. Dissolved-solids residue and dissolved sodium concentrations for selected wells in the Horse Heaven Hills

\section{TABLES}

1. Compositions and formulas of basaltic glass, smectite, and clinopitolite from the Columbia River Basalt Group

2. Summary of selected hydrochemical data for ground water in three basalt hydrogeologic units -......- 15

3. Selected mole ratios in basaltic glass and ground waters in the Horse Heaven Hills, Washington --.--- 17

4. Selected site and hydrochemical information for selected Wanapum unit wells in the Horse Heaven Hills, Washington

5. Selected site and hydrochemical information for water from three wells in the Grande Ronde unit in the Columbia Plateau, Washington and Oregon, in which dissolved nitrogen concentrations are less than $1.0 \mathrm{mg} / \mathrm{L}$

6. Selected site and averaged hydrochemical information for water from wells in the Grande Ronde unit in the Columbia Plateau, Washington and Oregon, in which dissolved nitrogen concentrations are less than $1.0 \mathrm{mg} / \mathrm{L}$ 


\begin{tabular}{rll}
\multicolumn{1}{c}{ Multiply } & By & To obtain \\
\hline inch (in) & 2.54 & centimeter \\
foot $(\mathrm{ft} 0$ & 0.3048 & meter \\
mile $(\mathrm{mi})$ & 1.609 & kilometer \\
acre & 0.4047 & hectare \\
square mile $\left(\mathrm{mi}^{2}\right)$ & 2.590 & square kilometer \\
cubic mile $\left(\mathrm{mi}^{2}\right)$ & 4.168 & cubic kilometer \\
inch per year $\left(\mathrm{in}^{2} / \mathrm{yr}\right)$ & 2.54 & centimeter per year \\
cubic foot per second (ft/s) & 0.02832 & cubic meter per second \\
acre-foot (acre-ft) & 1,233 & cubic meter \\
pound $(\mathrm{lb})$ & 0.4536 & kilogram
\end{tabular}

Temperature: To convert temperature given in this report in degrees Fahrenheit $\left({ }^{\circ} \mathrm{F}\right)$ to degrees Celsius $\left({ }^{\circ} \mathrm{C}\right)$, use the following: ${ }^{\circ} \mathrm{C}=5 / 9\left({ }^{\circ} \mathrm{F}-32\right)$.

Sea Level: In this report "sea level" refers to the National Geodetic Vertical Datum of 1929 (NGVD of 1929)--a geodetic datum derived from a general adjustment of the first-order level nets of both the United States and Canada, formerly called Sea Level Datum of 1929.

\section{SYMBOLS AND DEFINITIONS}

Eh Oxidation potential, log activity of e1

IAP Ion activity product

ka Thousand years

$\mathrm{mg} / \mathrm{L} \quad$ Milligrams per liter

$\mathrm{P}_{\mathrm{CO}_{2}} \quad$ Partial pressure of carbon dioxide

$\mathrm{pH}_{2} \quad$ Negative log activity of $\mathrm{H}+$

pmc Percent modern carbon

ppm Parts per million

SI Saturation index

SMOW Standard mean ocean water 180 and $2 \mathrm{H}$ isotope standard

$\mathrm{mg} / \mathrm{L} \quad$ Micrograms per liter

$\mu \mathrm{S} / \mathrm{cm} \quad$ Microsiemens per centimeter at $25^{\circ} \mathrm{C}$

e1 Electron

$\delta{ }^{13} \mathrm{C}$ Carbon-13/carbon-12 ratio, in per mil PDB (Belemenitella americana Cretaceous Peedee Formation

14 of South Carolina)

${ }^{14} \mathrm{C}$ Carbon-14, in uncorrected percent modern

$\delta^{2} \mathrm{H} \quad$ Deuterium/hydrogen ratio, in per mil V-SMOW (Vienna-Standard Mean Ocean Water)

$\delta^{18} \mathrm{O}$ Oxygen-18/oxygen-16 ratio, in per mil V-SMOW 


\title{
Ground-Water Geochemistry of the Columbia Plateau Aquifer System, Washington, Oregon, and Idaho
}

\author{
By W.C. Steinkampf and P.P. Hearn, Jr.
}

\begin{abstract}
Basalt aquifers of Miocene age are the major sources of ground water for agricultural, domestic, and municipal uses for the Columbia Plateau. Agricultural withdrawals and extensive surface-water applications in the Columbia Basin Irrigation Project have affected both ground-water chemistry and flow in some parts of the aquifer system.
\end{abstract}

Ground waters primarily are dilute calcium-magnesium-bicarbonate and sodium-bicarbonate waters. The former generally are found in upgradient and recharge areas and the latter, downgradient and deeper in the system. Dissolved elemental concentrations, with the exception of divalent cations, increase downgradient. This general scheme is locally influenced by anthropogenic inputs and upward flux from deeper units. Spatial hydrochemical variations derive from water-rock interactions and the extent to which the aquifer system is isolated from the atmosphere.

Solute sources are basaltic glass, plateau precipitation, soil zone and atmospheric carbon dioxide, and possibly interlayered organic material. Dissolution, by hydrolysis and carbonic acid, yields initially stoichiometric relative solute concentrations, but subsequent reactions, ground-water mixing, secondary mineralization, and possibly ion exchange alter initial relations. Dissolved oxygen oxidizes ferrous iron and aluminum, and ferric iron rapidly precipitates as amorphous aluminosilicates and iron oxyhydroxides. Both phases tend to become more crystalline over time. The aluminosilicate additionally contributes to the removal of calcium, magnesium, sodium, iron, and silicon from solution. As dissolution proceeds, the $\mathrm{pH}$ increases to a point at which, in the most evolved waters, silicon species are perhaps important in hydroxyl ion concentration buffering. Calcite precipitation controls or affects calcium, inorganic carbon, iron, and magnesium concentrations. Silicon appears to be controlled by the precipitation of $\alpha$-cristobalite, and adularia and clinoptilolite have an additional effect in warmer and more evolved waters. Clinoptilolite also likely affects sodium and potassium concentrations, once they, together with silicon, reach sufficiently large concentrations.

Data from a ground-water flow path in the Horse Heaven Hills in south-central Washington suggest that local mixing of upward-flowing older, warmer, and more evolved water with overlying water increases calcite oversaturation, with a resultant decrease in calcium and magnesium concentrations and an overall "freshening" of the mixed water. This is contemporaneous with glass dissolution. Mass-balance calculations along flow paths in the lowermost basalt unit in the central part of the plateau, and in the next uppermost unit in the Horse Heaven Hills, support the suggested conceptual model. Results also suggest that the relative importance of controlling phases varies with evolutionary progress and with position within the flow system. 


\section{INTRODUCTION}

The Columbia Plateau aquifer system is located in the Columbia Plateau of central and eastern Washington, north-central and northeastern Oregon, and a smaller part of northwestern Idaho (fig. 1). The aquifer system is the primary source of ground water for domestic, industrial, and municipal uses, and also supplies large quantities of water for agricultural use. Agricultural irrigation withdrawals locally have resulted in water-level declines of more than $150 \mathrm{ft}$. The concurrent use of local and imported surface waters for irrigation within the Columbia Basin Irrigation Project (CBIP; fig. 1) has caused ground-water-level rises of as much as $300 \mathrm{ft}$. These stresses on the system have also resulted in measurable changes in ground-water chemistry that have influenced agricultural practices in some irrigated areas.

The Columbia Plateau aquifer system is one of the regional aquifers selected for study in the U.S. Geological Survey's Regional Aquifer-System Analysis (RASA) Program. The overall RASA program objectives are described in the Foreword. Specifically, the objectives of the Columbia Plateau study are to describe (1) the hydrogeologic framework, (2) the hydrologic characteristics of the aquifer units, (3) the area's water budget, (4) the ground-water and surface-water interaction, and (5) the water-quality characteristics and geochemistry of the aquifer system.

Final results of the Columbia Plateau RASA study are presented in U.S. Geological Survey Professional Paper 1413, Chapter A (Vaccaro, 1996), which summarizes the results of the study, and Chapter B (Whiteman and others, 1994), which presents information on the hydrogeologic framework of the regional aquifer system. This report, although not part of the Professional Paper series, describes and summarizes the ground-water geochemistry part of this RASA study.

\section{Purpose and Scope}

This report describes the spatial variations in water chemistry in the Columbia Plateau aquifer system and discusses plausible reasons for the variations. The variations were determined by examining analyses of ground waters from wells in the plateau that are completed in the basalt aquifers. The wells are in that part of the Columbia Plateau generally bounded by the Columbia River on the north, by the Washington-Idaho border on the east, by the
Blue Mountains on the south, and by the Cascade Range on the west (fig. 1). Areas beyond these approximate bounds are not part of this description.

The scope of the investigation discussed in this report includes the field collection and subsequent chemical analysis of numerous ground-water samples. The data were used to estimate the solute balance in the aquifer system, the mineralogy of the aquifer materials, and mineral-water reactions.

\section{Well-Numbering System}

Wells in Washington and Oregon are identified according to their location in the rectangular system used for the subdivision of public lands (fig. 2). The identification consists of the township number, north or south of the Willamette base line; the range number, east or west of the Willamette meridian; and the section number, numbered consecutively beginning with ' 1 ' in the northeast corner of the township-range, and progressing sinusoidally to ' 36 ' in the southeast corner.

In Washington, a section is further divided into 16 40-acre tracts called quarter-quarter sections. These 40-acre tracts are lettered consecutively (except for 'I' and ' $O$ '), beginning with ' $A$ ' in the northeast corner of the section and progressing sinusoidally to ' $R$ ' in the southeast corner. Within each quarter-quarter section, each well is assigned a unique 2-digit serial number.

In Oregon, a section is divided into 6410 -acre tracts by first dividing the section into four 160 -acre quarter sections, lettered consecutively ' $a$ ' through ' $d$ ', starting in the northeast corner and progressing counterclockwise. Each 160 -acre quarter section is then divided into four 40 -acre quarter-quarter sections. Each quarter-quarter section is further divided into four 10 -acre tracts or quarterquarter-quarter sections, lettered ' $a$ ' through ' $d$ ' in the same manner used for the quarter and quarter-quarter sections. Where two or more wells are in the same 10-acre tract, a unique 2-digit serial number is assigned to each well.

For both States, the letter " $D$ " and a 1-digit sequence number have been added following the serial number to indicate that a well has been deepened. An "S" following the well number indicates the site is a spring. 


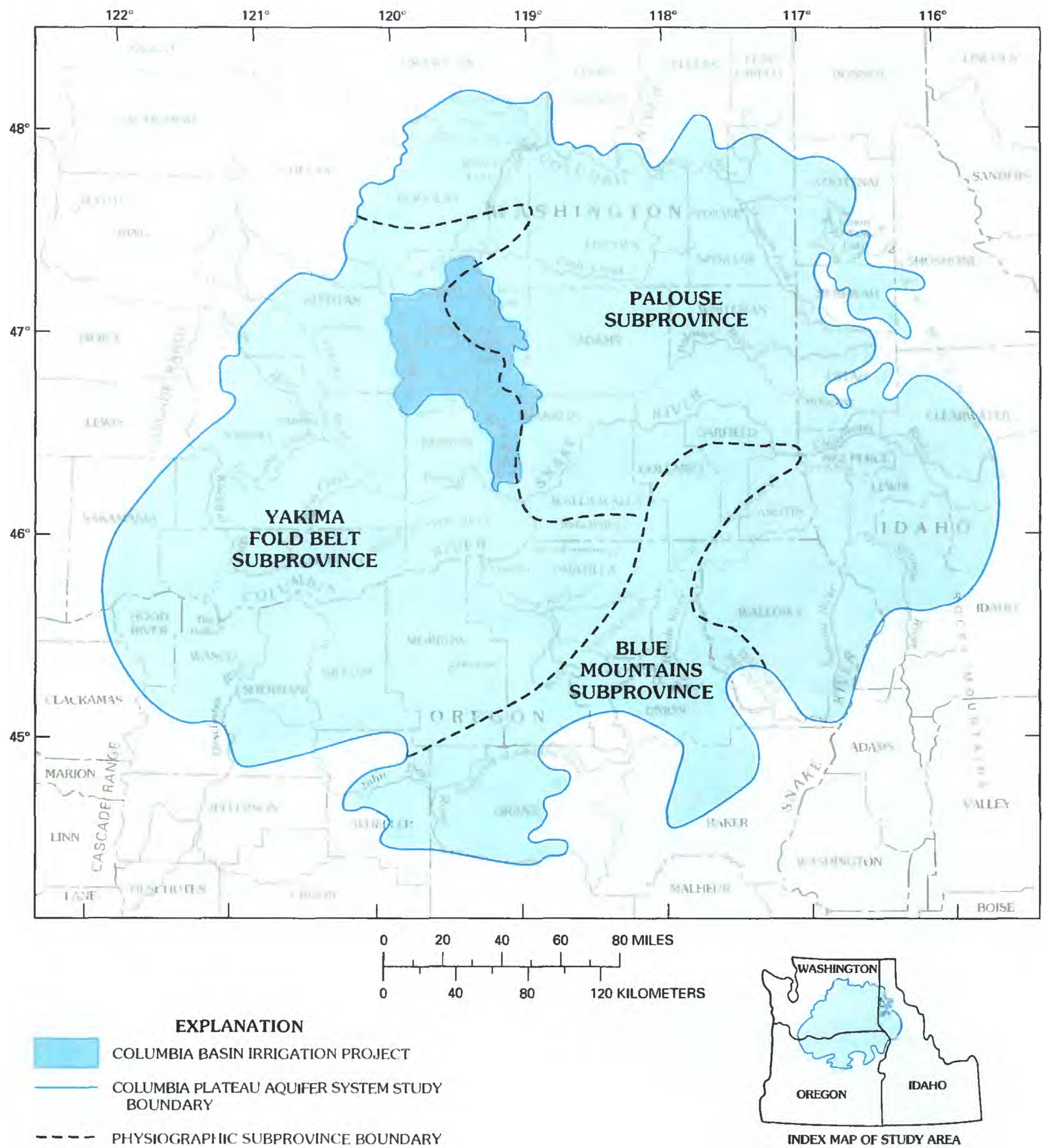

Figure 1.--Location of the Columbia Plateau aquifer system and physiographic subprovince boundaries. 
a. WASHINGTON

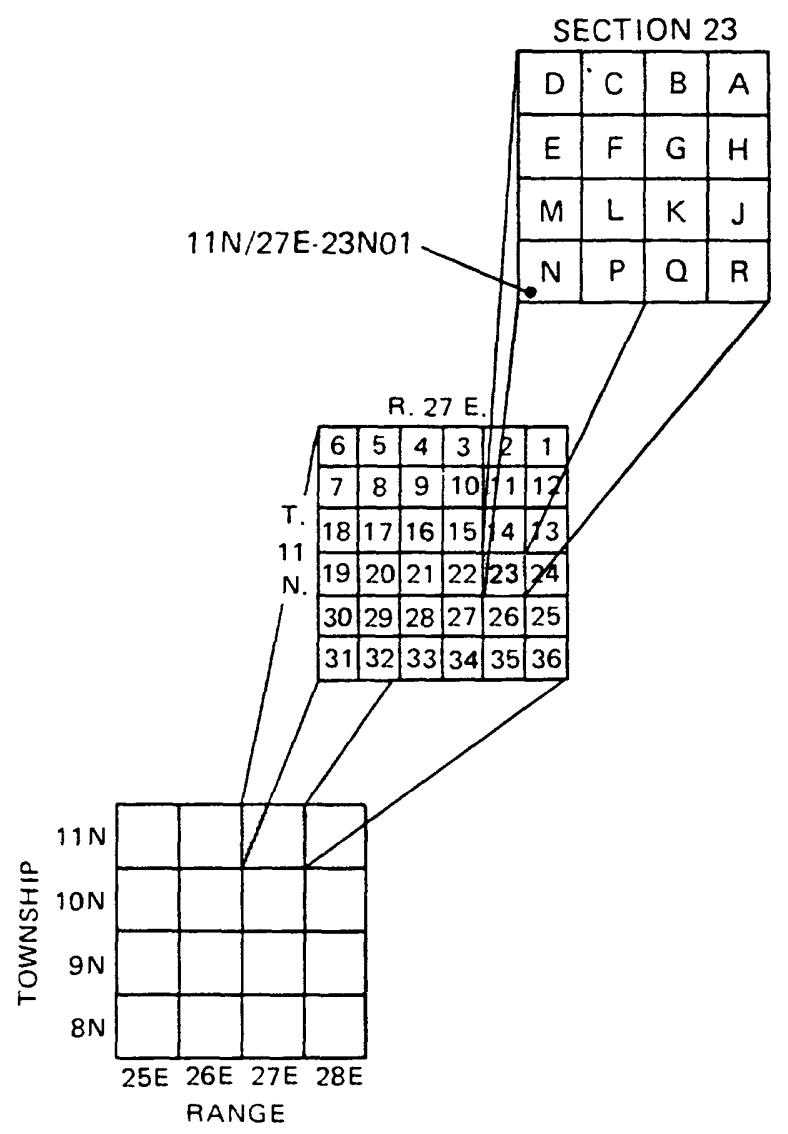

b. OREGON

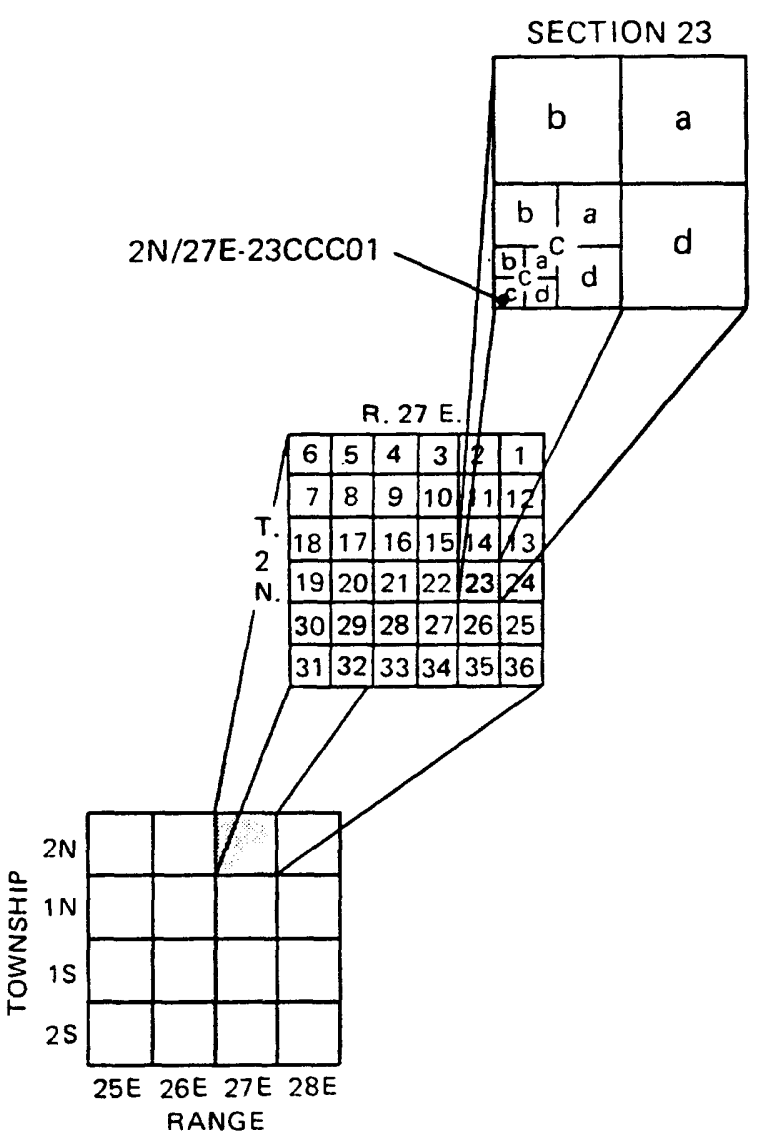

Figure 2.--Well-numbering system. 


\section{DESCRIPTION OF THE STUDY AREA}

The Columbia Plateau is within the Columbia intermontane physiographic province. It is bounded on the west by the Cascade Range, on the north by the Okanogan Highlands, and on the east by the Rocky Mountains. Its southern limit is the mapped extent of the Columbia River Basalt Group. The plateau is drained by the Columbia River and its major tributaries-the Snake, Yakima, John Day, Umatilla, Spokane, Klickitat, and Deschutes Rivers (fig. 1).

Myers and Price (1979) divided the physiographic province into three informal subprovinces: the Yakima Fold Belt, the Blue Mountains, and the Palouse (fig. 1). The Yakima Fold Belt comprises much of the western part of the plateau. It is a region of long, narrow anticlinal ridges and synclinal basins and valleys that generally trend east-west. The Blue Mountains subprovince is an area of high plateaus that are deeply dissected by numerous streams. The subprovince includes the mountains themselves, all of the plateau in Oregon and Washington south and east of the mountains, and folds near Lewiston, Idaho, that represent its extension. The Palouse subprovince is in Washington, north of the Blue Mountains, and extends slightly eastward into Idaho. It slopes gently to the southwest, and includes an area of rolling loess hills.

Southwest of Spokane in eastern Washington are located the "channeled scablands", a large area of northeast-southwest-trending buttes, mesas, and canyons and thick, extensive alluvial gravel, silt, and sand deposits. These features were caused by catastrophic Pleistocene floods that occurred following the breakup of glacial ice dams impounding large lakes in northern Idaho and western Montana. The floodwaters redistributed huge volumes of unconsolidated materials on the plateau, carving the canyons, isolating loess-mantled uplands, and forming steep cliffs, large gravel bars, and current ripple marks 20 to $30 \mathrm{ft}$ high. The thick sedimentary accumulations are in areas where the floodwaters spread, slowed, and ponded.

Most of the plateau is semiarid, receiving less than $15 \mathrm{in} / \mathrm{yr}$ precipitation. Precipitation quantities range from about $6 \mathrm{in} / \mathrm{yr}$ in the central part of the study area to more than $45 \mathrm{in} / \mathrm{yr}$ in the surrounding forested mountains, and tend to increase with altitude and proximity to the Cascade Range and Rocky Mountains. Annual precipitation quantities, together with land-surface altitude, are the most important factors controlling the types, densities, and dis- tributions of natural vegetation. Areas from 350 to about $2,000 \mathrm{ft}$ above sea level receive from 6 to $15 \mathrm{in} / \mathrm{yr}$ precipitation and are dominated by sage and grasses. Areas at intermediate altitudes $(2,000$ to $3,500 \mathrm{ft})$ receive from 15 to $25 \mathrm{in} / \mathrm{yr}$ precipitation and are characterized by both grasslands and forests. Annual precipitation in areas higher than $3,500 \mathrm{ft}$ can exceed $45 \mathrm{in} / \mathrm{yr}$; these areas are primarily forest lands.

\section{Geologic Framework}

The Columbia Plateau is both a structural and a stratigraphic basin with its lowest point near Pasco, Washington (fig. 1). It is underlain by the basalts of the Columbia River Basalt Group of Miocene age, which are variably interlayered with and overlain by generally thin and discontinuous Miocene sediments. Most of the interbedded sediments belong to the Ellensburg Formation of Miocene age.

The basalts and sediments are overlain by a discontinuous mantle of sediments of Miocene to Holocene age, collectively named the overburden in this study. The overburden includes fluvial consolidated to unconsolidated deposits of lacustrine, volcanic, and eolian origin, which are lithologically diverse. Major units composing the overburden are the Dalles Group and the Ellensburg, Latah, Ringold, and Palouse Formations of Tertiary age. The thickest deposits occur in structural basins adjacent to the Cascade Range.

The Columbia River Basalt Group underlies an area of about $63,200 \mathrm{mi}^{2}$, including most of eastern Washington, much of northern Oregon, and parts of west-central Idaho (Tolan and others, 1987); about $51,000 \mathrm{mi}^{2}$ are within the study area (fig. 3). The rocks are tholeiitic flood basalts, primarily flat-lying in much of the plateau. Pre-eruption topography and folding and faulting in the Yakima Fold Belt were the cause of the more complex topography and geologic structure in that part of the study area. The basalts are underlain by Precambrian to lower-Tertiary metamorphic and volcanic rocks along the borders of the plateau. In the interior of the plateau, the basalts are underlain by marine and (or) continental sediments and in the southwestern part of the study area, by granitic rocks in the east and by volcanic predecessors of the present Cascade Range in the west. 


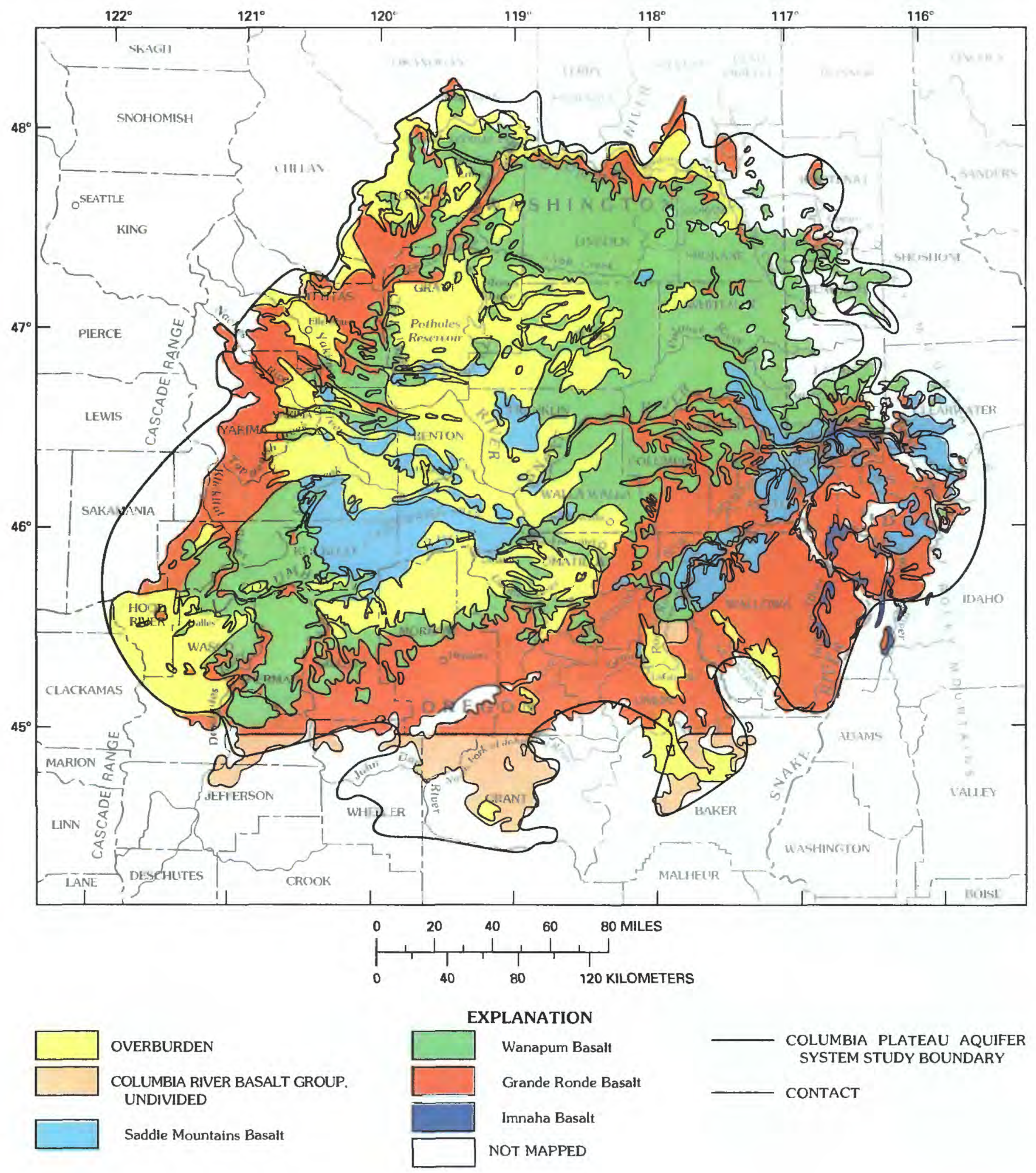

Figure 3.--Generalized extent of the Columbia River Basalt Group within the study area. 


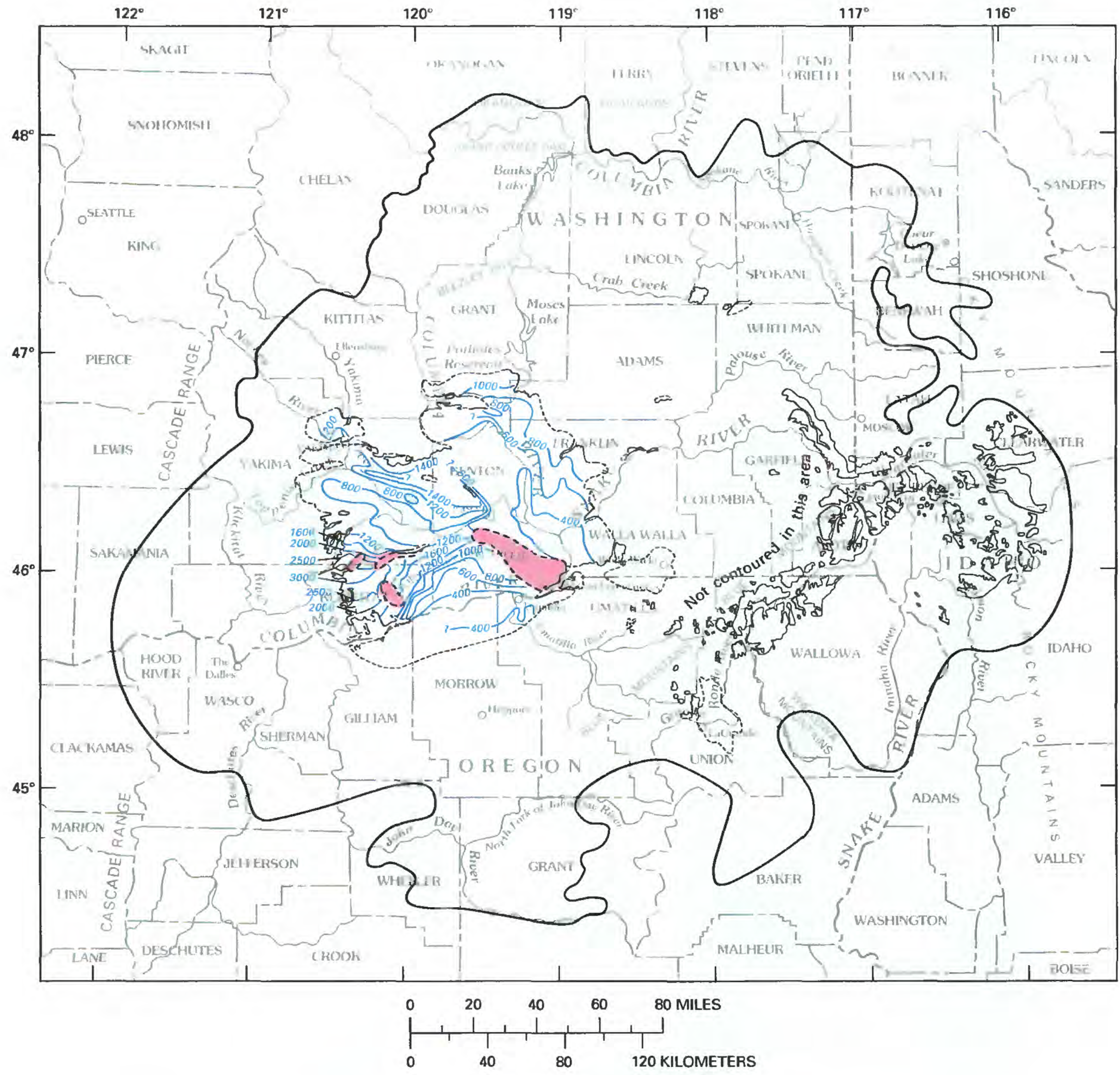

EXPLANATION

AREA WHERE SADDLE MOUNTAINS UNIT IS UNSATURATED

COLUMBIA PLATEAU AQUIFER SYSTEM STUDY BOUNDARY

- 400 - WATER-LEVEL CONTOUR-Shows approximate alti1ude of water level. Queried where uncerlain. Hachures indicate depression. Contour interval. in feet, is variable Datum is sea level

— APPROXIMATE LIMIT OF SADDLE MOUNTAINS BASALT—Dashed where inferred

Figure 5.--Potentiometric surface of the Saddle Mountains unit, spring 1985. From Whiteman and others (1994). 


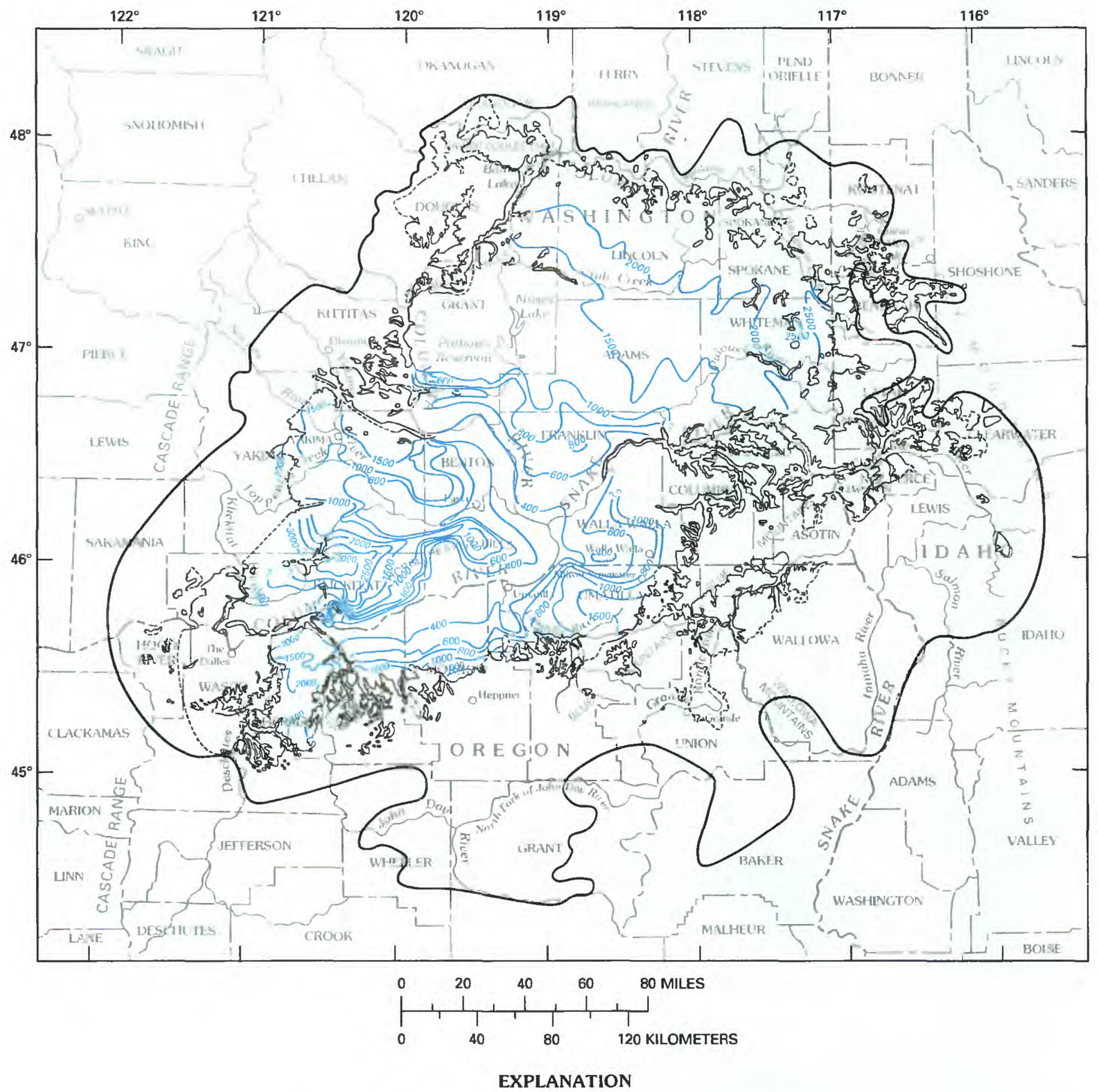

COLUMBIA PLATEAU AQUIFER SYSTEM STUDY BOUNDARY

WATER-LEVEL CONTOUR-Shows approximate altitude of water level. Queried where uncertain. Hachures indicate depression.

Contour interval, in feet. is variable. Datum is sea level

APPROXIMATE LIMIT OF WANAPUM UNIT-Dashed where inferred

Figure 6.--Potentiometric surface of the Wanapum unit, spring 1985. From Whiteman and others (1994). 


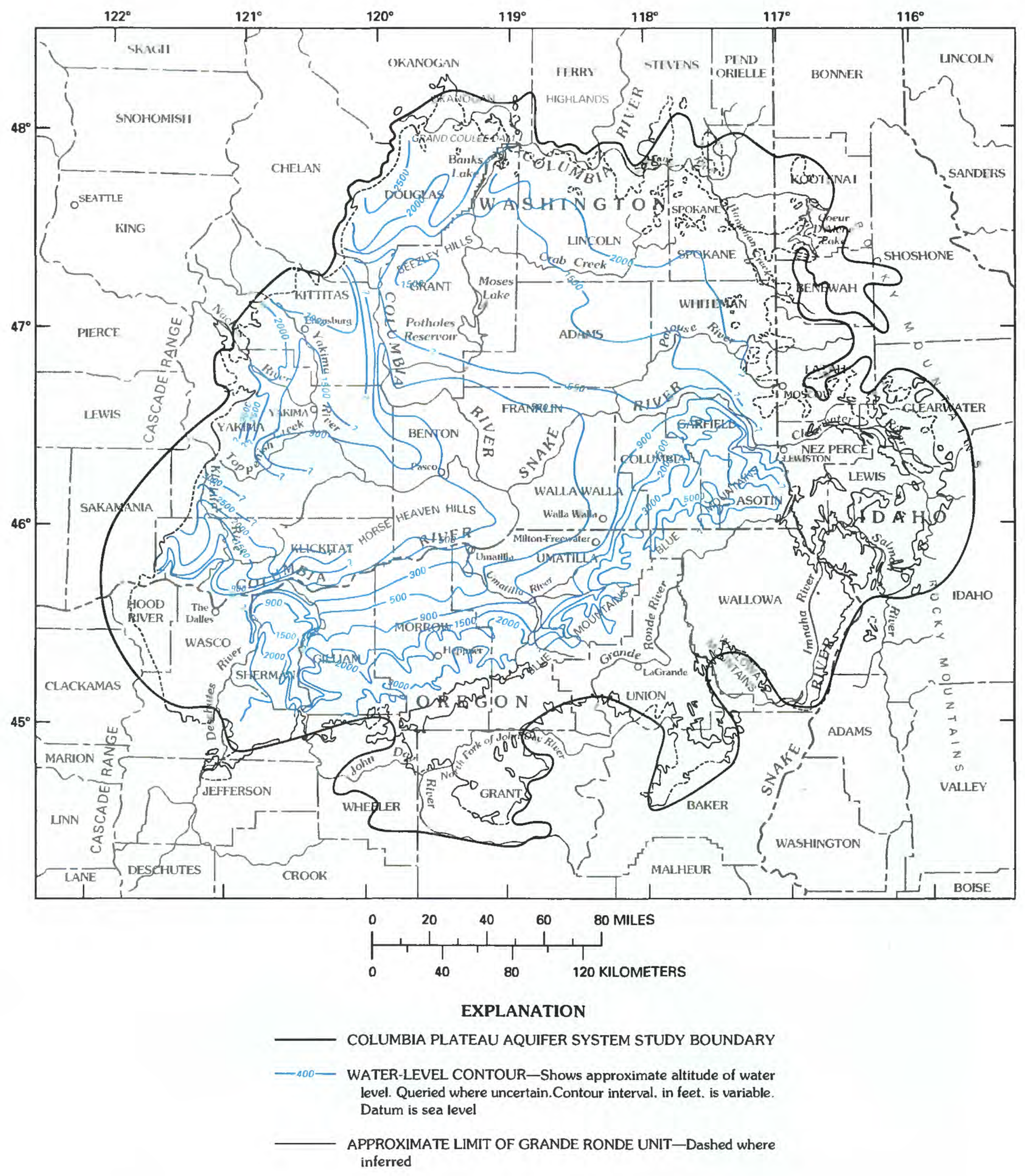

Figure 7.--Potentiometric surface of the Grande Ronde unit, spring 1985. From Whiteman and others (1994). 
The Columbia River Basalt Group lavas issued largely from a system of northwest-southeast-trending linear fissures in the southeastern part of the plateau (Hooper, 1982). Eruption began about 16.9 million years ago and lasted for about 10.5 million years. Initial eruptions lasted about 500,000 years and occurred in Idaho and Oregon in the general area of the basalt's southeastern most extent. Subsequent eruptions occurred primarily farther north, in the general area of the intersection of the Idaho, Oregon, and Washington State lines. Although eruptions continued intermittently for about 10 million years, nearly 90 percent of the present volume of basalt was emplaced during a period from about 16.5 to 14.5 million years ago. The fluid nature of the lavas, together with the large volumes erupted, the relatively flat pre-eruption topography, and ongoing uplift in the vent region, resulted in the extensive areal coverage of the Columbia River Basalt Group. The average thickness of the entire basalt sequence is more than $1 / 2$ mile, and its volume has been estimated at nearly $40,000 \mathrm{mi}^{3}$ (Tolan and others, 1987).

Swanson and others (1979) stratigraphically divided the Columbia River Basalt Group into 1 subgroup, 5 formations, and 14 members (fig. 4). The Imnaha and Picture Gorge Basalts are the lowermost formations in the group and are known to occur only at several locations in the southern and southeastern parts of the plateau. They were not addressed separately in this study because of their limited extent and their occurrence only at the edge of the study area; they have been combined with other basalt formations. The Yakima Basalt Subgroup is the most extensive and hydrogeologically important part of the aquifer system. The subgroup comprises the remaining three formations - the Grande Ronde, Wanapum, and Saddle Mountains Basalts.

The Grande Ronde Basalt underlies nearly all of the study area and comprises nearly 90 percent of the volume of the subroup (see fig. 3). It is exposed along the southern, southeastern, and northern margins of the plateau and in a few deeply incised valleys in the central and southwestern parts of the study area. Its thickness ranges from a few feet, where it lapped against older rocks, to more than 4,000 ft in the Pasco Basin. The Grande Ronde Basalt comprises about 130 individual flows (Tolan and others, 1987) and contains a few thin sedimentary interbeds. Interbedded sediments range from clay to gravel size, depending on proximity to source areas.

The Grande Ronde Basalt is overlain throughout much of its extent by the Vantage Member of the Ellensburg Formation, a nearly ubiquitous claystone to siltstone averaging about $25 \mathrm{ft}$ thick. The Vantage Member is largely absent in the southeastern part of the study area. In the northeastern part of the plateau, the interbed in the same stratigraphic position is assigned to the Latah Formation (Swanson and others, 1979). To avoid nomenclature problems in this RASA study, major interbeds between basalt formations are identified relative to their stratigraphic position. This general unit (fig. 4) is therefore called the Wanapum-Grande Ronde interbed (Drost and others, 1990).

The Wanapum Basalt is slightly less extensive than the Grande Ronde Basalt and also underlies most of the study area (fig. 3). Its flows were emplaced over a period of less than 1 million years, following the hiatus during which the Wanapum-Grande Ronde interbed was deposited. In the northern half of the study area, the Wanapum Basalt is exposed or is covered by a veneer of sediments. In the southern half it is largely covered by thick sedimentary sequences or by the Saddle Mountains Basalt. The Wanapum Basalt averages about $400 \mathrm{ft}$ in thickness, ranging from a few feet where it pinches out against the Grande Ronde Basalt to more than 1,000 ft in the southwestern part of the study area. It comprises about 33 flows (Tolan and others, 1987) and accounts for less than 10 percent of the volume of the Columbia River Basalt Group. Interbeds are relatively rare in the Wanapum Basalt, although they are more common than in the Grande Ronde Basalt. They generally are thin and of limited lateral extent. The Wanapum Basalt is overlain, primarily in the southwestern part of the study area, by the Saddle Mountains-Wanapum interbed (Drost and others, 1990). This interbed averages about $50 \mathrm{ft}$ in thickness and locally is as thick as $200 \mathrm{ft}$.

The Saddle Mountains Basalt is the youngest formation in the Columbia River Basalt Group and is present only in the central and southwestern parts of the study area (fig. 3). It erupted over a period of more than 7.5 million years, but forms less than 1 percent of the volume of the group. It has an average thickness of about $400 \mathrm{ft}$ and locally is more than $800 \mathrm{ft}$ thick. Sedimentary interbeds are common in the Saddle Mountains Basalt and are commonly thicker than $50 \mathrm{ft}$. This increased frequency of interbeds, together with the unconformable contacts of most Saddle Mountains Basalt flows, results from the long intervals between eruptions. 


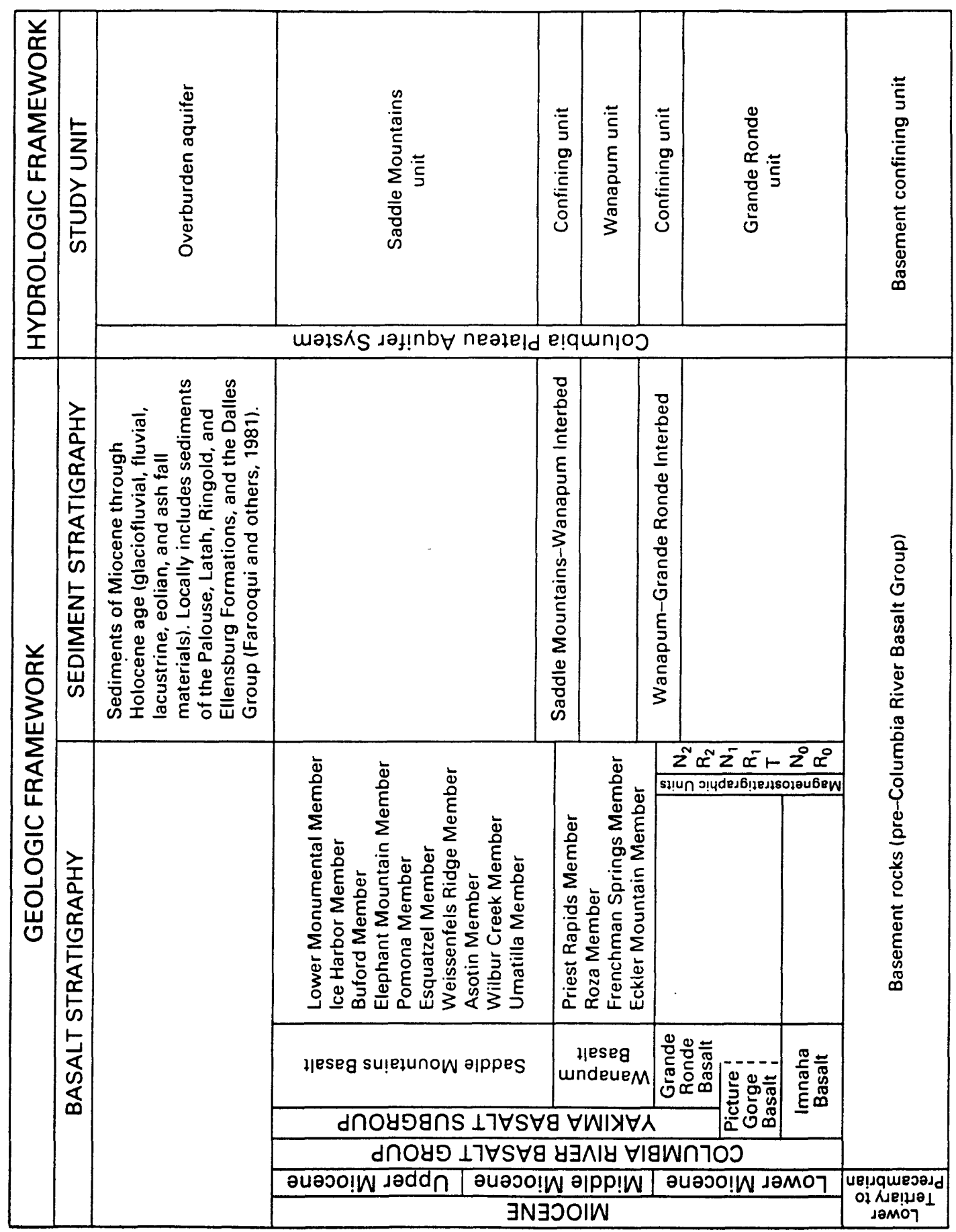

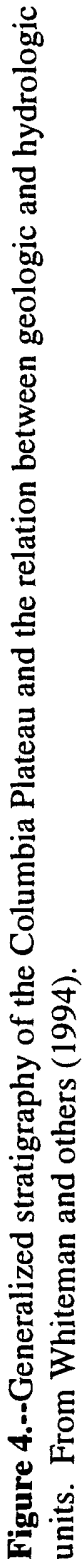




\section{Mineralogy}

The rocks of the Columbia River Basalt Group are tholeiitic basalts. Fresh, unaltered samples consist primarily of volcanic glass with an essentially rhyolitic composition (table 1). The remaining major components are plagioclase feldspar (labradorite), pyroxene (augite to sub-calcic augite), and titanium-iron oxides of the ilmenite magnetic solid solution series (Ames, 1980). Labradorite generally is the most abundant crystalline phase, commonly occurring as microscopic laths surrounded by smaller and less numerous pyroxene grains. Accessory minerals, in varying relative amounts, include apatite, olivine, and metallic sulfides. All of these minerals occur in a cryptocrystalline to glassy matrix. The relative abundances of crystalline and amorphous phases vary with location in an individual basalt flow. Dense interior sections that cooled more slowly tend to be less glassy and more crystalline.

Water-rock interactions after basalt emplacement have resulted in the formation of secondary mineral phases in and adjacent to interstitial spaces. Benson and Teague (1982) and Ames (1980) observed in six deep cores from the Hanford Reservation in Washington that the secondary suite commonly coating fracture surfaces differed from that found in vesicles both qualitatively and quantitatively for samples from as deep as $5,000 \mathrm{ft}$. They found that fractures generally contained smectite, clinoptilolite, and silica, with minor amounts of illite, pyrite, and calcite. Some vesicles were found to contain minor amounts of other minerals, including chabazite, erionite, phillipsite, analcime, apatite, gypsum, and vermiculite; these probably are primary mineral phases that formed in some vesicles as the basalts cooled. Fractures tended to be filled with alteration products, whereas vesicles were commonly only partially filled. Hearn and others (1985) suggested that the alteration products identified in 25 basalt samples from five sites on the plateau - primarily nontronitic smectite, clinoptilolite, silica phases, and amorphous iron oxyhydroxides-formed at temperatures below $100^{\circ} \mathrm{C}$.

\section{Hydrogeology}

The hydrogeology of the Columbia Plateau aquifer system is thoroughly described in the following reports: Bauer and Hansen (in press), Whiteman and others (1994), Hansen and others (1994), Bauer and Vaccaro (1990), Cline and Knadle (1990), Drost and others (1990), Gonthier (1989), Lane and Whiteman (1989), Nelson (1991), Davies-Smith and others (1988), Lane (1988a, 1988b),
Lindholm and Vaccaro (1988), Collins (1987), Drost and Whiteman (1986), Vaccaro (1986), Whiteman (1986), Bauer and others (1985), Cline (1984), Prych (1983), Tanaka and others $(1974,1979)$, Mundorff and others (1977), MacNish and Barker (1976), Luzier and Skrivan (1975), LaSala and Doty (1971), Newcomb (1961, 1965, 1969), and Luzier and others (1968). Readers are referred to these reports for a more detailed discussion of the hydrogeology of the aquifer system.

The hydrogeologic framework developed for the study area divides the aquifer system into seven units-the overburden aquifer, three basalt aquifer units, two confining units, and the basement confining unit (fig. 4). The three formations within the Yakima Basalt Subgroup-the Saddle Mountains, Wanapum, and Grande Ronde Basalts-and their intercalated sediments are used to describe the basalts within the conceptual hydrogeologic model constructed. In the southeastern part of the study area, the Imnaha Basalt is included with the Grande Ronde Basalt. The term "unit" is used in this study to distinguish the basalt aquifer units from basalt formations. The confining units are equivalent to the Saddle MountainsWanapum and Wanapum-Grande Ronde interbeds. The pre-basalt "basement" rocks generally have much lower permeabilities than the basalts and are considered to be the base of the regional flow system; they are named the basement confining unit.

Ground water in the basalts is found in joints, vesicles, fractures, and intraflow structures that create permeable zones in the rocks. The most permeable parts of individual basalt flows are the upper sections, known as flow tops. These zones tend to be incoherent, rubbly, and vesicular brecciated sections that transmit water readily. Flow bases generally have similar characteristics and tend to be the next most permeable parts of individual flows. The superposition of these sections defines an interflow zone; this is the most transmissive part of a basalt section. Secondary permeability within the more coherent and dense colonnade and entablature parts of basalt flows, which separate interflow zones, develops by differential contraction during post-emplacement cooling and results in characteristic jointing and fracturing. Permeability also can be locally increased by folding and faulting, although faulting can locally decrease hydraulic continuity by juxtaposing interflow zones and less-permeable zones (Newcomb, 1961). Although interbeds are considered to be confining units in the regional aquifer system, they function locally as aquifer units where their lithology and extent facilitate the storage and transmission of significant quantities of water. 
Table 1.--Compositions and formulas of basaltic glass, smectite, and clinoptilolite from the Columbia River Basalt Group

Average of 33 basaltic glass analyses from samples of Grande Ronde Basalt pillow rinds and dike selvages

(Wright and others, 1979). Titanium data note included.

Mean composition, normalized to 100 weight percent.

$\begin{array}{lr}\mathrm{SiO}_{2} & 56.63 \\ \mathrm{Al}_{2} \mathrm{O}_{3} & 14.13 \\ \mathrm{FeO} & 12.57 \\ \mathrm{MgO} & 4.17 \\ \mathrm{CaO} & 8.49 \\ \mathrm{Na}_{2} \mathrm{O} & 2.78 \\ \mathrm{~K}_{2} \mathrm{O} & 1.23\end{array}$

Calculated formula, assuming 6 oxygens per formula weight.

$$
\mathrm{Fe}_{0.365} \mathrm{Mg}_{0.216}{ }^{\mathrm{Ca}} 0.316^{\mathrm{Na}}{ }_{0.187} \mathrm{~K}_{0.055}{ }^{\mathrm{Al}}{ }_{0.579} \mathrm{Si}_{1.968} \mathrm{O}_{6}
$$

Average of 40 smectite analyses (Hearn and others, 1985, p. 20)

Mean composition, normalized to 100 weight percent.

$\begin{array}{lr}\mathrm{SiO}_{2} & 62.5 \\ \mathrm{Al}_{2} \mathrm{O}_{3} & 11.4 \\ \mathrm{FeO} & 12.6 \\ \mathrm{MgO} & 9.4 \\ \mathrm{CaO} & 1.7 \\ \mathrm{Na}_{2} \mathrm{O} & 1.5 \\ \mathrm{~K}_{2} \mathrm{O} & 0.9\end{array}$

Calculated formula, assuming 4 tetrahedral sites and 11 oxygen equivalents per unit cell.

Calculation is from Ross and Hendricks (1946, p. 41-42)

$$
\mathrm{Ca}_{0.113}{ }^{\mathrm{Na}} 0.180 \mathrm{~K}_{0.071}\left(\mathrm{Al}_{0.713} \mathrm{Fe}_{0.588} \mathrm{Mg}_{0.870}\right)\left(\mathrm{Al}_{0.121} \mathrm{Si}_{3.88}\right) \mathrm{O}_{10}(\mathrm{OH})_{2}
$$

Average of 30 clinoptilolite analyses (Hearn and others, 1985, p. 20).

Mean composition, normalized to 100 weight percent.

$\begin{array}{lr}\mathrm{SiO}_{2} & 72.8 \\ \mathrm{Al}_{2} \mathrm{O}_{3} & 16.4 \\ \mathrm{FeO} & 0.5 \\ \mathrm{MgO} & 0.4 \\ \mathrm{CaO} & 1.6 \\ \mathrm{Na}_{2} \mathrm{O} & 5.6 \\ \mathrm{~K}_{2} \mathrm{O} & 2.7\end{array}$

Calculated formula, assuming 36 oxygens per unit cell.

$$
\mathrm{Ca}_{0.48}{ }^{\mathrm{Na}}{ }_{0.88} \mathrm{~K}_{0.94} \mathrm{Al}_{3.0} \mathrm{Fe}_{0.20} \mathrm{Mg}_{0.10}\left(\mathrm{Al}_{0.66} \mathrm{Si}_{1.34}\right) \mathrm{Si}_{13} \mathrm{O}_{36}
$$


The basalt units are naturally recharged where they are exposed at the surface. The locally large permeabilities of the basalts allow rapid recharge by precipitation and snowmelt. Bauer and Vaccaro (1990) estimated that natural recharge for 53 basins on the plateau ranges from 0.0 to $45 \mathrm{in} / \mathrm{yr}$, with a median of $0.56 \mathrm{in} / \mathrm{yr}$. They found a general relation between annual precipitation, soil type, and plant community, and they observed that agricultural practices have increased natural recharge by as much as $40 \mathrm{in} /$ $\mathrm{yr}$ in areas irrigated with surface water. Similarly, natural recharge has been augmented in areas irrigated with ground-water pumpage and in areas alternating dry-land farming practices with fallow years. Recharge to the aquifer system was estimated to have been about $6,000 \mathrm{ft}^{3} / \mathrm{s}$ under natural conditions and about $10,000 \mathrm{ft}^{3} / \mathrm{s}$ under current (1980's) conditions.

Ground water in the Columbia Plateau flows primarily from areas of higher altitudes toward topographically lower surface drainage features, such as the Columbia and Snake Rivers. The direction of flow also is influenced by the distribution of recharge, geologic structure, the geometry of the aquifer system, overburden thickness, lithology and extent, the hydraulic characteristics of the rock materials, and ground-water pumping (Whiteman and others, 1994).

The direction of ground-water flow between the three basalt units is downward over most of the plateau, from the Saddle Mountains unit to the Wanapum unit and from the Wanapum unit to the Grande Ronde unit. Flow is upward from or within the Grande Ronde unit in the vicinity of major streams and lakes. Although flow between units is downward over much of the plateau, ground water in the basalts tends to become more confined with increasing depth in the system, and combinations of several basalt flows can often be considered a discrete aquifer unit. Figures 5 to 7 show potentiometric surfaces for the three basalt units; the maps indicate that the flow directions are similar in most locations.

Agricultural pumping has significantly affected the regional flow, particularly in the central part of the plateau east of the CBIP. Ground-water withdrawals have caused 150- to 300 -foot declines in water levels in this area (Cline, 1984) and locally may have reduced the natural downward vertical gradient. Numerous uncased wells in the study area allow ground water to move rapidly between units and beyond intervening less-permeable zones. The magnitude of this flux is a function of head difference(s) between the zones connected by the well bores and is locally at least an order of magnitude larger than the natural vertical fluxes (Hansen and others, 1994).

\section{DATA COMPILATION}

The hydrochemical data used in this study consist of 537 analyses of samples from 237 sites from summer 1982 through spring 1984. Most of the data were collected as part of an investigation of the spatial variability of dissolved sodium concentrations in the basalt aquifers of the Columbia Plateau in Washington, the relation of this variability to ground-water flow, and the geochemical factors controlling sodium levels (Bortleson and Cox, 1985; Hearn and others, 1985; and Steinkampf and others, 1985). Oregon data were collected as part of this RASA study. All hydrochemical data collected on the Columbia Plateau between 1982 and 1985 were published as part of this RASA study by Wagner and Lane (1994). The data used in this investigation derive from samples from wells for which the hydrogeology of the completion intervals have been described; the producing units therefore are known.

Water samples and field data were collected from pumping wells after the temperature of the discharge stream had stabilized. Values of $\mathrm{pH}$, dissolved oxygen, specific conductance, temperature, and dissolved bicarbonate and carbonate were determined at each field site prior to sample collection. Samples were analyzed for dissolved inorganic constituents by the U.S. Geological Survey National Water-Quality Laboratory. Unaerated, field-precipitated samples from selected sites were sent to the University of Arizona Isotope Geochemistry Laboratory for radiocarbon analyses. Ratios of the stable isotopes of hydrogen, carbon, and oxygen were determined in samples from selected radiocarbon sample sites by the U.S. Geological Survey Reston Stable Isotope Laboratory.

The resulting data base comprised more than 1,200 analyses from more than 425 wells. Records of field conditions under which the samples were collected were examined to identify those samples likely to best represent the ground-water chemistry, and 821 analyses representing 288 sites were identified. Fifty-one of these sites were not included for analysis because the wells were open to more than one hydrogeologic unit. The data have been described in Steinkampf (1989) and are summarized in table 2. 
Table 2.-- Summary of selected hydrochemical data for ground water in three basalt hydrogeologic units

[Values in milligrams per liter $(\mathrm{mg} / \mathrm{L})$ unless otherwise indicated; ${ }^{\circ} \mathrm{C}$, degree Celsius; $\mu \mathrm{S} / \mathrm{cm}$, microsiemens per centimeter; $\mu \mathrm{g} / \mathrm{L}$, micrograms per liter; pmc, percent modern carbon]

\begin{tabular}{|c|c|c|c|c|}
\hline Hydrochemical property & Maximum & Mean & Minimum & $\begin{array}{l}\text { Number } \\
\text { of } \\
\text { analyses }\end{array}$ \\
\hline \multicolumn{5}{|c|}{ Saddle Mountains unit } \\
\hline Specific conductance $(\mu \mathrm{S} / \mathrm{cm})$ & 1,100 & 579 & 225 & 22 \\
\hline Temperature $\left({ }^{\circ} \mathrm{C}\right)$ & 22 & 17 & 8.6 & 21 \\
\hline pH (standard units) & 8.6 & 7.79 & 7 & 22 \\
\hline Calcium (Ca) & 98 & 46 & 1.9 & 22 \\
\hline Magnesium (Mg) & 62 & 26.5 & 0.28 & 22 \\
\hline Sodium $(\mathrm{Na})$ & 100 & 31.1 & 12 & 22 \\
\hline Potassium (K) & 13 & 6.6 & 1.5 & 22 \\
\hline Chloride $(\mathrm{Cl})$ & 120 & 31.6 & 3.4 & 22 \\
\hline Sulfate $\left(\mathrm{SO}_{4}\right)$ & 200 & 76.1 & 0.6 & 22 \\
\hline Bicarbonate $\left(\mathrm{HCO}_{3}\right)$ & 345 & 203 & 121 & 22 \\
\hline Carbonate $\left(\mathrm{CO}_{3}\right)$ & 0.0 & 0.0 & 0.0 & 22 \\
\hline Fluoride $(\mathrm{F})$ & 1.4 & 0.5 & 0.2 & 22 \\
\hline Nitrogen $\left(\mathrm{NO}_{2}+\mathrm{NO}_{3}\right.$, as $\left.\mathrm{N}\right)$ & 14 & 4.78 & 0.1 & 22 \\
\hline Silicon $\left(\mathrm{SiO}_{2-}\right)$ & 71 & 55.1 & 36 & 22 \\
\hline Iron $(\mathrm{Fe})(\mu \mathrm{g} / \mathrm{L})$ & 72 & 11 & 3 & 22 \\
\hline Manganese $(\mathrm{Mn})(\mu \mathrm{g} / \mathrm{L})$ & 72 & 7 & 1 & 22 \\
\hline Dissolved oxygen ((DO) & 10 & 6.39 & 0.5 & 20 \\
\hline$\delta^{18} \mathrm{O}$ & -18 & -18 & -18 & 1 \\
\hline$\delta^{2} \mathrm{H}$ & -144 & -144 & -144 & 1 \\
\hline$\delta^{13} \mathrm{C}$ & -9.9 & -9.9 & -9.9 & 1 \\
\hline${ }^{14} \mathrm{C}(\mathrm{pmc})$ & 40.2 & 40.2 & 40.2 & 1 \\
\hline Sum of dissolved constituents & 620 & 383 & 160 & 21 \\
\hline \multicolumn{5}{|c|}{ Wanapum unit } \\
\hline Specific conductance $(\mu \mathrm{S} / \mathrm{cm})$ & 1,970 & 420 & 159 & 311 \\
\hline Temperature $\left({ }^{\circ} \mathrm{C}\right)$ & 24.5 & 14.4 & 6.2 & 310 \\
\hline pH (standard units) & 9.4 & 7.64 & 6.1 & 312 \\
\hline Calcium (Ca) & 180 & 35.3 & 1.1 & 312 \\
\hline Magnesium (Mg) & 75 & 15.9 & 0.06 & 312 \\
\hline Sodium $(\mathrm{Na})$ & 130 & 27.6 & 5 & 312 \\
\hline Potassium (K) & 22 & 4.5 & 0.9 & 312 \\
\hline Chloride $(\mathrm{Cl})$ & 300 & 19.5 & 1.1 & 312 \\
\hline Sulfate $\left(\mathrm{SO}_{4}\right)$ & 290 & 32.8 & 0.3 & 312 \\
\hline Bicarbonate $\left(\mathrm{HCO}_{3}\right)$ & 406 & 177 & 53 & 312 \\
\hline Carbonate $\left(\mathrm{CO}_{3}\right)^{1}$ & 21 & 12.3 & 6 & 4 \\
\hline Fluoride $(\mathrm{F})$ & 3.4 & 0.43 & 0.1 & 312 \\
\hline Nitrogen $\left(\mathrm{NO}_{2}+\mathrm{NO}_{3}\right.$, as $\left.\mathrm{N}\right)$ & 35 & 4.37 & 0.1 & 304 \\
\hline Silicon $\left(\mathrm{SiO}_{2}\right)$ & 72 & 46.5 & 5.8 & 312 \\
\hline Iron $(\mathrm{Fe})(\mu \mathrm{g} / \mathrm{L})$ & 1,100 & 24 & 3 & 312 \\
\hline Manganese $(\mathrm{Mn})(\mu \mathrm{g} / \mathrm{L})$ & 890 & 21 & 1 & 312 \\
\hline Dissolved oxygen (DO) & 10.6 & 5.5 & 0.1 & 266 \\
\hline$\delta^{18} \mathrm{o}$ & -15 & -16.7 & -19 & 23 \\
\hline$\delta^{2} \mathrm{H}$ & -121 & -13.8 & -148 & 13 \\
\hline$\delta_{14}^{13} \mathrm{C}$ & -26.7 & -13.8 & -7.7 & 31 \\
\hline${ }^{14} \mathrm{C} \quad(\mathrm{pmc})$ & 118.8 & 48.3 & 4.6 & 27 \\
\hline Sum of dissolved materials & 1,100 & 275 & 130 & 295 \\
\hline
\end{tabular}


Table 2.-- Summary of selected hydrochemical data for three basalt hydrogeologic units--Continued

\begin{tabular}{|c|c|c|c|c|}
\hline Hydrochemical property & Maximum & Mean & Minimum & $\begin{array}{l}\text { Number } \\
\text { of } \\
\text { analyses }\end{array}$ \\
\hline \multicolumn{5}{|c|}{ Grande Ronde unit } \\
\hline Specific conductance $(\mu \mathrm{S} / \mathrm{cm})$ & 830 & 311.7 & 119 & 203 \\
\hline Temperature $\left({ }^{\circ} \mathrm{C}\right)$ & 36.7 & 18.3 & 7.6 & 202 \\
\hline pH (standard units) & 9.4 & 7.89 & 6.7 & 202 \\
\hline Calcium (Ca) & 88 & 22.9 & 0.95 & 203 \\
\hline Magnesium (Mg) & 33 & 10.3 & 0.01 & 203 \\
\hline Sodium $(\mathrm{Na})$ & 90 & 27.7 & 4.1 & 203 \\
\hline Potassium (K) & 13 & 4.9 & 1.1 & 203 \\
\hline Chloride $(\mathrm{Cl})$ & 45 & 6.9 & 0.8 & 203 \\
\hline Sulfate $\left(\mathrm{SO}_{4}\right)$ & 96 & 14.0 & 0.2 & 203 \\
\hline Bicarbonate $\left(\mathrm{HCO}_{3}\right)$ & 339 & 169.9 & 42 & 203 \\
\hline Carbonate $\left(\mathrm{CO}_{3}\right)^{1}$ & 56 & 18.7 & 2 & 20 \\
\hline Fluoride $(F)$ & 4.9 & 0.69 & 0.1 & 203 \\
\hline Nitrogen $\left(\mathrm{NO}_{2}+\mathrm{NO}_{3}\right.$, as $\left.\mathrm{N}\right)$ & 7.3 & 0.68 & 0.1 & 203 \\
\hline Silicon $\left(\mathrm{SiO}_{2}\right)$ & 110 & 57.2 & 29 & 203 \\
\hline $\operatorname{lron}(\mathrm{Fe})(\mu \mathrm{g} / \mathrm{L})$ & 760 & 51 & 3 & 203 \\
\hline Manganese $(\mathrm{Mn})(\mu \mathrm{g} / \mathrm{L})$ & 810 & 15 & 1 & 203 \\
\hline Dissolved oxygen (DO) & 10.2 & 2.6 & 0.1 & 160 \\
\hline$\delta^{18} \mathrm{O}$ & -16.7 & -17.7 & -19 & 16 \\
\hline$\delta^{2} \mathrm{H}$ & -134 & -142 & -147 & 9 \\
\hline$\delta^{13} \mathrm{C}$ & -10.7 & -14.1 & -19.4 & 20 \\
\hline${ }^{14} \mathrm{C}(\mathrm{pmc})$ & 87.4 & 27.3 & 3.4 & 20 \\
\hline Sum of dissolved constituents & 510 & 235 & 94 & 183 \\
\hline
\end{tabular}

${ }^{\mathrm{I}}$ Data presented for non-zero values only

Most of the discussion in this report is based on data from the Horse Heaven Hills area in south-central Washington (see fig. 15 and tables 3 and 4 ) and is limited mostly to data from the Grande Ronde unit. Spatial variations in both relative and absolute concentrations of major hydrochemical components in the basalt units depend on the interrelation of many factors, such as water-rock chemical interactions, location within the aquifer system, and in some areas land use, within the ground-water flow system. The extent to which compositional variations can be related to these factors depends in part on the amount of information available about the flow system and on the reliability of the description of ground-water movement. The Horse Heaven Hills is a relatively small area for which the hydrogeologic framework and flow path have been described in sufficient detail to allow discussion of spatial hydrochemical changes in the local flow system (Packard and others, U.S. Geological Survey, written commun., 1984). The Horse Heaven Hills data were collected in April 1984 as part of the study by Hearn and others (1985) and were included in the data set used by Steinkampf and others (1985). The data were obtained from wells completed in the Wanapum unit. 
Table 3.-- Selected mole ratios in basaltic glass and ground waters in the Horse Heaven Hills, Washington

[Site locations are shown on figure $15 ; \mathrm{K}$, potassium; $\mathrm{Na}$, Sodium; $\mathrm{Ca}$, calcium; $\mathrm{Mg}$, magnesium]

\begin{tabular}{ccccccccc}
\hline & & \multicolumn{7}{c}{ Horse Heaven Hill sites } \\
\cline { 3 - 9 } $\begin{array}{l}\text { Constituent } \\
\text { mole ratio }\end{array}$ & $\begin{array}{l}\text { Basaltic } \\
\text { glass }\end{array}$ & 1 & 2 & 3 & 4 & 5 & 6 & 7 \\
\hline K:Na & 0.29 & 0.17 & 0.07 & 0.16 & 0.10 & 0.12 & 0.10 & 0.05 \\
Ca: $N a$ & 1.69 & 1.12 & 1.24 & 0.63 & 0.35 & 0.05 & 0.04 & 0.02 \\
Ca: $\mathrm{Mg}$ & 1.46 & 1.32 & 1.48 & 1.33 & 1.21 & 1.60 & 1.82 & 3.23 \\
\hline
\end{tabular}

Data from the Grande Ronde unit are emphasized because they are the best set of information to use to examine natural water-rock interactions and the attendant hydrochemical evolution. This is because the Grande Ronde unit is the deepest and most extensive unit in the aquifer system; it is confined or overlain by younger units over a large part of its area (about 63 percent) and is generally the least affected by land-use practices. Generally only the data with dissolved nitrogen $(\mathrm{N})$ species-nitrate $\left(\mathrm{NO}_{3}\right)+$ nitrite $\left(\mathrm{NO}_{2}\right)$-concentrations less than $1.0 \mathrm{mg} / \mathrm{L}$ are discussed in order to eliminate land-use effects. This sample stratification does not appear to have biased data interpretation, beyond the elimination of anthropogenic effects; these effects were discussed by Steinkampf (1989).

The Grande Ronde unit data described above were used to calculate speciation data and the state of thermodynamic equilibrium of selected solid phases. Selected speciation and stability data for sites with multiple analyses were then averaged; this data set is the average of analytical values for each Grande Ronde unit site (table 6). This set is used for most graphical analyses. In discussions where logarithmic values are described as averages, the data were first converted to actual concentrations, products, or ratios as appropriate, then the logarithms of means were calculated. Additionally, analytical and field data for the summer (August) 1983 samples from sites 1 , 2 , and 3 (see table 5 ; sites 45,55 , and 59 in table 6) that are along a flow path in the Grande Ronde unit are used in the geochemical analysis of basalt-water mass balance.

Some spatial variations of the ground-water chemistry were determined on a temporal basis. Radiocarbon ages were calculated and used to estimate net rates of accumulation of selected dissolved species. Although uncorrected ages likely are not accurate, this approach was used rather than an attempt to correct the ages for: (1) the contributions of carbon from dissolution of pedogenic carbonates and open-system input of carbon dioxide, (2) the possibility of multistage evolution, and (3) the effects of isotopic fractionation. This is because the data required to correct the ages generally are not available. However, using the method of Ingerson and Pearson (1964), corrections were calculated using available stable-carbon isotopic data for the sites for which radiocarbon data are available, and bicarbonate-carbon dioxide fractionation factors from Friedman and O'Neil (1977, figure 27, curve B). Corrections ranged from 3,180 to 4,660 years, with a mean of 3,830 years, over a range of average uncorrected ages from 7,150 to 27,950 years. Radiocarbon contents, rather than uncorrected ages, were used in most interpretive efforts. 


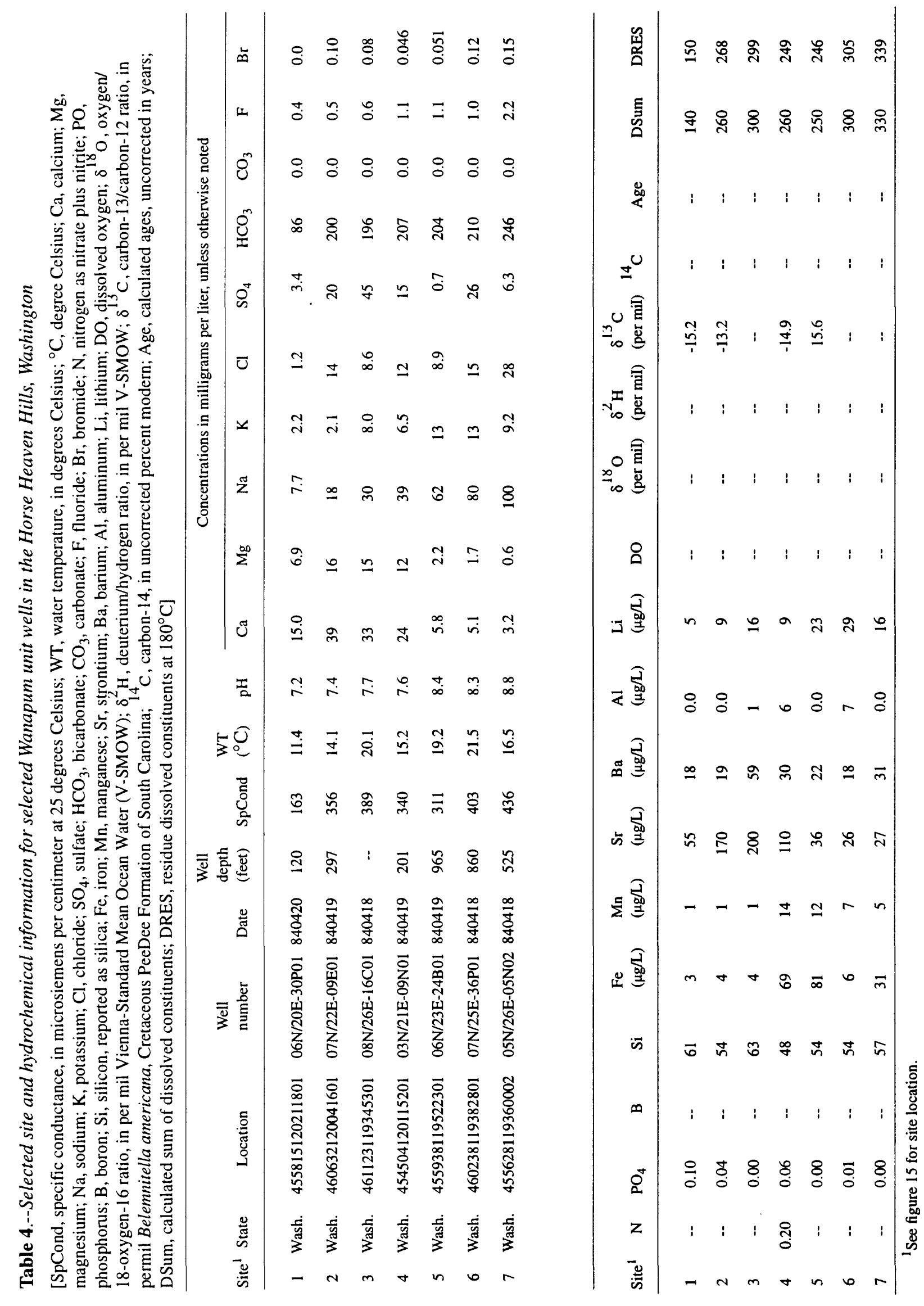



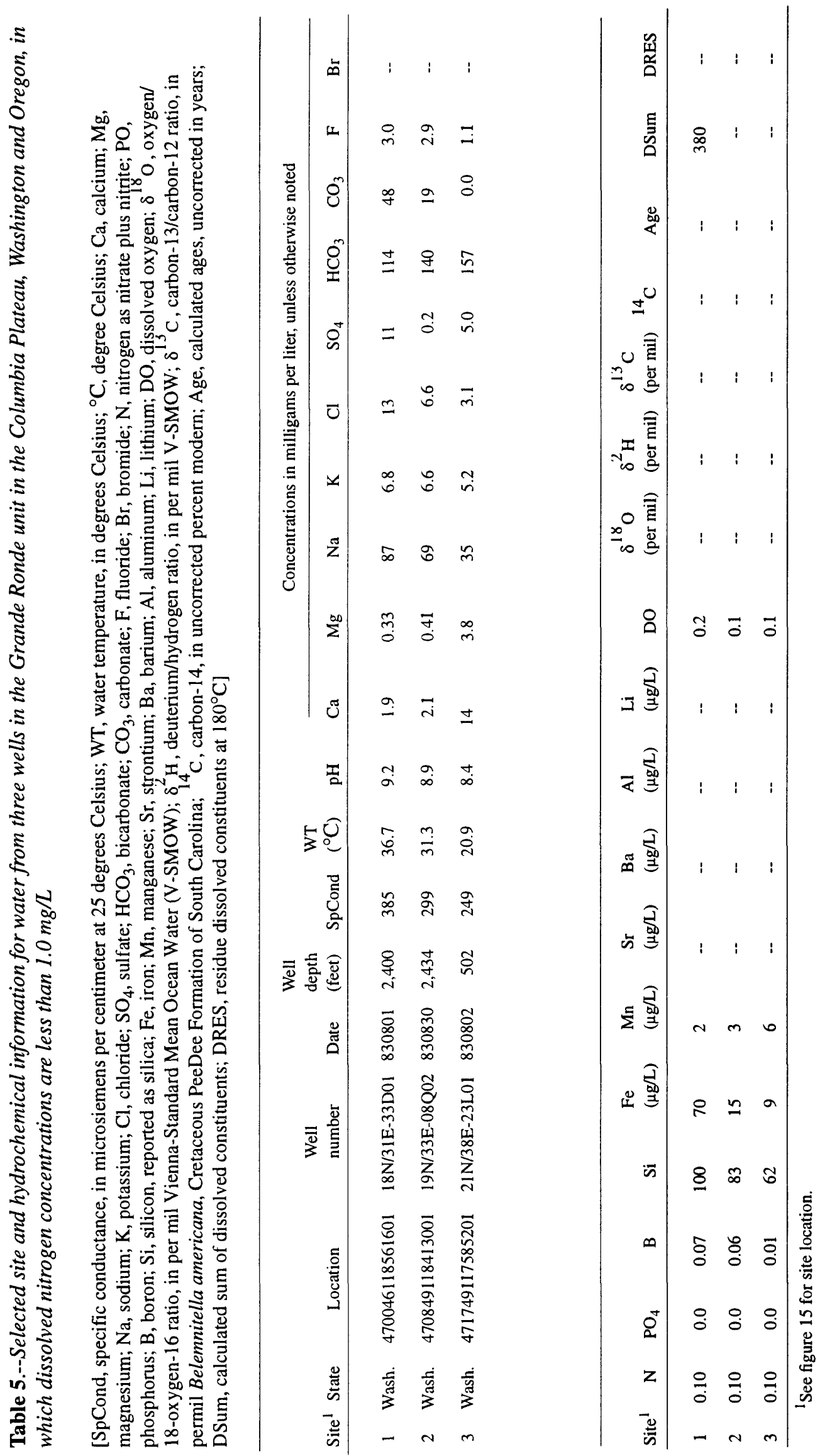


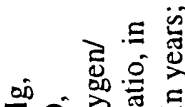

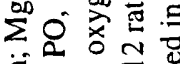
हैं

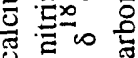

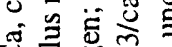
뭉

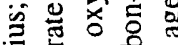

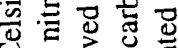

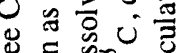

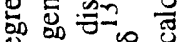
论急完密

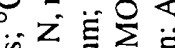

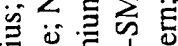

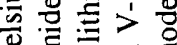
U 过

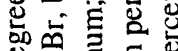
ष

$\Xi$ 㛡

5 당

至元莙

एँ

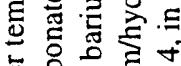

造造过代

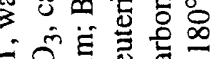

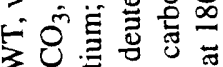

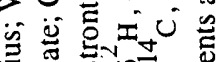
解事

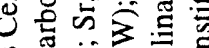

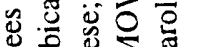

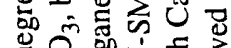
论先之至

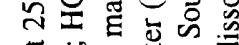

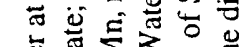

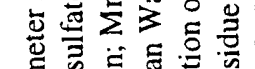
舫递

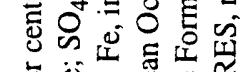

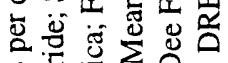

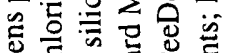

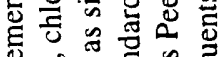

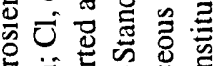

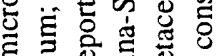
氶氙芯导 s 휴웡

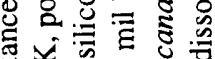

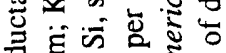

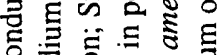
엉

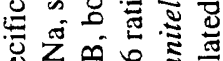

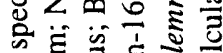
ปี

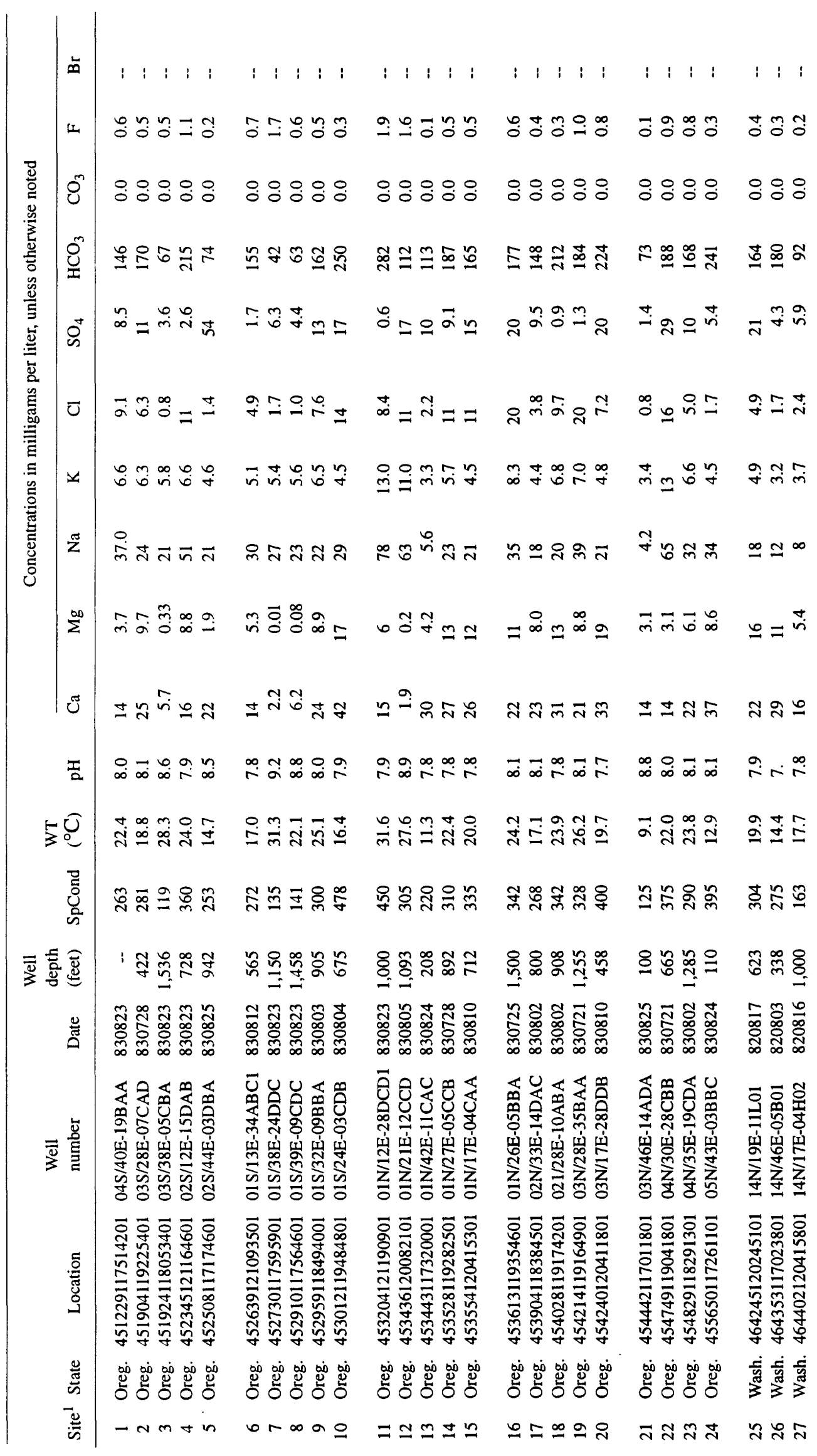




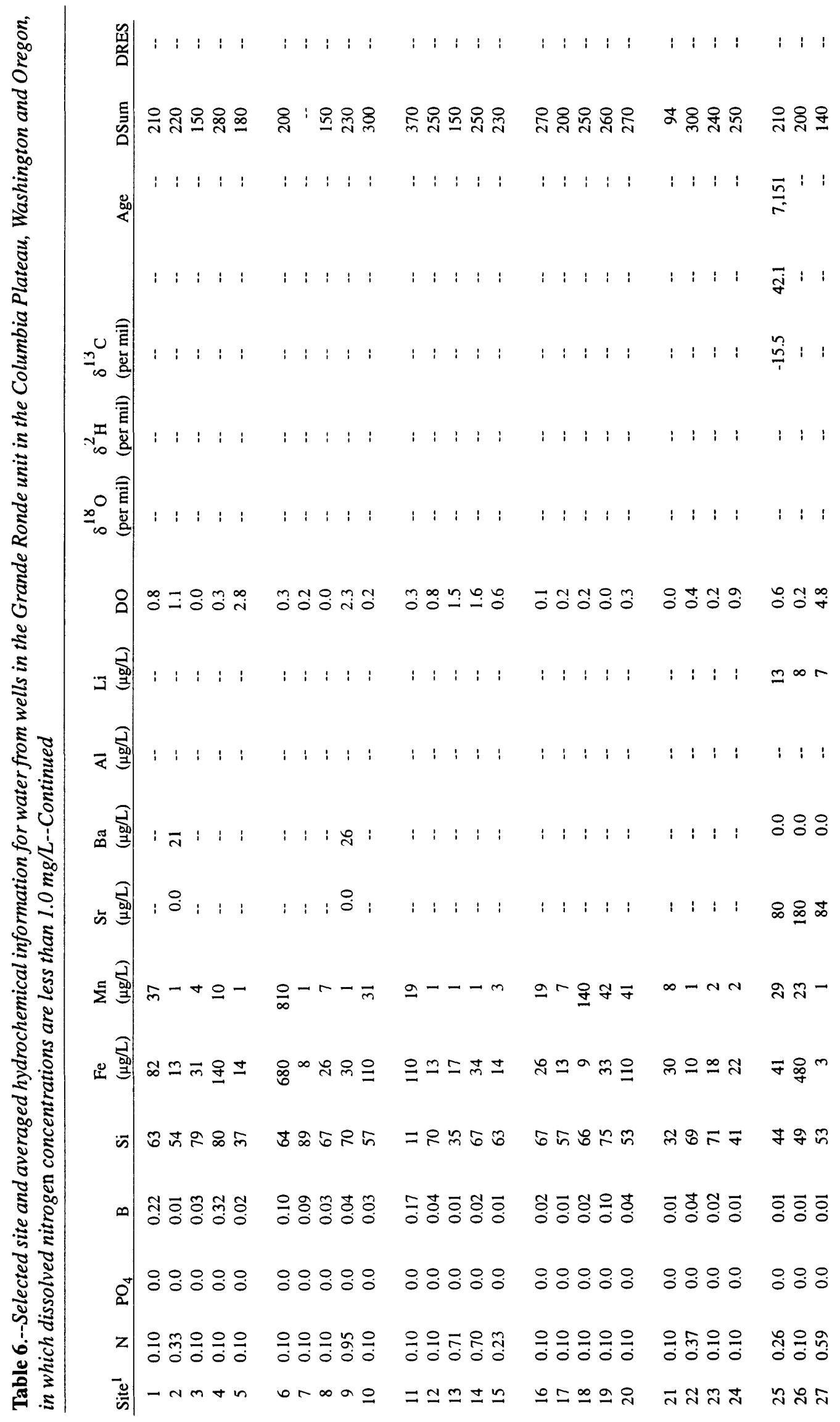




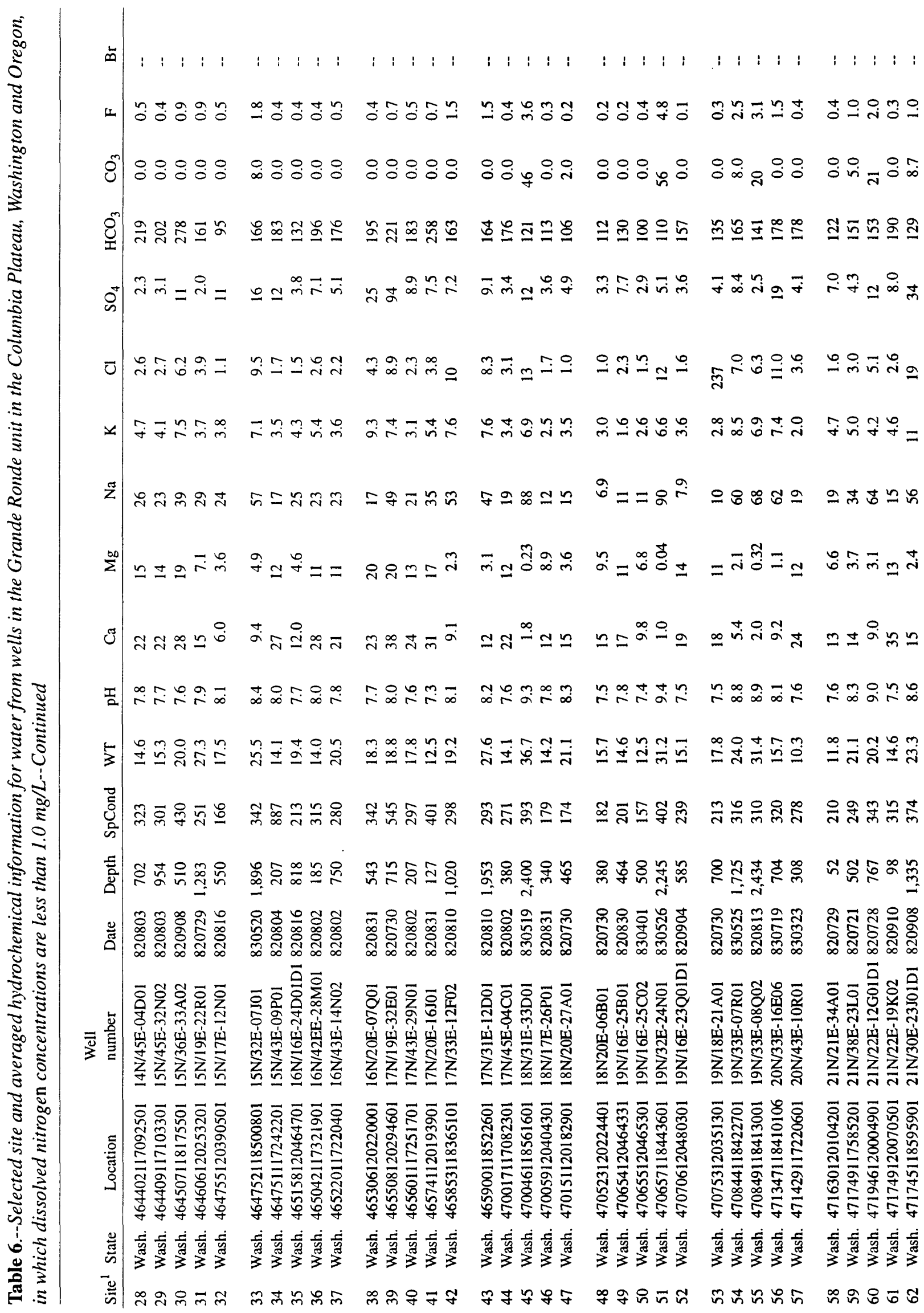




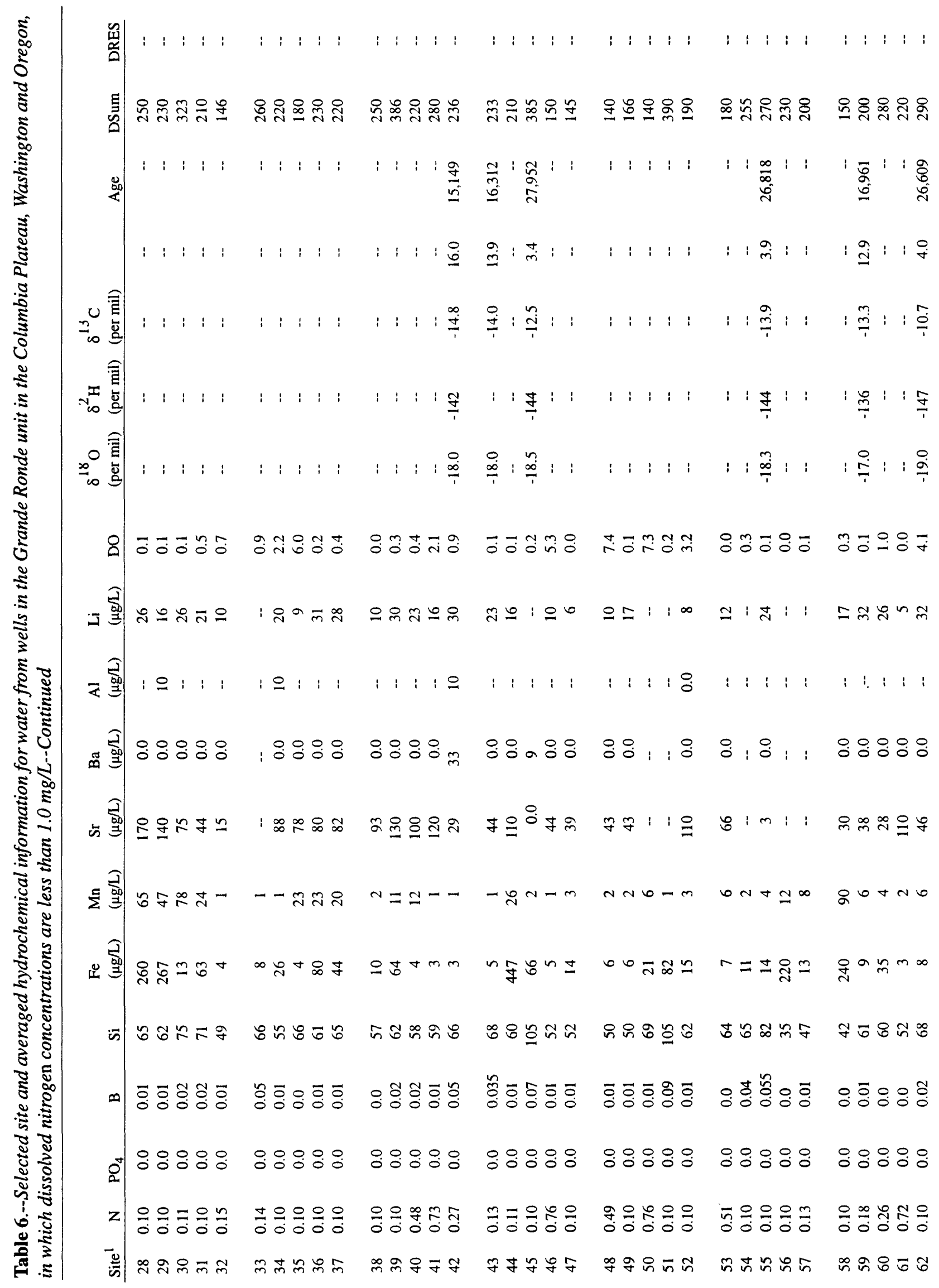




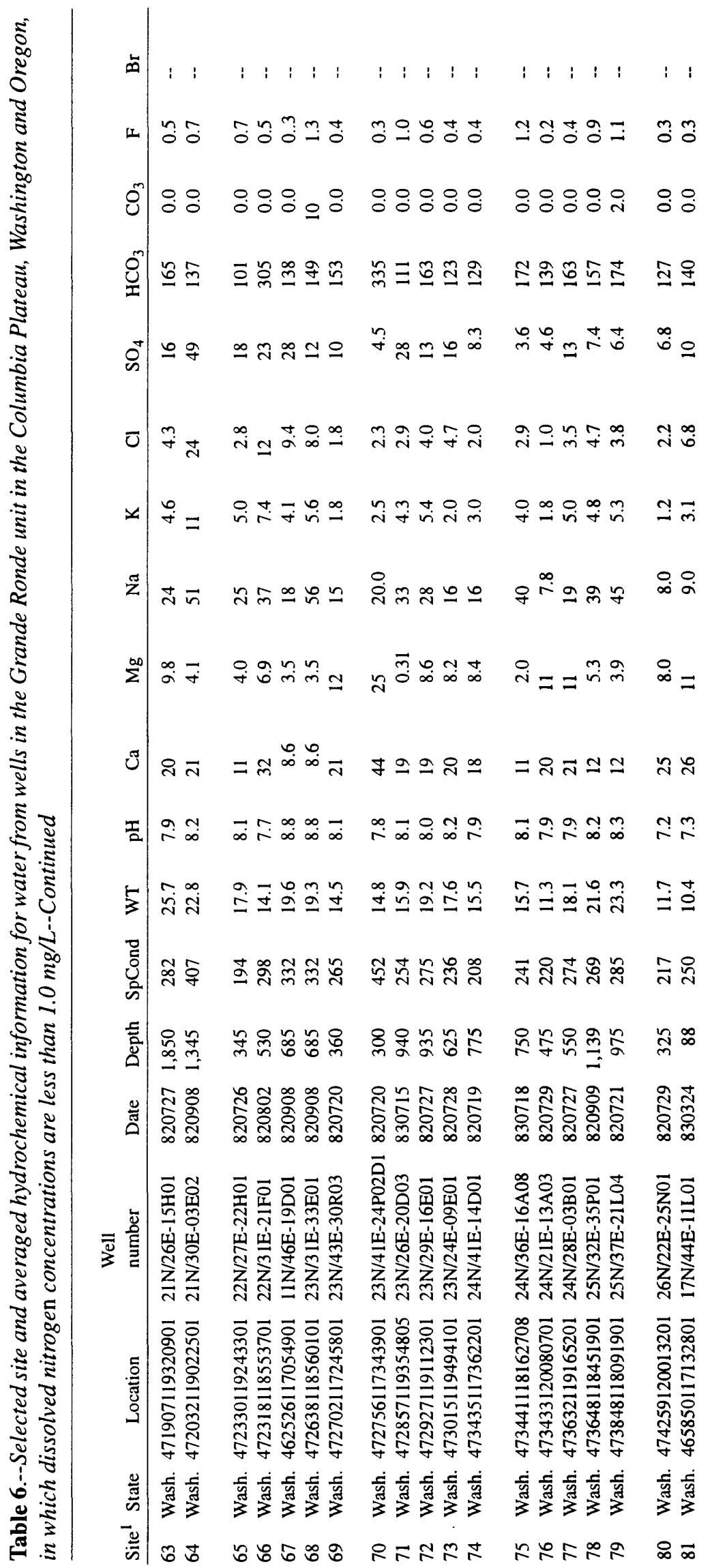




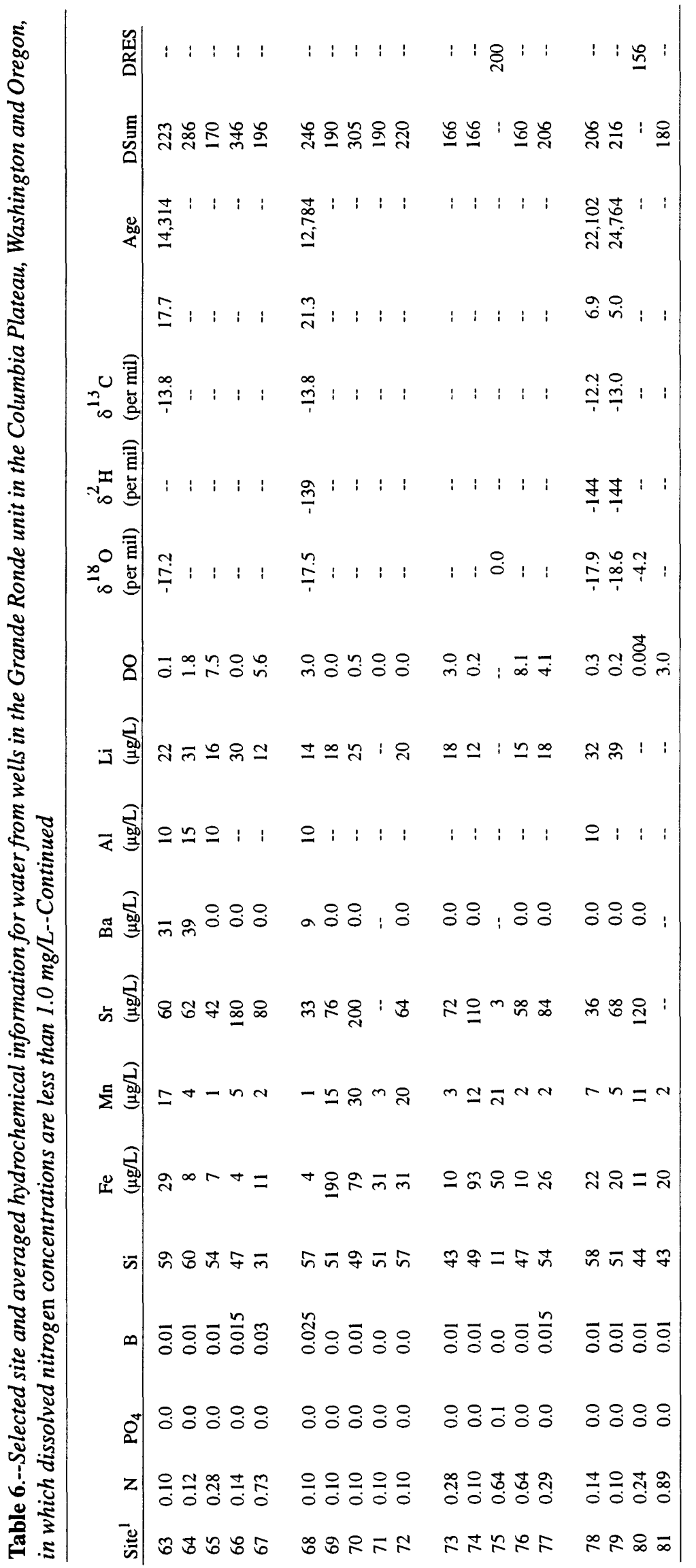




\section{GEOCHEMISTRY}

In order to understand the geochemistry of the aquifer system, several factors need to be analyzed. These are the mineralogy of the basalt; the spatial variations in chemical constituents and their concentration factors that affect the hydrochemical processes; the chemical evolution of the flowing ground waters, including the basalt-water reactions; the estimated controls of secondary minerals on observed chemical concentrations; and the basalt-water mass balance. Therefore, this section, excluding the mineralogy which was described previously, discusses each of these items.

The generalized chemical characteristics, including the major chemical water types and constituents observed in the system are described first. The next section describes the processes and reactions that can account for the chemical concentrations and provides an overview of the major processes that affect the chemistry. Next, the evolution of the chemistry is discussed using the general reaction scenario of Hearn and others (1985). In this section, the role of the major chemical constituents involved in reactions is described and examples are presented. Excluding external sources, reactions account for the sources and sinks of constituents and their spatial variability. Generally, $\mathrm{Na}$ is used as an indication of reaction progress. However, other species, such as $\mathrm{Ca}$ and $\mathrm{Cl}$, also are used because their concentration changes with time and they provide information on geochemical controls. The control that secondary minerals provide to reactions and the subsequent accumulation of dissolved materials is discussed in the next section. These controls are described on the basis of secondary minerals observed in drill cores. Last, the processes and reaction scenario are synthesized using a basalt-water mass balance. The reactions used in the mass-balance indicate the correctness of the proposed model for chemical evolution and establish the importance of the various geochemical controls.

\section{Generalized Chemical Characteristics}

The ground-water chemistry in the basalt units in several areas of the Columbia Plateau has been described most recently at various scales and in varying levels of detail by Steinkampf (1989), Lambert and others (1989), Hoover and Murphy (1989), Bortleson and Cox (1985), Hearn and others (1985), Steinkampf and others (1985), and Ebbert (1984). The reader is referred to these reports, particularly the first, for a more detailed description than is contained herein.
Ground waters in the basalt units of the aquifer system are generally of good quality and are suitable for most uses. The most prevalent water types in each of the three units are calcium magnesium bicarbonate $\left(\mathrm{CaMgHCO}_{3}\right)$ and sodium bicarbonate $\left(\mathrm{NaHCO}_{3}\right)$ waters (Bortleson and Cox, 1985). The former are found in the upgradient parts of the aquifer system and the latter are more common in central and downgradient parts of the system. Other water types appear to derive primarily from either anthropogenic inputs in areas with relatively thin or highly permeable overburden materials, or from upward flow of ground water from deeper parts of the flow system in the central part of the plateau. The dominant ground-water cations and anions are calcium $(\mathrm{Ca})$, magnesium $(\mathrm{Mg})$, sodium $(\mathrm{Na})$, carbonate $\left(\mathrm{CO}_{3}\right)$, silicon $\left(\mathrm{Si}\right.$, reported as $\left.\mathrm{SiO}_{4}\right)$, sulfate $\left(\mathrm{SO}_{4}\right)$, and chloride (Cl) (table 2). Dissolved-solids concentrations generally are less than $500 \mathrm{mg} / \mathrm{L}$. Ground waters have locally large dissolved $\mathrm{N}$ concentrations; these appear to be related to land use because large concentrations are inversely related to well depth and overburden thickness (Steinkampf, 1989).

Although $\mathrm{Ca}$ and $\mathrm{Mg}$ concentrations tend to decrease both with increasing depth in the system and from outcrop areas toward both the Columbia River and the center of the plateau, concentrations of most other major dissolved species increase with residence time in all of the basalt units. Lines of equal concentration values for the major anionic and monovalent cationic constituents roughly parallel potentiometric contours for each of the units (Steinkampf, 1989). This tendency is less pronounced for the Saddle Mountains unit because it has the smallest lateral extent and also is discontinuous; it overlies a large part of the regional discharge area; and it underlies most of the surface-water-irrigated croplands. In the Grande Ronde and Wanapum units, variations from these trends generally occur in agricultural areas where the overburden is thin or absent. Examples are the region adjacent to and north of Ellensburg, Wash., where the Grande Ronde unit is at or near land surface and in northern and central Lincoln County, Wash., where large dissolved $\mathrm{N}$ concentrations in the plateau are most numerous in the Wanapum unit (fig. 3). Variations also appear to be associated with agricultural areas where surface water is used for irrigation in the Saddle Mountains and Wanapum units in the southern half of Grant County, Wash. (Steinkampf, 1989). 


\section{Hydrochemical Processes}

Ground-water recharge on the plateau consists of rain, snowmelt, and stream, lake, and irrigation waters. Hydrogen and oxygen stable isotope data (fig. 8) show that the recharging water is initially modified by evaporation, as indicated by the apparent departure from the trend of data for eight North American stations (Gat, 1980, p. 32). As these waters percolate through the unsaturated zone to the water table, their chemical compositions are altered. The changes are determined by the chemistry of the recharging water and subsequent reactions that occur as water moves through the soil (root) and unsaturated zones. The dominant natural reaction in the unsaturated zone probably is the dissolution of carbon dioxide $\left(\mathrm{CO}_{2}\right)$, which even in arid areas can be present in the soil in concentrations more than an order of magnitude larger than atmospheric. This dissolution tends to lower the $\mathrm{pH}$ of the percolating water. Concurrently, the water can react with soil mineral phases, increasing the solute load and raising the soil-water $\mathrm{pH}$. The importance of this general reaction depends on the types and amounts of soluble and (or) reactive materials present in the unsaturated zone.

Natural changes in water chemistry in the saturated zone result from low-temperature water-rock reactions and (or) mixing with another water with a different composition and the subsequent reactions. The types and extents of reactions depend on the composition of the recharged water, the chemical compositions and solubilities of the solid phases present, the rate of ground-water flow, differences in chemistries and physical properties of the mixing waters, and the extent to which the ground water is isolated from the atmosphere and the gas phase in the unsaturated zone.

Hydrochemically, basaltic glass is the most important solid phase present in the basalts. Because of its disordered structure and large surface area, it reacts readily with both recharge and ground waters (Jones, 1966), primarily by hydrolysis and reaction with carbonic acid (from soil-zone $\mathrm{CO}_{2}$ ). Glass solubility increases significantly with increasing water temperature, and there have been several experimental studies of basalts in lowionic-strength waters at elevated temperatures (Ellis and Mahon, 1964, 1967; Hawkins and Roy, 1963; Jenkins and others, 1984; Moore and others, 1983). These studies have shown that $\mathrm{Si}$-rich and $\mathrm{Mg}$-poor glasses are less soluble than those with lower Si content, and that the initial composition of the glass is more important in determining secondary minerals in closed systems than in open systems. White and Clasen (1979), White and others (1980), and White (1983) examined the interaction of relatively low-ionic-strength waters with silicon-rich rhyolitic glasses both in the laboratory and in field studies in southern Nevada. They concluded that dissolution of glassy material follows a parabolic rate law and is the most significant process contributing dissolved material to ground waters in rhyolitic, ash-fall, and ash-flow tuffs.

Few investigations have addressed basaltic glass dissolution near room temperature. Furnes (1975) established laboratory rates of palagonitization of basaltic glass at a pH of 6.0. Jakobsson (1978) examined palagonitization of Surtsey tephra, noting both the direct relation between accumulation rate and temperature and the sequence of subsequent secondary mineralization. Gislason and Eugster (1987a) experimentally concluded that dissolutions of basaltic glass and crystalline basalt in water follow linear rate laws. They further found that glass dissolution is nearly stoichiometric at $25^{\circ} \mathrm{C}$, and that the types of secondary mineral phases resulting from glass-water interaction depend on the degree of isolation from the atmosphere. Their finding of a linear rate law does not necessarily contradict the findings of White and others (1980) and White (1983), whose investigations used buffered solutions with pH's ranging from 2 to 7 , a range over which the dissolution rate is highly dependent on $\mathrm{pH}$.

Although the discovery of submarine hydrothermal systems in the last decade has prompted a large amount of field and experimental work in the seawater-basalt system, natural interactions between basalts and meteoric or ground waters have received little attention. Hay and Jones (1972) delineated weathering reactions in Hawaiian basaltic tephra, and Chesworth and others (1981) studied a French basalt weathering profile. Ellis and Mahon (1964, 1967), Arnason (1977), Armannsson and other (1982), and Arnorsson and others (1983a,b) examined basalt-ground water relations in geothermal systems. Wood and Low $(1986,1988)$ discussed controls on ground-water chemistry in the eastern Snake River Plain basalt aquifer system in Idaho. Although their mass-transfer calculations included described mineral phases, they did not include basaltic glass, which they recognized as a possible solute source. Gislason and Eugster (1987b) addressed a wide thermal range of waters in their investigation and described the evolutions of distinct water chemistries in Quaternary basalts in northeastern Iceland. Hearn and others (1985) presented a model for the evolution of ground-water chemistry in the Columbia River Basalt Group in which basaltic glass is the dominant source of dissolved material. 


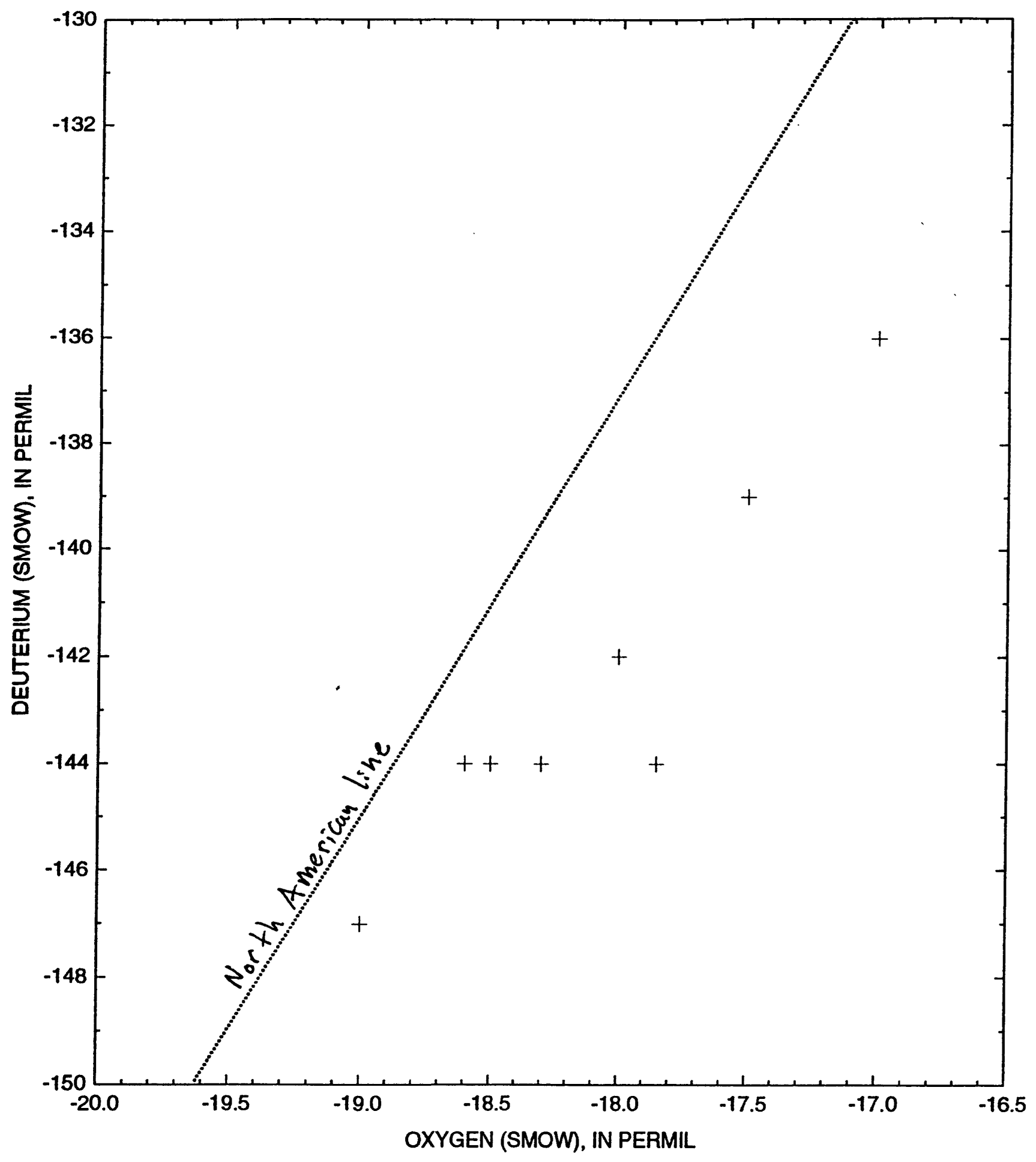

Figure 8.--Average oxygen-18 and deuterium ratios for samples from wells in the Grande Ronde unit in which dissolved nitrogen concentrations are less than 1.0 milligram per liter. North American precipitation line from Gat (1980). Data from table 6. 


\section{Hydrochemical Evolution}

The hydrogeologic units in the plateau are recharged primarily by meteoric waters, both snowmelt and rain, either directly in outcrop areas or through streams and lakes that act as "line sources". The chemistry of these dilute waters changes rapidly with contact with the basalt. They quickly acquire additional dissolved materials, primarily by dissolution of glassy and cryptocrystalline phases. The general reaction scenario described by Hearn and others (1985) begins with this dissolution.

Dissolution occurs by means of $\mathrm{CO}_{2}$-charged waters and hydrolysis. Of the glass components, aluminum ( $\mathrm{Al})$ and iron (Fe) are among the least soluble in the groundwater chemical environment. Aluminum rapidly precipitates as amorphous aluminosilicate, or perhaps as an oxyhydroxide. Iron is oxidized if dissolved oxygen (DO) is present and precipitates as an oxyhydroxide. These precipitations also probably remove most trace or heavy metals that also are derived from the glass dissolution. With time, the amorphous aluminosilicate tends to become more structurally ordered and attains a smectitic composition and structure. A major result of the hydrolysis reaction is the increase of ground-water $\mathrm{pH}$ by the net production of hydrogen $(\mathrm{H})$ and hydroxyl $(\mathrm{OH})$ ions. As ground-water $\mathrm{pH}$ increases and the concentrations of other glass components also increase, the solubility limits of carbonate minerals are exceeded. Because $\mathrm{Ca}$ is significantly abundant in basaltic glass and $\mathrm{HCO}_{3}$ is present from the dissolution of soil $\mathrm{CO}_{2}$, calcite $\left(\mathrm{CaCO}_{3}\right)$ precipitates from solution. This step also can remove other divalent metals, including $\mathrm{Fe}$, from solution. Although the above reactions tend to restrict increases in $\mathrm{Al}, \mathrm{Fe}, \mathrm{Si}$, and $\mathrm{Ca}$ concentration, other glass components, including $\mathrm{Na}$, $\mathrm{K}$, and $\mathrm{Si}$, continue to increase in concentration with additional glass dissolution. Silicon concentrations are limited somewhat by the precipitation of an amorphous Si phase that becomes more ordered over geologic time to something like $\alpha$-cristobalite. When $\mathrm{Na}, \mathrm{K}$, and $\mathrm{Si}$ concentrations are sufficiently large and when $\mathrm{pH}$ and ionic strength conditions are sufficient, zeolite phases can form. These precipitations further control solute concentrations.

As the above processes occur, concentrations generally continue to increase downgradient in the flow system, as exemplified by the areal and vertical distribution of $\mathrm{Na}$ concentrations in the Grande Ronde unit (fig. 9). Concentrations in outcrop areas generally are less than $25 \mathrm{mg} / \mathrm{L}$, and the largest values occur almost exclusively in downgradient locations. Concentrations generally also increase with depth in the system. Sodium concentrations appear to increase consistently, relative to the total solute concentration, at an overall rate of about $1 \mathrm{mg} / \mathrm{L} \mathrm{Na}$ per $5 \mathrm{mg} / \mathrm{L}$ of dissolved solids (fig. 10). This is far greater than the relative abundance of $\mathrm{Na}$ in basaltic glass (table 1 ) and indicates both that stoichiometric dissolution of glass does not satisfactorily describe the total solute increases and that $\mathrm{Na}$ is preferentially conserved in solution. The consistent increases suggest that $\mathrm{Na}$ can be used as an indicator of the extent to which ground-water chemistry in the study area has evolved. Sodium concentrations also are less likely to be influenced by the use of agricultural chemicals on the plateau, because the addition of $\mathrm{Na}$ to basalt-derived soils reduces their tillability and thus, agricultural chemicals containing $\mathrm{Na}$ generally are not used on the plateau.

The relation between $\mathrm{Na}$ and uncorrected radiocarbon age (fig. 11a) suggests that, disregarding the three outlying points discussed later, $\mathrm{Na}$ concentrations increase, at three different rates. For the concentrations between 0 and about $25 \mathrm{mg} / \mathrm{L}$, the rate of increase is about $1.7 \mathrm{mg} / \mathrm{L}$ per thousand years $(\mathrm{mg} / \mathrm{L} / \mathrm{ka})$. This rate is probably larger than the actual value, because the starting concentration of $0 \mathrm{mg} / \mathrm{L}$ used to calculate the rate is smaller than the concentration in the recharging water. For $\mathrm{Na}$ concentrations between about 25 to $50 \mathrm{mg} / \mathrm{L}$, the rate is about $2 \mathrm{mg} / \mathrm{L} / \mathrm{ka}$; for concentrations more than $50 \mathrm{mg} / \mathrm{L}$, the rate is about $23 \mathrm{mg} / \mathrm{L} / \mathrm{ka}$. Similar to the rate of increase of $\mathrm{Na}$ with dissolved solids, the last rate strongly suggests that increases in $\mathrm{Na}$ concentrations, although a fairly good indicator of evolutionary extent, are not linked solely to the stoichiometric dissolution of glass. Note that the three oldest waters shown on figure 11a were used to estimate the last rate and two of these wells were the deepest wells sampled during the study. Additionally, all three are located east of and adjacent to the East Low Irrigation Canal, the eastern limit of the CBIP (see fig. 1). This is an area of large ground-water withdrawals, and three high-production wells probably induce an upward flux of older water from deeper in the system.

Calcium data for the Grande Ronde unit indicate a rate of overall change of about $-1.0 \mathrm{mg} / \mathrm{L} / \mathrm{ka}$ (fig. $11 \mathrm{~b}$ ). This rate, when compared with the above estimates of $\mathrm{Na}$ rates, is only about 4 percent of the rate that would result if $\mathrm{Na}-\mathrm{Ca}$ exchange were responsible for the largest rate of $\mathrm{Na}$ concentration increase, and about 60 percent of the rate for the increase to $25 \mathrm{mg} / \mathrm{L} \mathrm{Na}$. This suggests that exchange probably is an important process only in the early stage of hydrochemical evolution. 


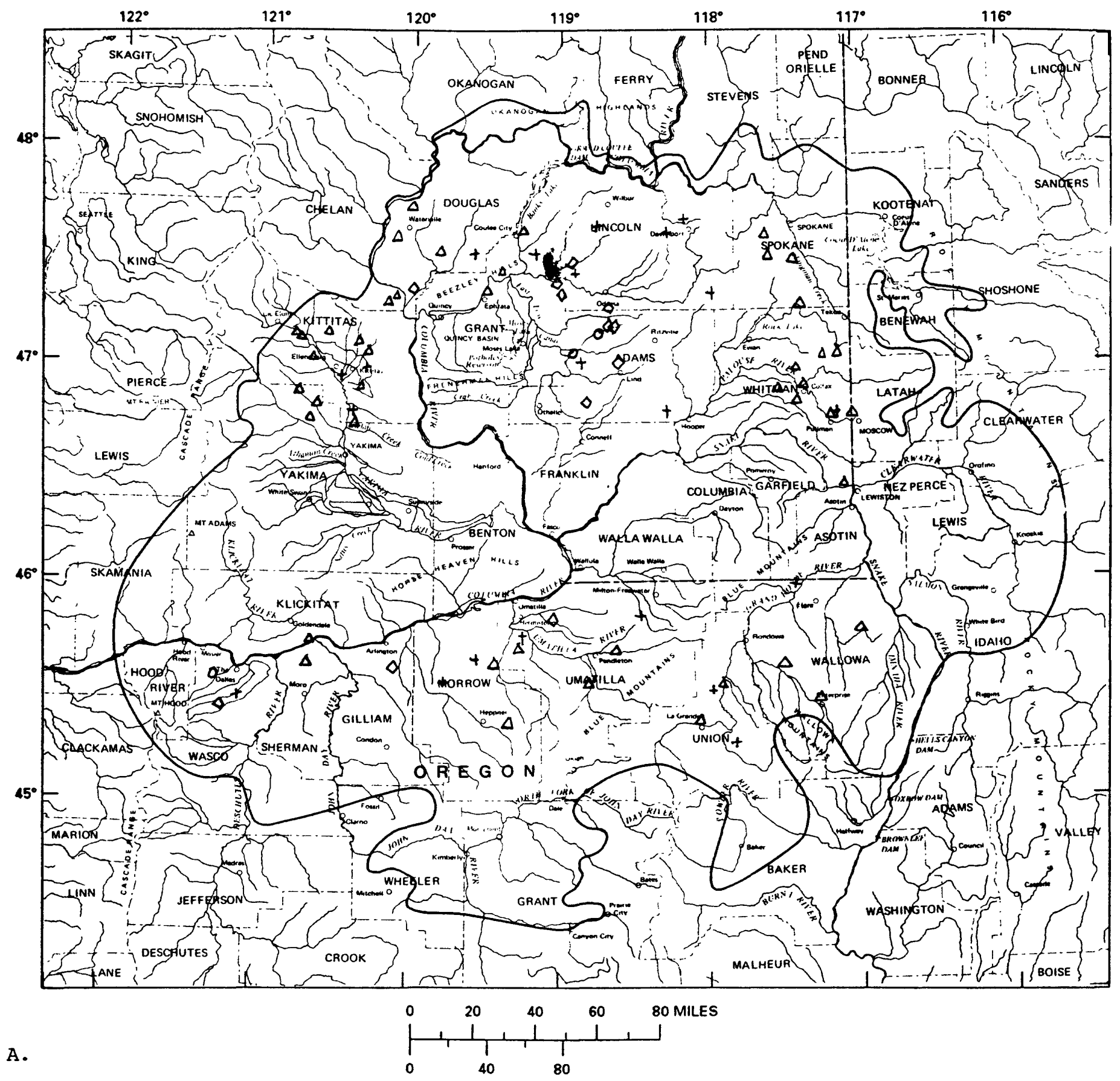

EXPLANATION

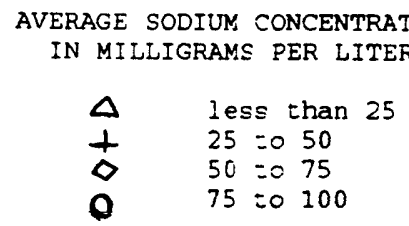

Figure 9.--(A) Areal distribution of averaged sodium concentrations in the Grande Ronde unit (data from table 6), and (B) Relation between averaged sodium concentrations and well depth for the Grande Ronde unit. Data from table 6. 


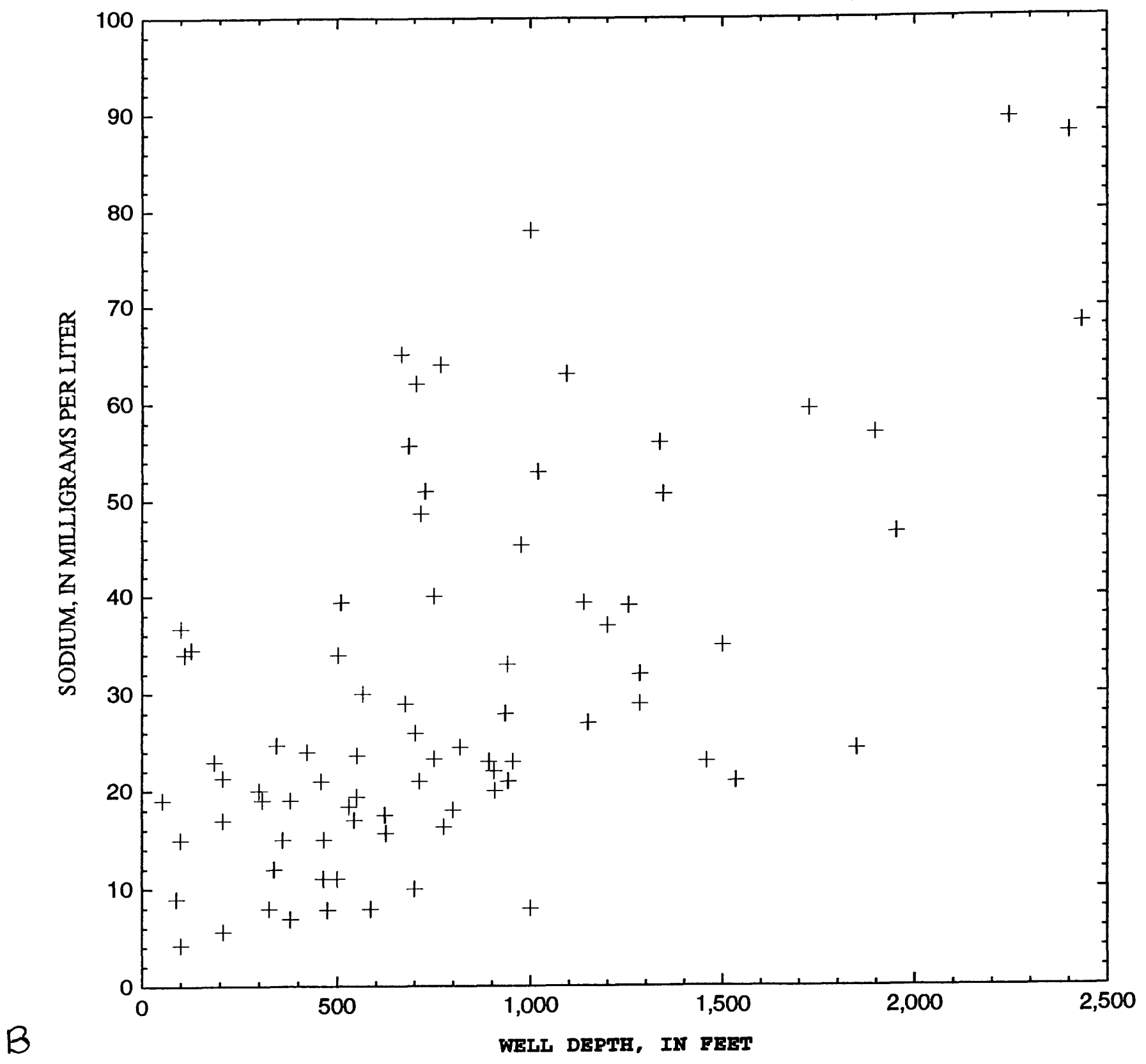

Figure 9.--Continued. 


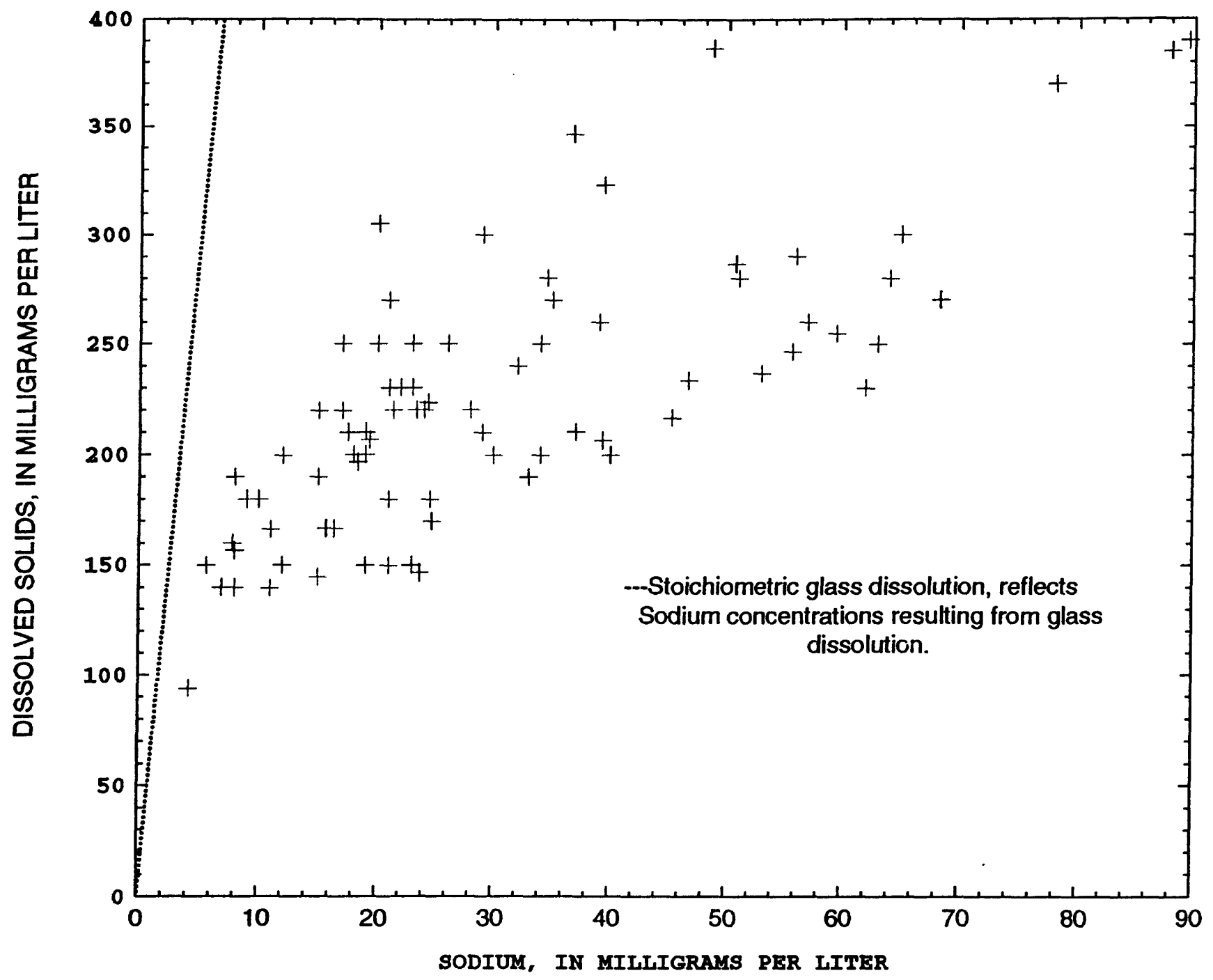

Figure 10.--Relation between averaged dissolved solids and sodium concentration for the Grande Ronde unit. Data from table 6. 

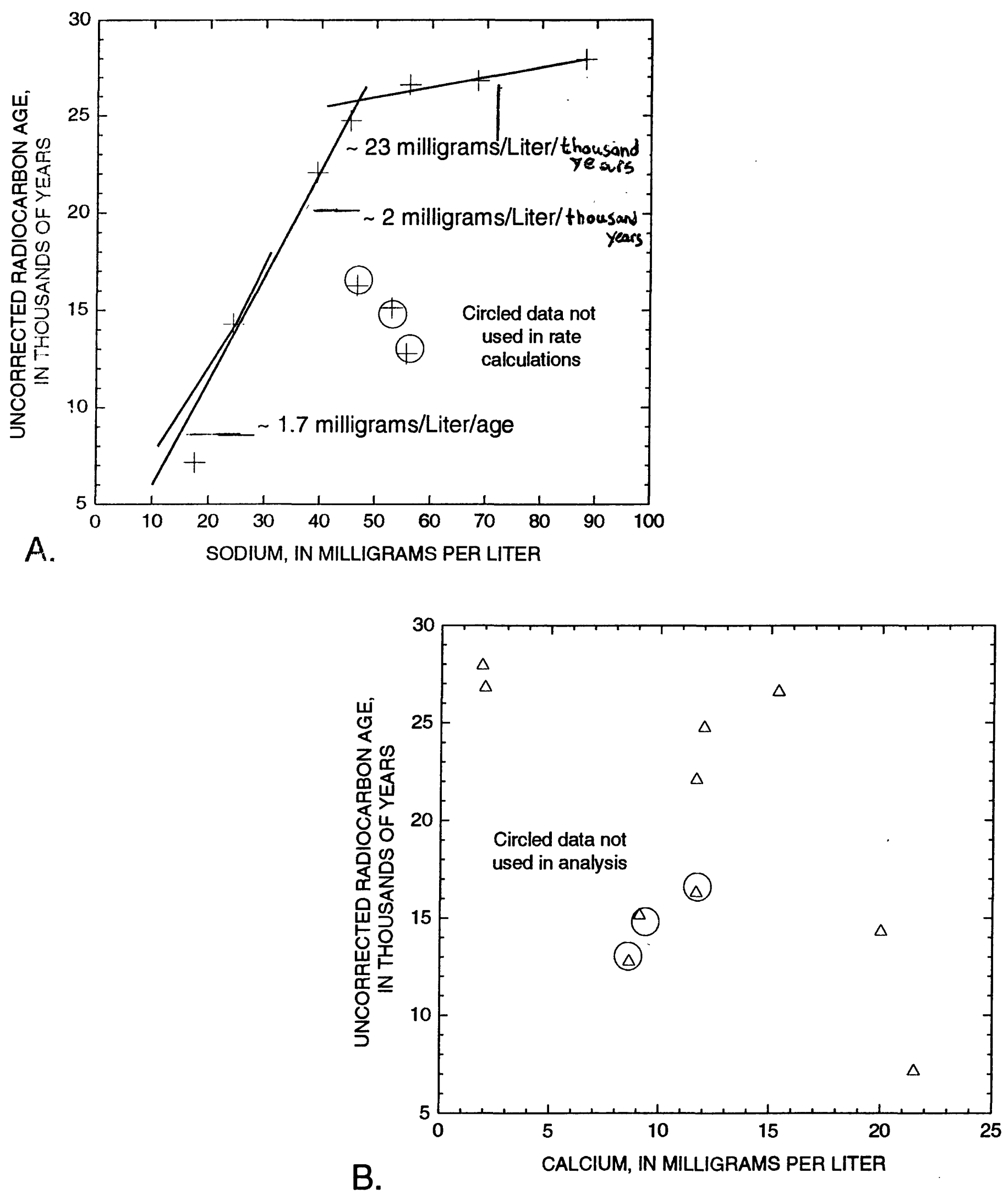

Figure 11.--Relation between averaged uncorrected radiocarbon age and (A) sodium concentration (line segments show estimates of the increase in rates of sodium concentration with time step; data from table 6 and (B) calcium concentration (data from table 6) for the Grande Ronde unit. 
The analyses for the three sites on figure 11 do not follow the general trends, possibly because their radiocarbon age may reflect contamination with atmospheric carbon $(C)$, resulting in underestimation of age. The sites have much lower $\mathrm{Ca}$ and higher $\mathrm{Na}, \mathrm{Cl}$, and $\mathrm{K}$ concentrations than waters of similar ages, possibly indicating additions of deeper, more evolved waters. Resolution of these uncertainties was not possible with available data.

Figure 12 shows relative concentrations of selected cations in waters in the Horse Heaven Hills. Younger waters, as evinced by larger radiocarbon concentrations, have much larger divalent cation concentrations than older waters, and there is a distinct progression to more sodic waters with decreasing percentages of modern carbon (increasing apparent age). The relative decreases in divalent cation concentrations are not uniform, however, as shown by the generally increasing $\mathrm{Ca}: \mathrm{Mg}$ ratios (table 3 ). $\mathrm{HCO}_{3}$ is the dominant anion in these waters (fig. 13a), and it varies by less than 15 percent from upgradient to downgradient location, whereas the relative cation concentrations have large variations. The same relations are evident in the Grande Ronde unit data (fig. 13b).

The relation between $\mathrm{Ca}$ and $\mathrm{Na}$ for the Grande Ronde unit (fig. 14a) shows that $\mathrm{Ca}$ concentrations generally decrease with increasing $\mathrm{Na}$ concentrations. The Horse Heaven data (fig. 14b) present a more distinct picture of downgradient variation that agrees with the Grande Ronde unit data, suggesting that the changes with time are systematic responses to different processes. The concentration increase between the first two Horse Heaven Hills data points (sites 1 and 2, fig. 14b) is 1.34 moles of Ca per mole of $\mathrm{Na}$. This ratio is similar to the $\mathrm{Ca}: \mathrm{Na}$ mole ratio for glass of 1.69 (table 3) and supports Gislason and Eugster's (1987a) findings that basaltic glass dissolution is nearly stoichiometric. Although these two sites are the most upgradient and appear to have the least evolved waters, they are not on a single flow line as inferred from the contours shown on figure 15. However, their data are examined to determine if exchange can account for changes in $\mathrm{Ca}$ concentration under the assumption they are on a flow line that ends at site 5. This examination is supported to some extent by the $\mathrm{K}: \mathrm{Na}$ and $\mathrm{Ca}: \mathrm{Na}$ mole ratios at site 1 (table 3), which are 59 and 66 percent of the corresponding glass values, and by the generally continuous decreases in these ratios in downgradient samples. The $\mathrm{Si}$ concentration at site 1 (table 4 ) indicates that a large amount of dissolution has already taken place, and it is reasonable to assume that subsequent reactions have altered the initial contributions of dissolved materials and influenced the ionic ratios. Note that the cation data for site 2 (table 4) also could include an anthropogenic influ- ence (see the ratios in table 3 ). Sites 2 and 5 are nearly on a flow line (fig. 15). The downgradient change in $\mathrm{Ca}$ concentration is $-0.77 \mathrm{mmol} / \mathrm{L}(-31 \mathrm{mg} / \mathrm{L})$, and the attendant $\mathrm{Na}$ change is $1.94 \mathrm{mmol} / \mathrm{L}(44.5 \mathrm{mg} / \mathrm{L})$. This yields a molar change ratio of 0.4 . For $\mathrm{Ca}: \mathrm{Na}$ exchange to account for this $\mathrm{Na}$ variation, the ratio would have to be 0.5 , with a $\mathrm{Ca}$ change of $-0.97 \mathrm{mmol} / \mathrm{L}(-38.8 \mathrm{mg} / \mathrm{L})$, or a Na change of $1.54 \mathrm{mmol} / \mathrm{L}(35.4 \mathrm{mg} / \mathrm{L})$. Therefore, exchange is insufficient to account for the observed change in $\mathrm{Ca}$ concentration.

The K:Na and $\mathrm{Ca}: \mathrm{Na}$ ratios for the Grande Ronde unit range from 0.039 to 0.476 and 0.006 to 3.07 , with means of 0.125 and 0.575 , respectively. Comparisons of the ratios with associated radiocarbon data generally show that the apparently youngest waters are those having the highest ratios (fig. 16). Although both $\mathrm{Na}$ and $\mathrm{K}$ are being added to the system, the slope of the nearly linear relation between $\mathrm{K}: \mathrm{Na}$ and age, and the increasing concentrations of $\mathrm{Na}$ with depth, downgradient in the flow system, and over time (figs. $9 \mathrm{~b}$ and 11 ), further indicates that $\mathrm{K}$ is being removed by some means, such as secondary mineralization, or perhaps ion exchange.

Chloride is essentially a non-reactive element in fresh ground and surface waters. The above suggests that the spatial variations of $\mathrm{Cl}$ concentrations may be a good indicator of the evolution of ground waters and they may provide valuable information on the rates of basalt dissolution, which is the primary source of solutes in the system. Dissolved $\mathrm{Cl}$ in the ground water is initially derived from precipitation. Chloride concentrations in the Grande Ronde unit generally are less than $10 \mathrm{mg} / \mathrm{L}$

(fig. 17); the source for larger concentration values probably is either anthropogenic or is a contribution from older, more evolved waters. Chloride concentrations at sites having radiocarbon data suggest that the rate of $\mathrm{Cl}$ accumulation may be on the order of $0.3 \mathrm{mg} / \mathrm{L} / \mathrm{ka}$ (fig. 18). Subsequent increases in $\mathrm{Cl}$ concentration occur through dissolution of agricultural chemicals and basalt dissolution. To determine potential basalt dissolution rates and accumulation rates of $\mathrm{Cl}$, the initial concentration and potential sources of $\mathrm{Cl}$ need to be known. Concentrations in Columbia River waters used for irrigation range from 0.3 to $1.5 \mathrm{mg} / \mathrm{L}$, and average about $0.6 \mathrm{mg} / \mathrm{L}$. Laird and others (1986) reported analyses of 27 snow samples collected at altitudes ranging from 4,200 to 7,420 feet in the Cascade Range in February and March 1983; the mean Cl concentration was $0.3 \mathrm{mg} / \mathrm{L}$. This mean value is a reasonable estimate of an initial $\mathrm{Cl}$ concentration for rain and snow on the plateau, as indicated by the minimum analytical value of $0.5 \mathrm{mg} / \mathrm{L}$ for the Grande Ronde unit waters (table 2). 


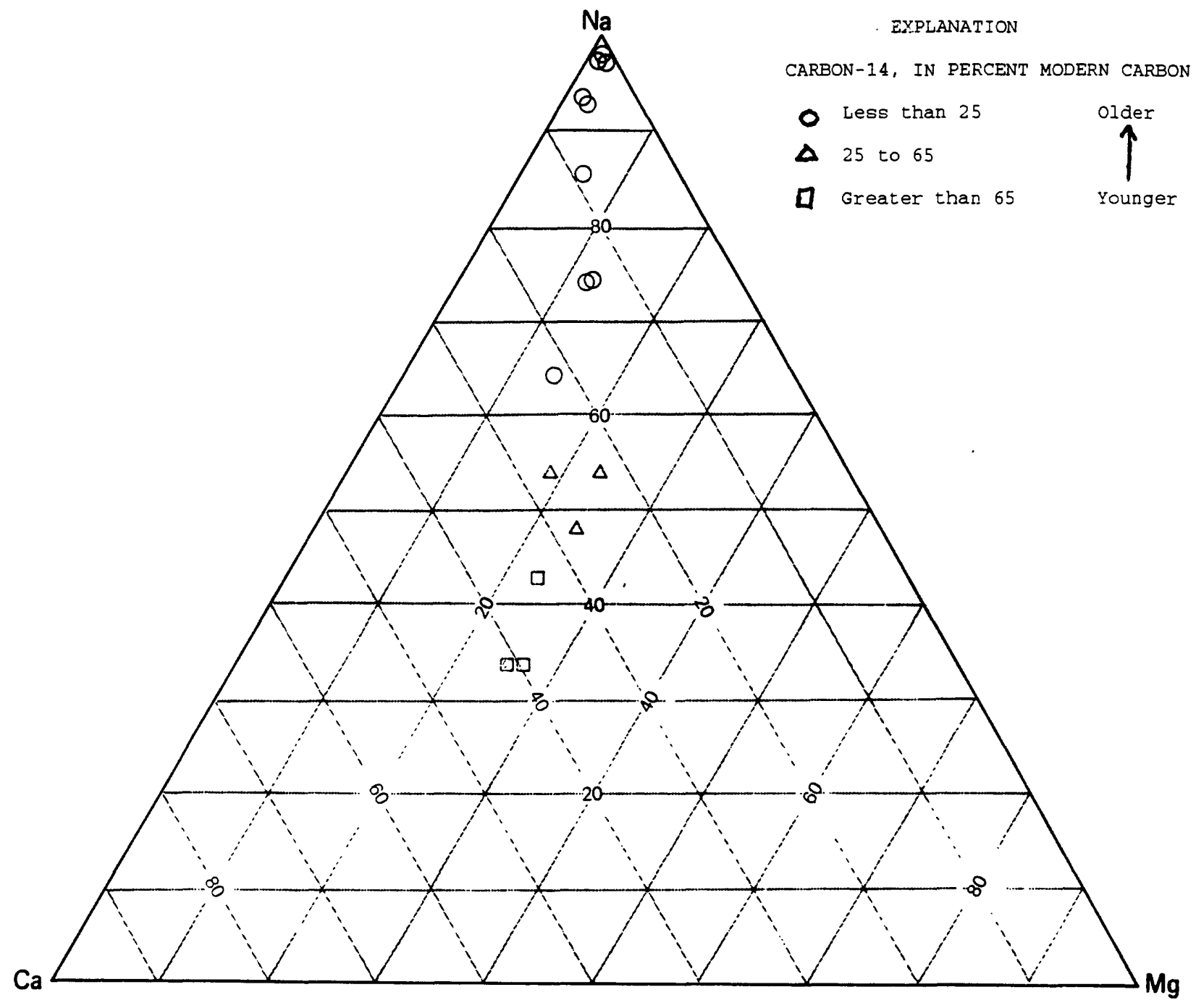

Figure 12.--Relative molar calcium (Ca), magnesium $(\mathrm{Mg})$, and sodium $(\mathrm{Na})$ concentrations for selected sites in the Horse Heaven Hills, grouped by radiocarbon values. After Hearn and others (1985). 


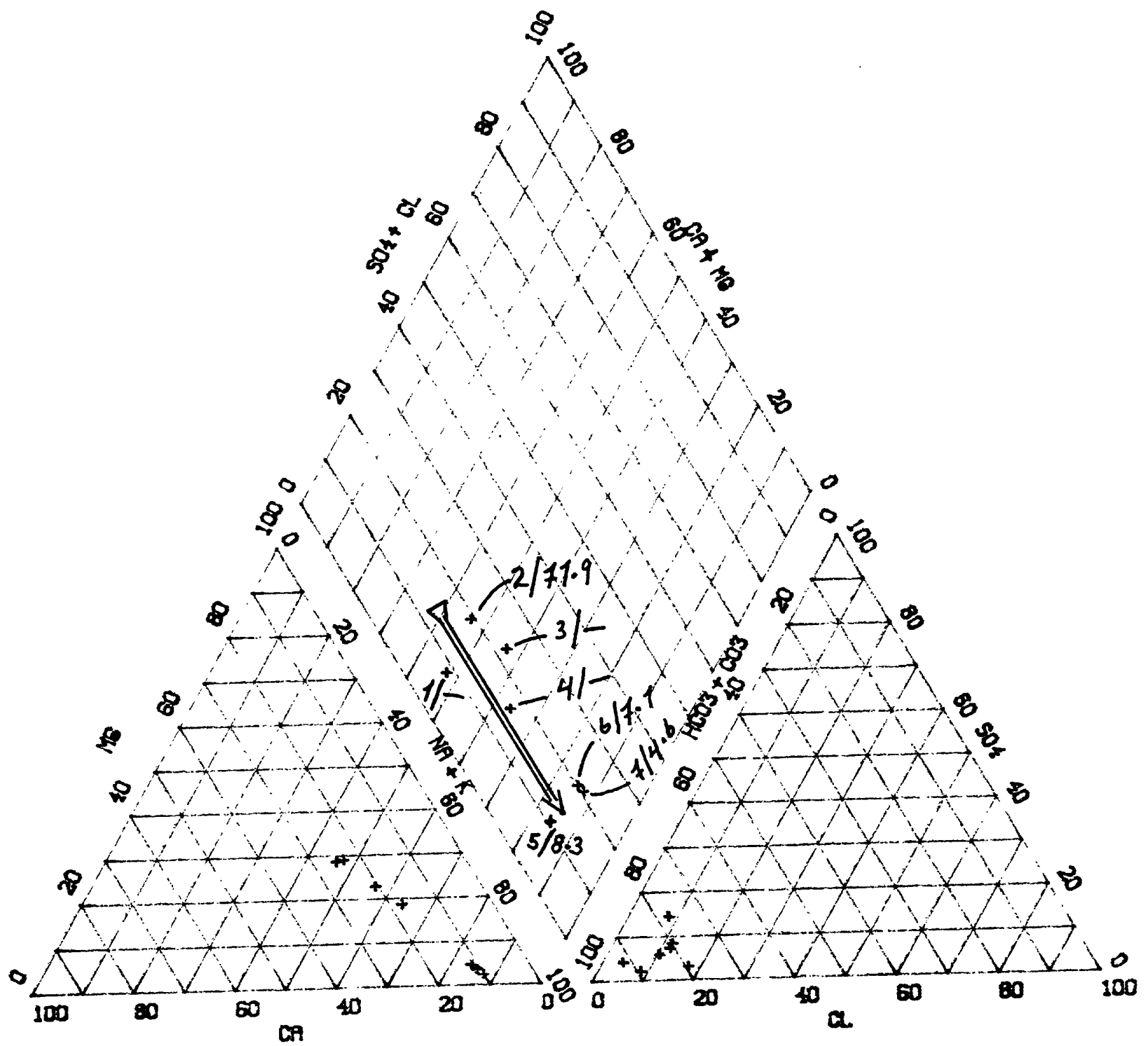

A

EXPLANATION

$2 / 71.9$ First number is site number used in text and table 4. Location of sites is shown on figure 15. Second number is percent of modern carbon in the water

Arrow indicates direction of hydrochemical evolution

Figure 13.--Piper diagrams of ground water from selected wells in the (A) Wanapum unit in the Horse Heaven Hills (data from table 4) and (B) Grande Ronde unit (data from table 6). 


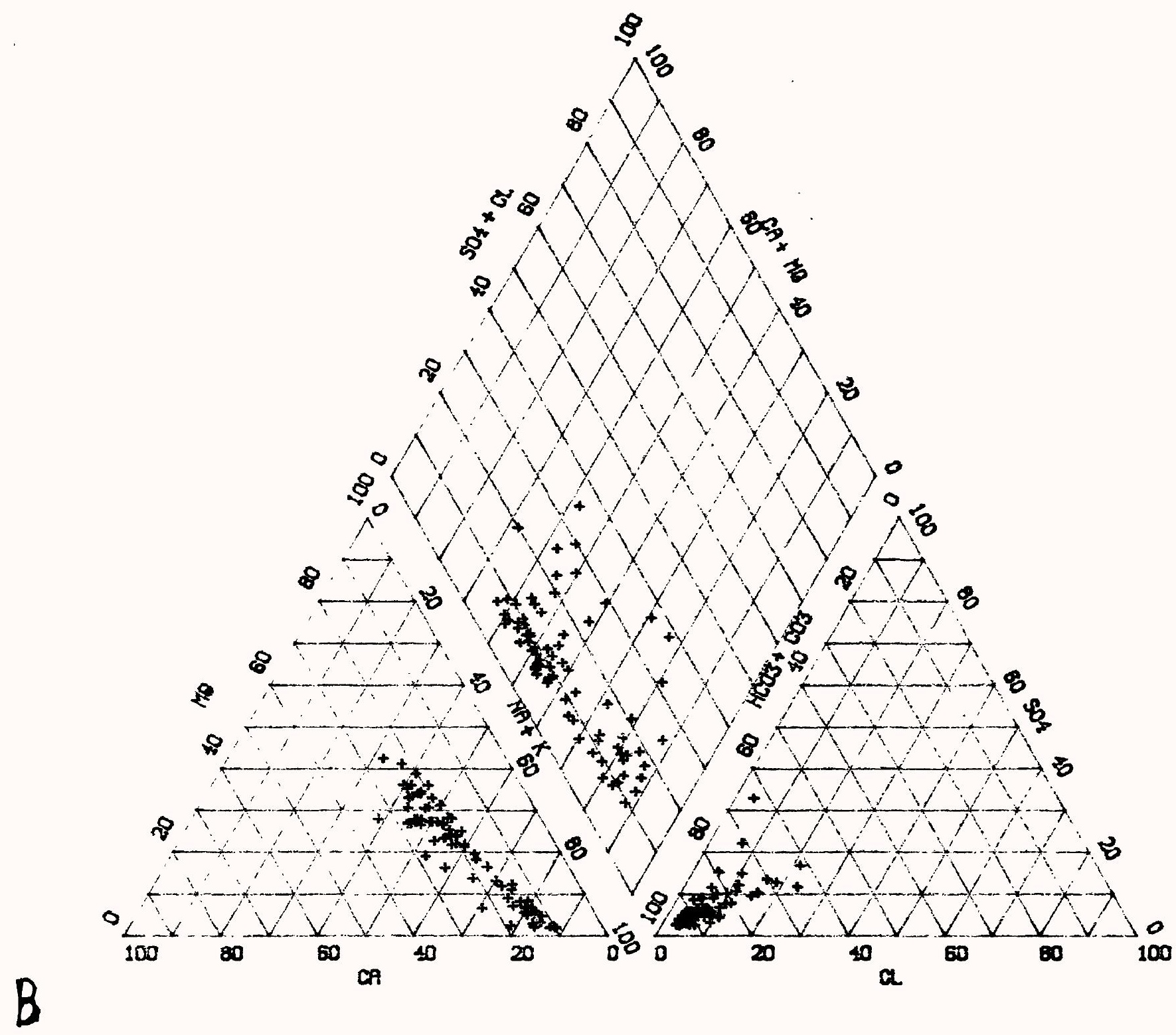

Figure 13.--Continued. 

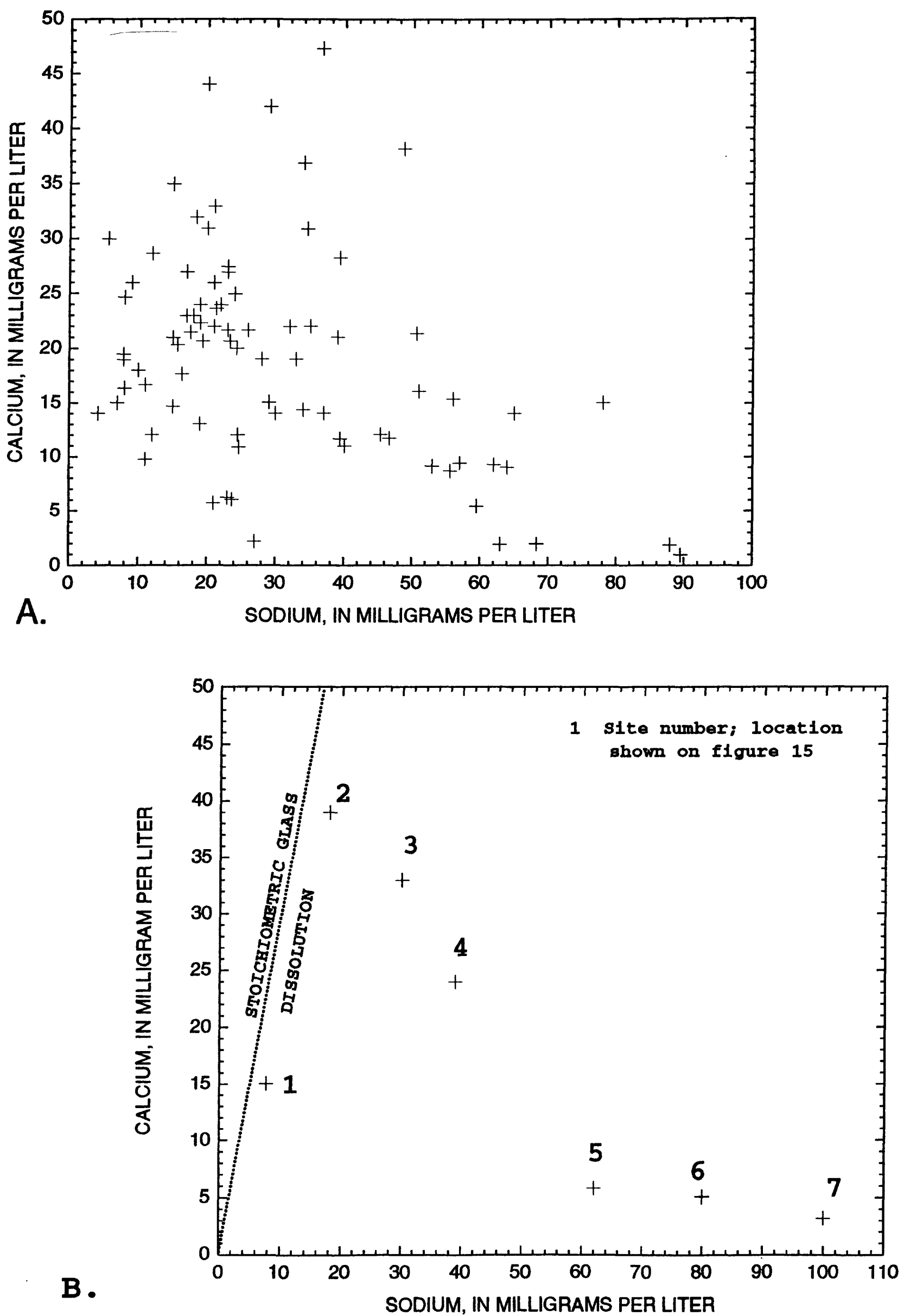

Figure 14.--Relation between averaged calcium and sodium concentrations for (A) the Grande Ronde unit (data from table 6) and (B) selected sites in the Horse Heaven Hills (data from table 4). 


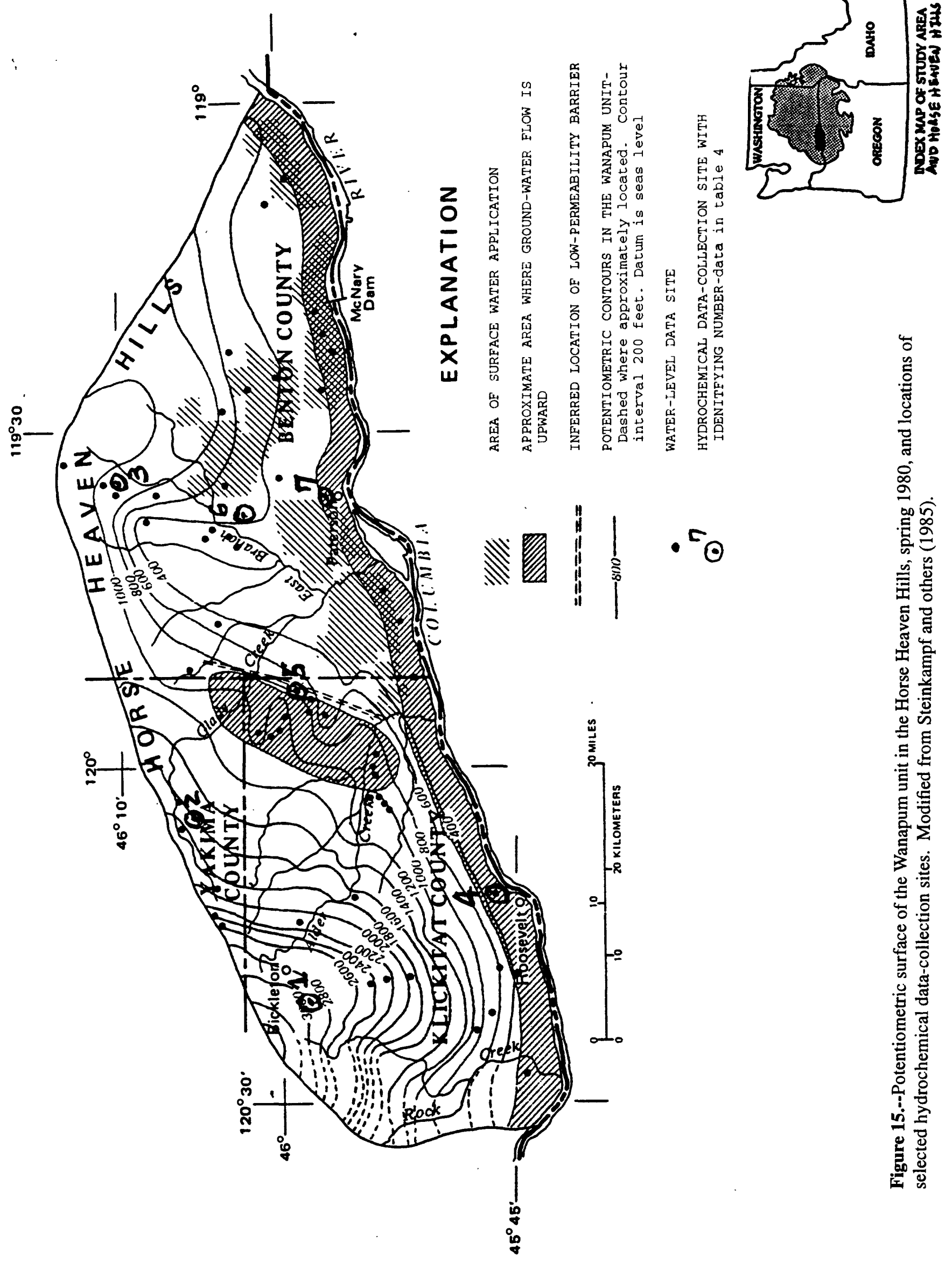



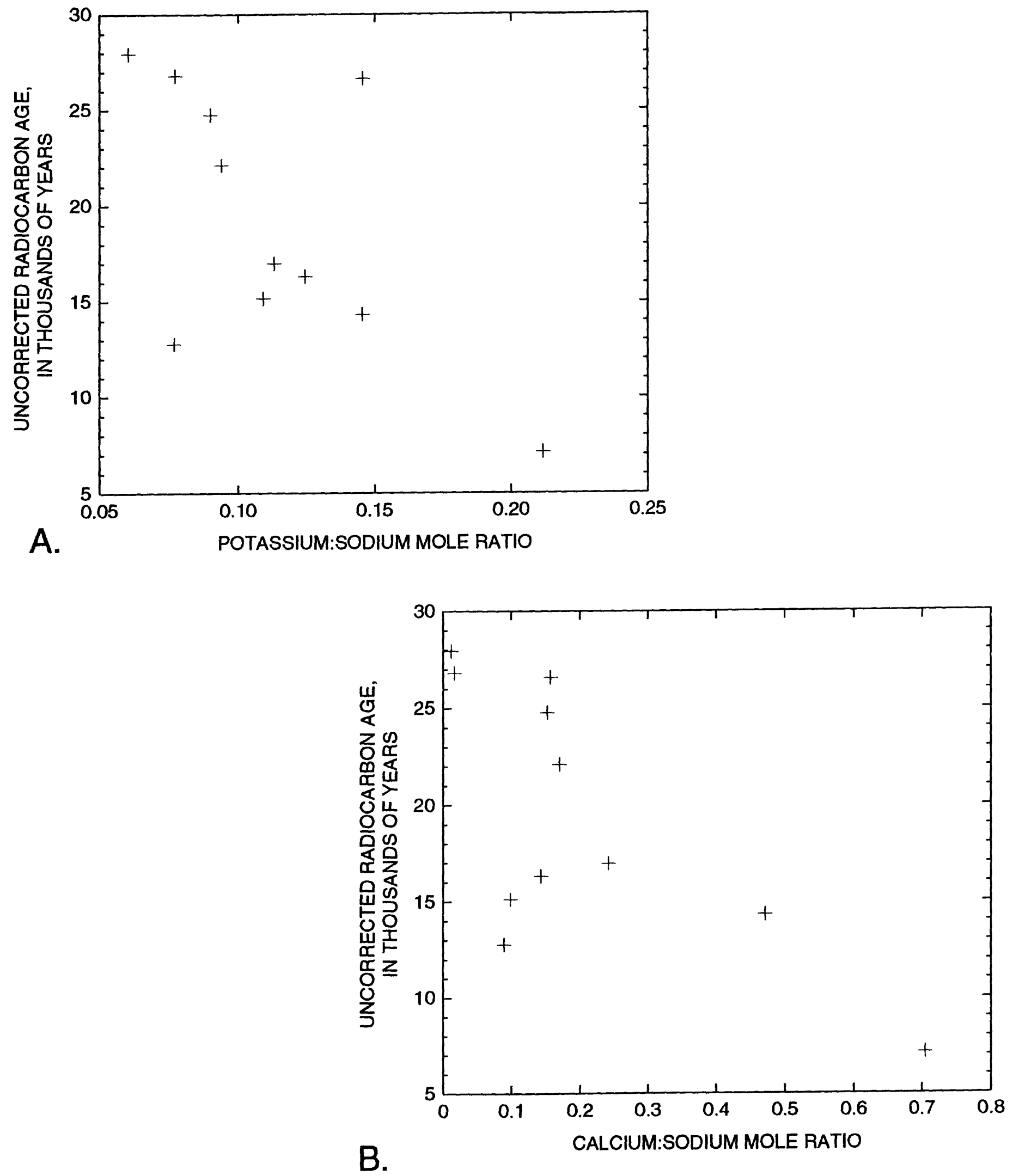

Figure 16.--Relation between averaged uncorrected radiocarbon age and (A) potassium:sodium ratios and (B) calcium:sodium ratios for the Grande Ronde unit. Data from table 6. 


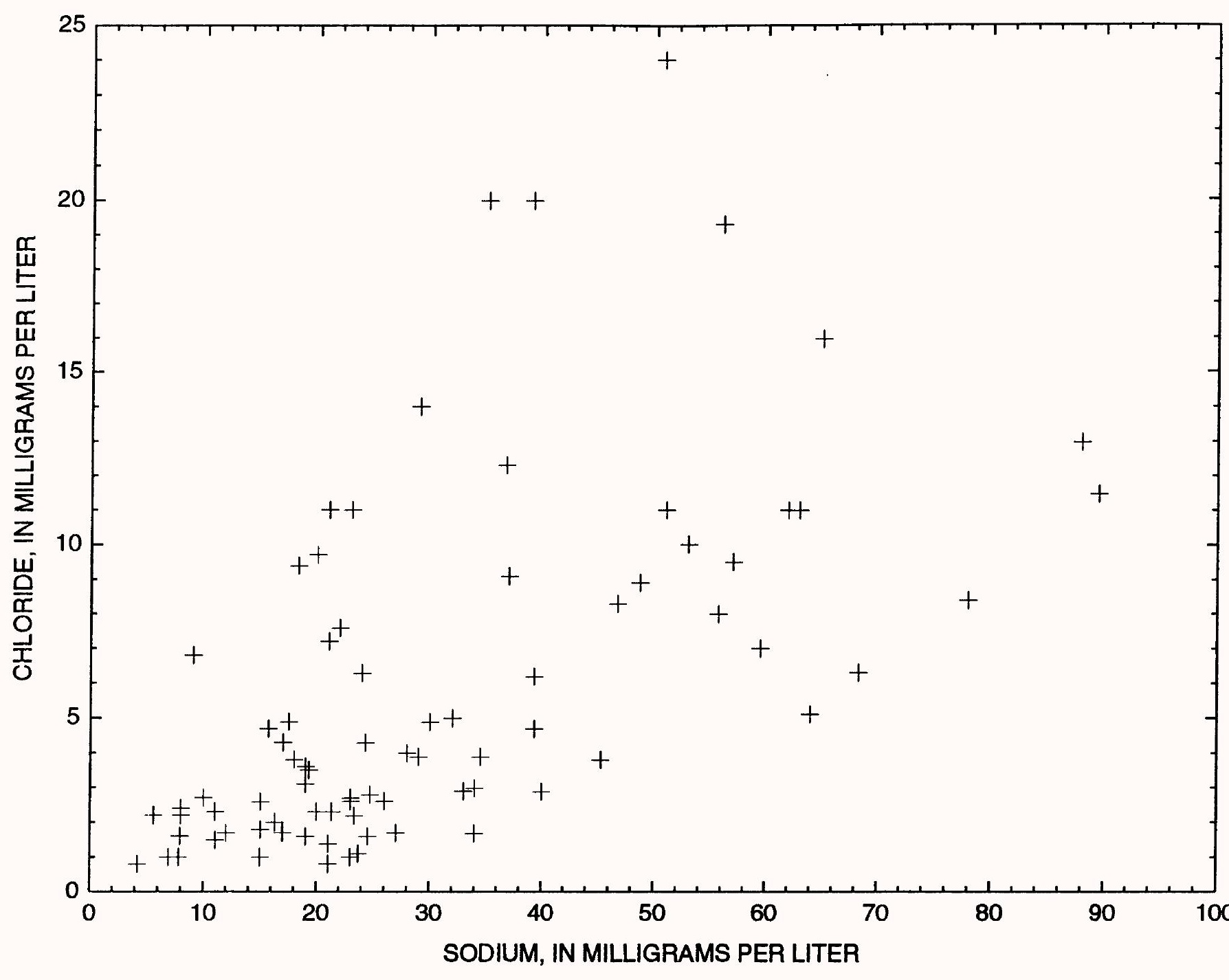

Figure 17.--Relation between averaged chloride and sodium concentrations for the Grande Ronde unit. Data from table 6. 


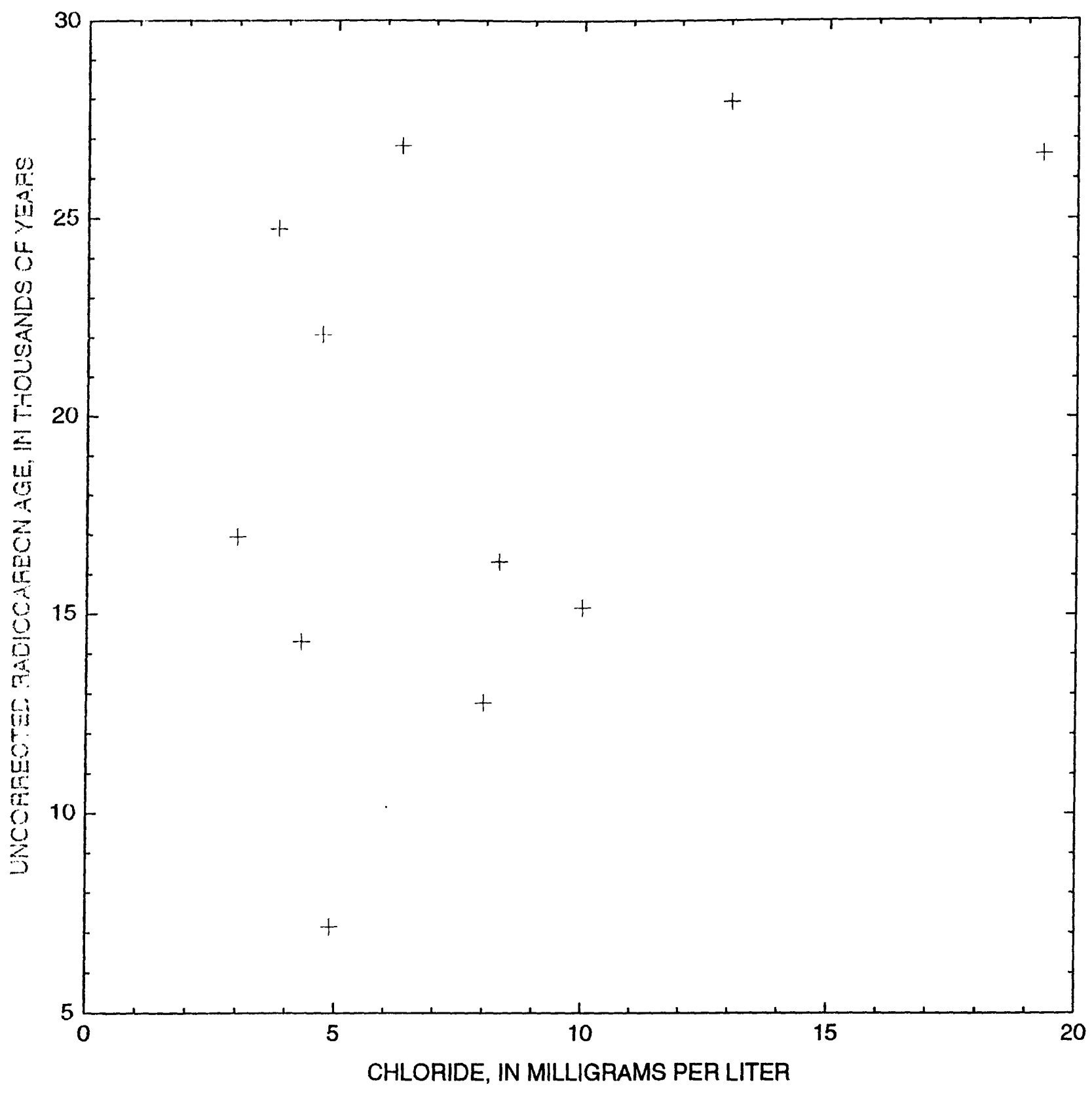

Figure 18.--Relation between averaged uncorrected radiocarbon age and chloride concentration for the Grande Ronde unit. Data from table 6. 
Although $\mathrm{Cl}$ concentrations in rain and snow are small, the semiarid climate probably causes larger $\mathrm{Cl}$ concentration in the soil because of evaporation; this may be an important factor relative to ground-water $\mathrm{Cl}$ concentrations.

Additionally, the climate may affect the accumulation of fertilizer salts in the soil zone; fertilizers are used extensively for agriculture in eastern Washington. Fertilizers have been found to contribute to the hydrochemistry of the ground-water system in some areas (Steinkampf, 1989). The following hypothesis indicates the potential contribution of agricultural $\mathrm{Cl}$ to the ground water. Chloride concentrations in recharge waters transporting agricultural chemicals are a function of the type, frequency, and areal rate of fertilizer application, and the frequency and volume of water applied. The reported weight of potassium chloride $(\mathrm{KCl})$ sold in Washington as agricultural fertilizer from June 15, 1986, through June 14, 1987, was $77,028,000 \mathrm{lb}$ (M. Tucker, Washington State Department of Agriculture, written commun., 1988). Assuming that about 90 percent was applied to the part of eastern Washington underlain by the Columbia River Basalt Group (about 25,000 $\mathrm{mi}^{2}$ ), one can estimate an application rate of about $2.06 \mathrm{lb}$ of $\mathrm{Cl}$ per acre for that 12 -month period. Although some of the $\mathrm{Cl}$ was utilized by crops and some was lost to surface runoff or drainage, most probably remained in the soil and unsaturated zones or was transported to the water table by recharging waters.

If the residual $\mathrm{Cl}$ is completely dissolved by percolating waters, the recharge concentration is solely a function of applied irrigation water that reaches the water table. Assuming that 2 acre- $\mathrm{ft}$ of water is a typical volume applied over a year, that 80 percent of the applied $\mathrm{Cl}$ is available for transport, and that about 1 to 15 percent of the applied water recharges the aquifer system, then $\mathrm{Cl}$ concentrations in the recharging water would range from about 2 to $30 \mathrm{mg} / \mathrm{L}$. However, if 50 percent of the applied $\mathrm{Cl}$ is available, the recharge concentration would range from about 1.3 to $19 \mathrm{mg} / \mathrm{L}$. The regional contribution of $\mathrm{Cl}$ to the ground water from fertilizers thus may be greater than the contribution from precipitation. The same is true for other fertilizer components if they are transported to the saturated zone.

After recharge has occurred, $\mathrm{Cl}$ concentrations in ground-water increase primarily by dissolution of basaltic aquifer materials. Although $\mathrm{Cl}$ analytical data were not available for rocks of the Columbia River Basalt Group, Wood and Low $(1986$, p. 1,460) reported that "finely ground, oven-dried, fresh, flow top vesicular basalt" from the eastern Snake River Plain in Idaho yielded $220 \mathrm{ppm}$ (parts per million) $\mathrm{Cl}$ when leached with nitric acid (experimental conditions not reported). This concentration is similar to the mean $\mathrm{Cl}$ concentration (192 ppm) reported by Sigvaldason and Oskarsson (1976) for basalt in the rift zone in the northeastern Iceland.

Rock dissolution rates were calculated using the yield reported by Wood and Low (1986) and the $\mathrm{Cl}$ and radiocarbon data pairs for four sites in the Horse Heaven Hills (sites 2, 5, 6, and 7; figure 15 and table 4). These rates ranged from about 2 to $25 \mathrm{~g} / \mathrm{ka}$ (grams per thousand years). The four calculated rates and radiocarbon ages for two Grande Ronde unit sites (sites 25 and 45, table 6) on a flow line were then used to estimate $\mathrm{Cl}$ concentrations in water from these two sites. Comparisons of the estimated and measured concentrations are shown on figure 19. The best and worst estimates were those based on the dissolution rates for site $5(2 \mathrm{~g} / \mathrm{ka})$ and site $2(25 \mathrm{~g} / \mathrm{ka})$, respectively. The $\mathrm{Cl}$ concentrations estimated using the rate from site 5 most closely match the actual $\mathrm{Cl}$ concentrations for the Grande Ronde unit, and those estimated using the rate from site 2 exceeded the measured values by as much as an order of magnitude. Using the rate from site 6 gave a good estimate of the $\mathrm{Cl}$ concentration for younger Grande Ronde unit waters, but overestimated the concentration in older waters by a factor of about 1.5 . Chloride concentrations for both younger and older waters were overestimated (factors of 1.6 and 2.4, respectively) when the rate from site 7 was used. On the basis of the above, a rate of about $2 \mathrm{~g} / \mathrm{ka}$ appears to be the best estimate for basalt dissolution. Factors that may account for the large rates calculated for sites 7 and 2 are described below.

Site 7 of the Horse Heaven Hills data pairs is the most downgradient well (fig. 15); it is near the Columbia River and near the crest of an anticline. Steinkampf and others (1985) described the site as a Saddle Mountains unit well, but noted that relative solute concentration in the unit's water resembled that within the Wanapum unit. Re-examination of drilling records suggests that the well is completed in the uppermost part of the Wanapum unit (A.J. Hansen, Jr., U.S. Geological Survey, oral commun., 1990). This general location, along the Columbia River, is one at which ground-water flow has a large vertically upward component (Packard and others, U.S. Geological Survey, written commun., 1984) and is in an area of surface-water irrigated agriculture. These factors combine to yield the relatively large and anomalous solute concentrations present in water from this well. The upward flowing water is more evolved than could be expected from water in the Saddle Mountains unit at this location, and also appears to have larger concentrations of $\mathrm{Ca}, \mathrm{Mg}, \mathrm{K}, \mathrm{SO}_{4}$, and $\mathrm{Na}$. These larger concentrations are consistent with data from other wells that are in areas in the Horse Heaven Hills where surface water is applied (Steinkampf and others, 1985). 

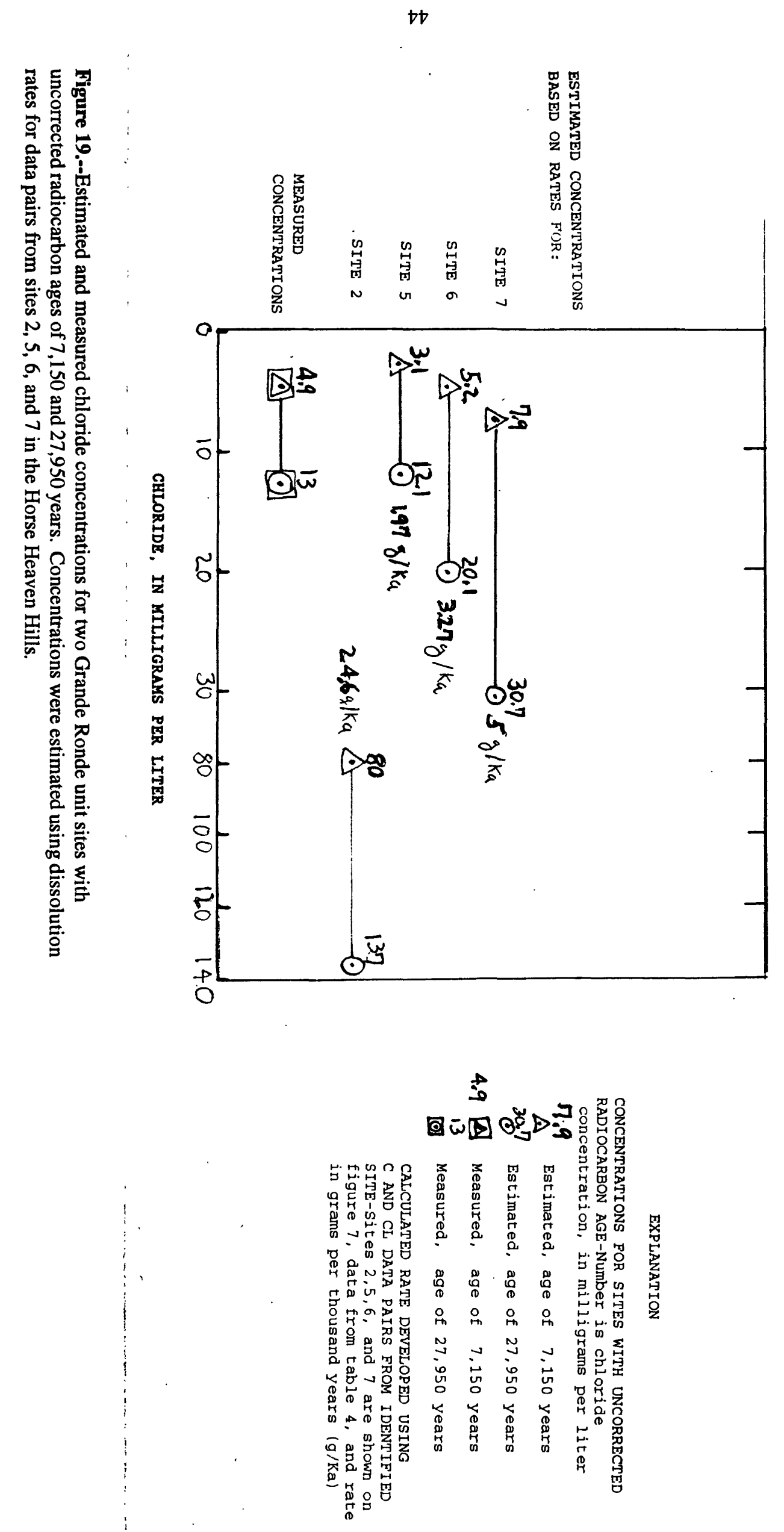
The dissolution rate calculated for site $2(24.6 \mathrm{~g} / \mathrm{ka})$ was the largest. Examination of the $\mathrm{Cl}$ and $\mathrm{Na}$ data for the Horse Heaven Hills (fig. 20) shows that the $\mathrm{Cl}$ value at site 2 is not in accord with the rest of the Horse Heaven Hills data. Site 2 is on the southern slope of the Glade Creek valley near the crest of the Horse Heaven Hills (fig. 15). It is adjacent to a residence that is surrounded by farmed land, the altitude of which is higher than the Wanapum unit water levels. The Wanapum unit is at or near land surface, and the primary direction of ground-water flow in this area is downward to and within the Wanapum unit (Packard and others, U.S. Geological Survey, written commun., 1984). A highway in this area follows Glade Creek. It is probable that the creek recharges the Wanapum unit and that agricultural and highway drainage contribute to the $\mathrm{Cl}$ concentration in the aquifer unit. In addition to the large $\mathrm{Cl}$ concentration, ground-water from the site also had a dissolved $\mathrm{N}$ concentration of $1 \mathrm{mg} / \mathrm{L}$.

The conceptual model proposed by Hearn and others (1985) incorporates the hydrolysis of basaltic glass as the primary dissolution mechanism in the aquifer system. Hydrolysis dissolution results in increasing ground-water $\mathrm{pH}$ and solute concentration with residence time in the aquifer system. Data from both the Grande Ronde unit and Horse Heaven Hills indicate increasing $\mathrm{pH}$ with increasing evolution, as inferred from $\mathrm{Na}$ concentrations

(fig. 21). Both data sets show a gradual $\mathrm{pH}$ rise, from initial values of about 7.2 to values as much as 9.4. The $\mathrm{pH}$ of the average precipitation in the Cascade Range in Washington, calculated from data in Laird and others (1986), is 5.46. Dissolution of soil $\mathrm{CO}_{2}$ by recharging meltwaters would lower their $\mathrm{pH}$, possibly by as much as 2.5 units lower than that of the least evolved waters shown on figure 21. The large observed values of $\mathrm{pH}$ thus suggest that the concentration of soil and (or) atmospheric $\mathrm{CO}_{2}$ may be small or the system may be closed. The lowering of $\mathrm{pH}$ and dissolved inorganic carbon concentrations can be described by the dissociation of water $(\mathrm{HOH})$

(eq. 1), and the dissolution and subsequent dissociation of $\mathrm{CO}_{2}$ (eqs. 2-4), as follows:

$$
\begin{gathered}
\mathrm{HOH}=\mathrm{H}^{-}+\mathrm{OH}^{-} \\
\mathrm{CO}_{2}+\mathrm{HOH}=\mathrm{H}_{2} \mathrm{CO}_{3} . \\
\mathrm{H}_{2} \mathrm{CO}_{3}=\mathrm{H}^{+}+\mathrm{H}_{2} \mathrm{CO}_{3}^{-} \\
\mathrm{HCO}_{3}^{-}=\mathrm{H}^{+}+\mathrm{CO}_{3}^{2-} .
\end{gathered}
$$

The extent of the contribution of soil and (or) atmospheric $\mathrm{CO}_{2}$ to the aquifer system can be inferred from the concentrations of dissolved $\mathrm{CO}_{2}$, expressed as partial pressure $\left(\mathrm{PCO}_{2}\right)$ in Grande Ronde unit waters. Partial pressures (fig. 22) calculated using the chemical equilibrium model of Plummer and others (1976) in nearly all of the waters greatly exceeds the atmospheric concentrations. This indicates that either the aquifer system is open to the soil and (or) atmosphere throughout much of the study area, or there is a significant carbon reservoir within the basalts.

Areal variation of isolation within the aquifer system is principally due to the highly variable extent and thickness of the overburden, Saddle Mountains unit, and Wanapum unit. In areas where the thickness of materials overlying the Grande Ronde unit is sufficient to preclude a large downward vertical flux, the downward travel time of recharging waters is more than the reaction time required to reduce the $\mathrm{PCO}_{2}$ to or below an atmospheric level.

The negative slopes of relations between $\mathrm{PCO}_{2}$ and $\mathrm{pH}$ within each range of $\mathrm{Na}$ concentrations (fig. 22a) indicate that, although waters are at different evolutionary stages, they follow similar trends. This further indicates that the waters became isolated from the atmosphereunsaturated zone at different evolutionary stages and that isolation has little or no relation to residence time in the system, suggesting the presence of a large amount of carbon within the Grande Ronde unit. A combination of the above factors appears to account for the similar $\mathrm{pH}-\mathrm{CO}_{2}$ trends.

Smiley (1963) presented paleobotanical evidence for a warm, humid climate, with as much as $\mathbf{5 0 ~ i n / y r ~ o f ~ r a i n - ~}$ fall for the Columbia Plateau during the Miocene to early Pliocene time. These conditions were conducive to profuse vegetation and the accumulation of large amounts of organic detritus between Grande Ronde Basalt eruptive periods. Raymond and Tilson (1968) reported the presence of coal between depths of 2,000 and 5,000 ft in a deep exploratory hole drilled in the northern part of the Hanford Reservation. They presented palynological evidence for the existence of a temperate to perhaps subtropical swamp and adjacent hardwood forests in Miocene time. Subsequent re-examination of the organic material revealed it to be peat and not coal (S.P. Reidel, oral commun., 1989). This type of material, if present throughout the Grande Ronde unit, can provide a large amount of oxidizable organic carbon and nitrogen to the ground-water system. 


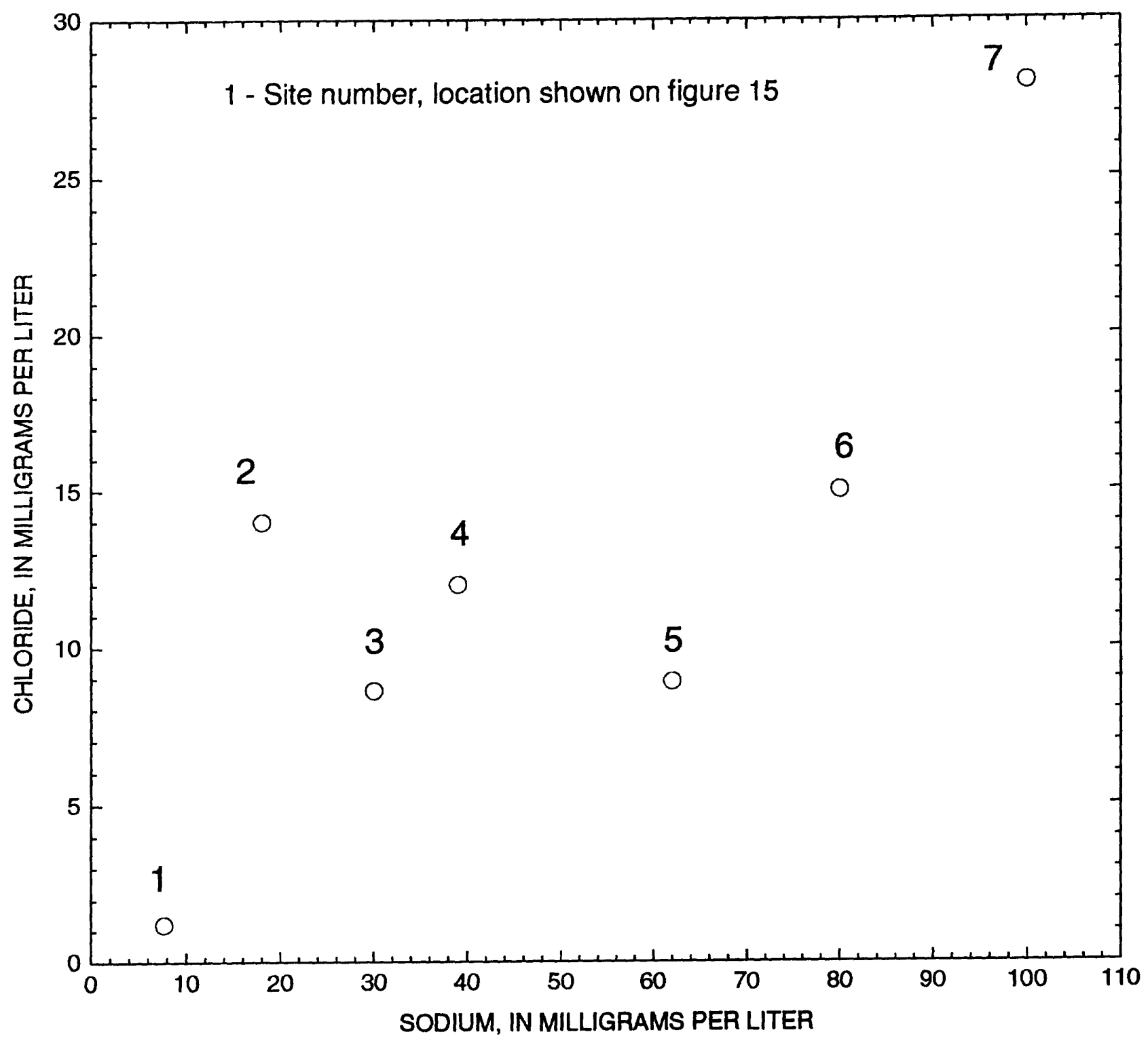

Figure 20.--Relation between chloride and sodium concentrations for selected sites in the Horse Heaven Hills. Data from table 4. 


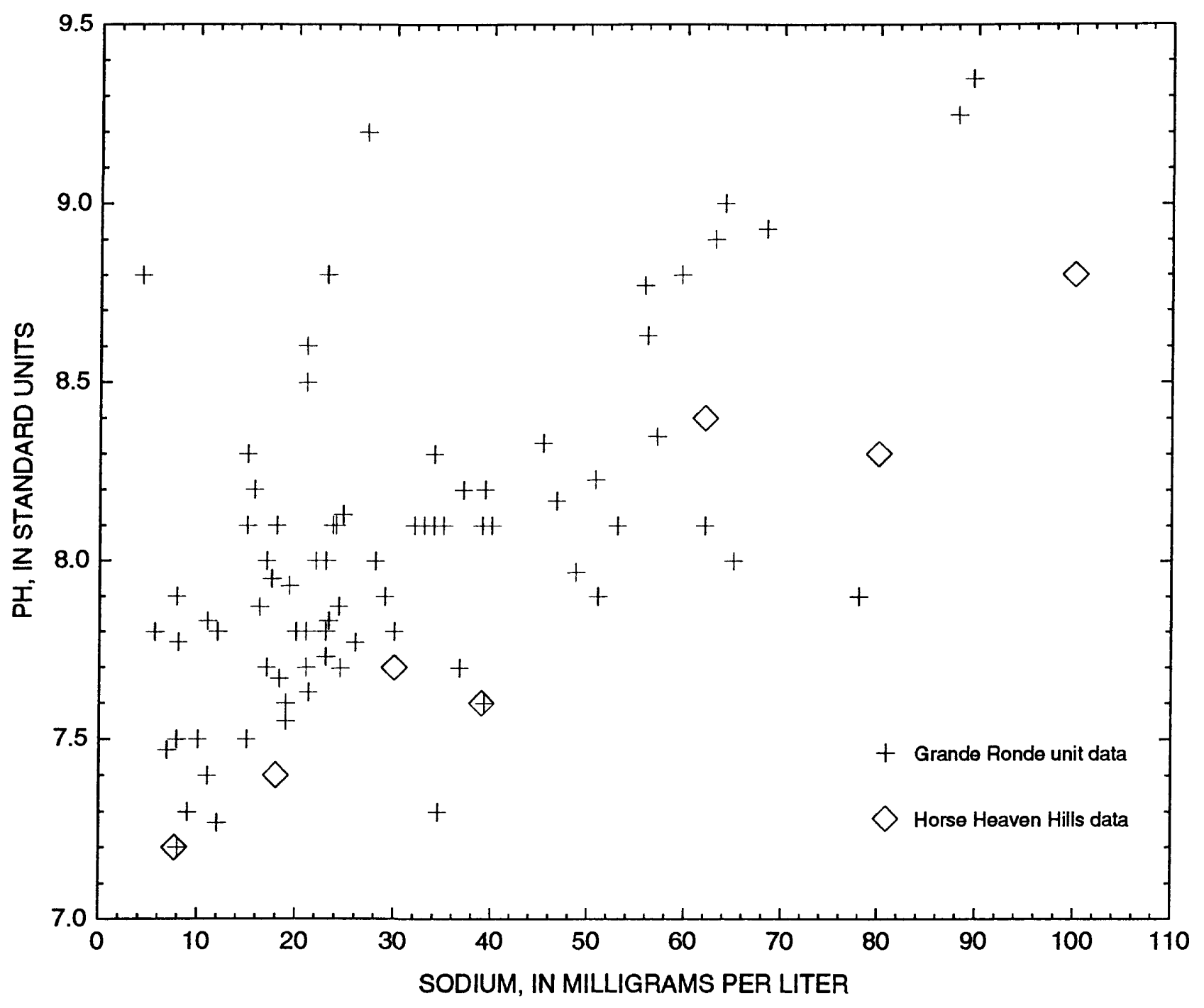

Figure 21.--Relation between $\mathrm{pH}$ and sodium concentrations for the Grande Ronde unit (data from table 6) and selected sites in the Horse Heaven Hills (data from table 4). 


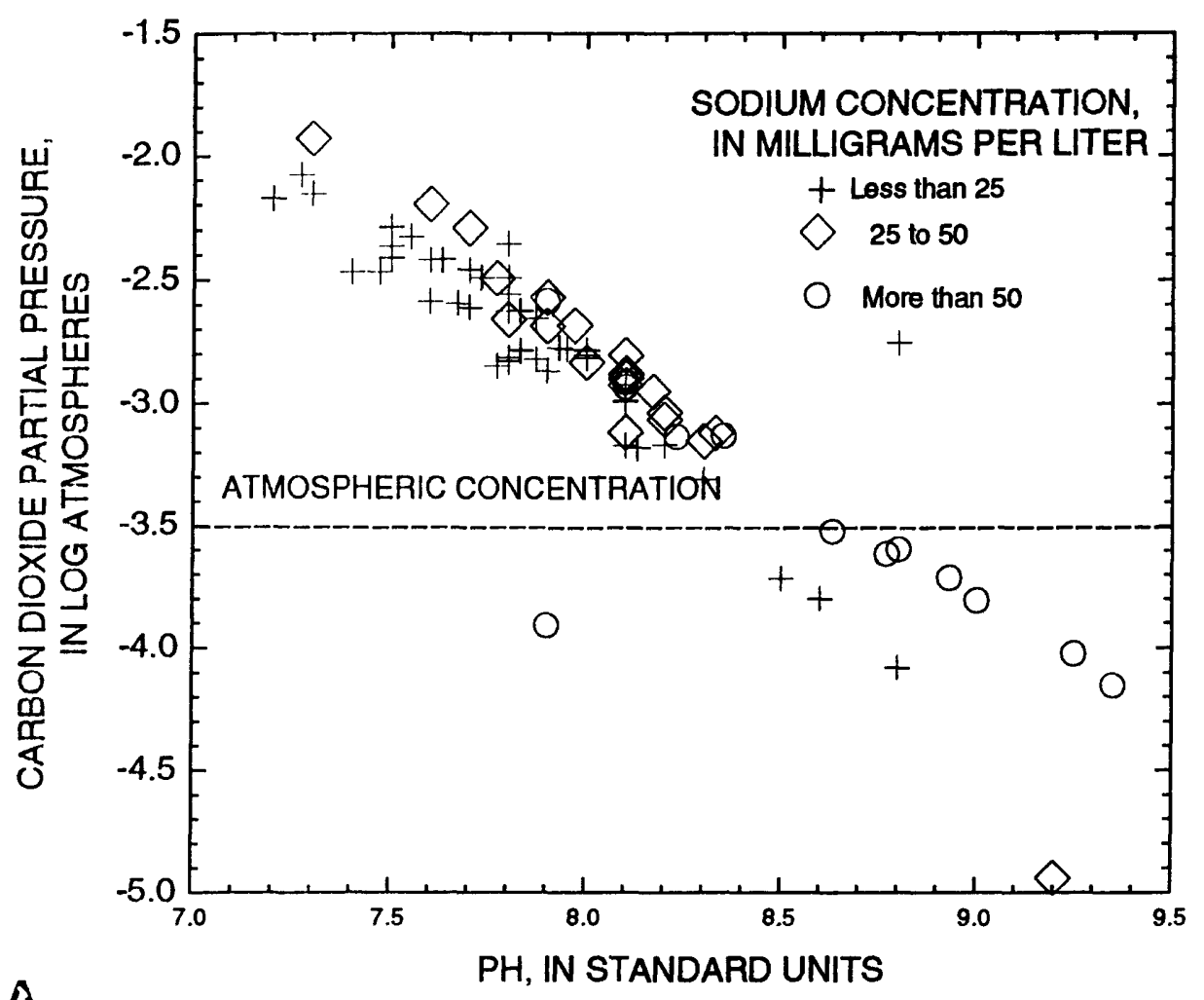

A.

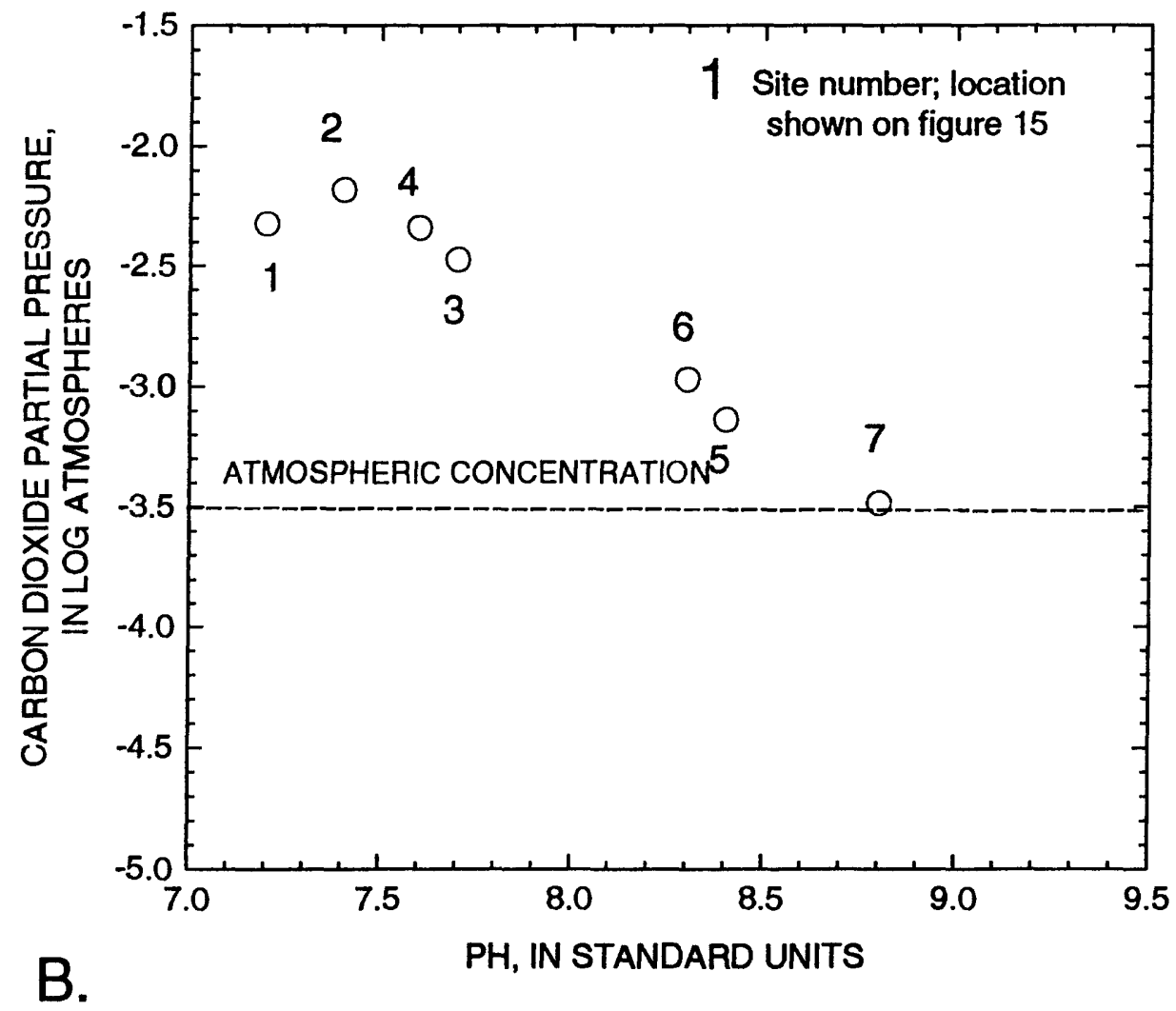

Figure 22.--Relation between carbon dioxide partial pressure and $\mathrm{pH}$ for (A) the Grande Ronde unit (data from table 6) and (B) the Horse Heaven Hills (data from table 4). 
Another factor that can contribute to below-atmospheric $\mathrm{PCO}_{2}$ values is a short residence time in the soil zone, which would result in low initial values. This appears to be the case for the lowest $\mathrm{PCO}_{2}$ value on figure 22a. This site is a 1,150-ft deep well located in the Blue Mountains of Oregon. It is at an altitude of $2,750 \mathrm{ft}$, in the northwestern part of the Grande Ronde River valley, about $4 \mathrm{mi}$ from the west valley wall. Land-surface altitudes in the surrounding mountains are as much as $3,600 \mathrm{ft}$ higher than the valley floor. The $\mathrm{Na}$ concentration at this site is $27 \mathrm{mg} / \mathrm{L}$, slightly less than the mean for the Grande Ronde unit of $28 \mathrm{mg} / \mathrm{L}$; the $\mathrm{PCO}_{2}$ is nearly 1.5 orders of magnitude below atmospheric levels. Although these values appear to be unusual and an error in the field-pH determinations could be responsible for a low value of $\mathrm{PCO}_{2}$ (as the partial-pressure calculation is sensitive to the hydrogen activity), they are similar to those at a nearby site $\left(1,458 \mathrm{ft}\right.$ deep, $23 \mathrm{mg} / \mathrm{L}$ of $\left.\mathrm{Na}, \log \left(\mathrm{PCO}_{2}\right)=4.1\right)$, indicating that the data are current. A reasonable explanation is that these samples represent water that recharged the aquifer system before it had sufficient contact with the soil zone to dissolve much $\mathrm{CO}_{2}$. The ground-water recharge probably was derived from surface runoff in the adjacent mountains where the relief is such that, prior to recharge, rainfall and snowmelt probably have a short residence time in the thin soil zones in these areas. A lack of a significant reservoir of oxidizable carbon in this location could account for a low value of $\mathrm{PCO}_{2}$.

\section{Secondary Mineral Controls} glass is

A simplistic reaction for the dissolution of basaltic

$$
\begin{aligned}
\text { glass } & +n H O H=n O H \\
& + \text { 'dissolved glass components } \\
& + \text { 'secondary phases' }
\end{aligned}
$$

The attendant consumption of $\mathrm{H}$ ions in this reaction tends to drive the reaction in equations 1 to 4 to the right, resulting in increased concentrations of $\mathrm{CO}_{3}{ }^{2-}, \mathrm{OH}^{-}$, and the elements composing the glass. As the reaction products accumulate in solution, the concentration increases and, with the increasing $\mathrm{pH}$, results in an environment conducive to the precipitation of insoluble reaction products or secondary minerals. This general reaction scheme controls the accumulation of dissolved materials in solution, as can be seen from the relation between dissolved solids and $\mathrm{Na}$ (fig. 10). If no dissolved components were removed as the glass dissolution reactions progressed, the slope of the relation would be about 52 instead of about 6 and all elemental concentrations would be proportional to their abundances in the glass.

The first solid phases to form probably are $\mathrm{Al}$ and $\mathrm{Fe}$ compounds. These elements compose 24.7 mole percent of the basaltic glass and, under the chemical and thermal conditions of the plateau, are among the least soluble glass components in the basalts. The precipitates formed are likely amorphous $\mathrm{Fe}$-rich aluminosilicates and amorphous $\mathrm{Fe}$ oxyhydroxides. It is unlikely that the well-ordered clays found in the basalts precipitate directly from solution; their structural and compositional complexity (table 1) suggest that this is not kinetically feasible. It is more probable that they result from an increase in structural ordering over time, from what Paces (1973) called "an amorphous isoelectric solid", and that aging also includes adsorption and octathedral and tetrahedral substitutions in this non-ideal phase. This is substantiated by the widespread occurrences of nontronitic smectite and $\mathrm{Fe}$ oxides in drill cores and cuttings from throughout the plateau (Ames, 1980; Benson and Teague, 1982; Hearn and others, 1985). It also is consistent with the experimental work and field observations of Icelandic basalts (Gislason and Eugster, 1987a,b). Deutsch and others (1982), on the basis of equilibrium calculations using the model of Ball and others $(1979,1980)$, stated that although clay minerals generally were oversaturated with respect to ground waters in the Pasco Basin, they estimated that "amorphous-like" $\mathrm{Fe}, \mathrm{Al}$, and Si phases probably are the most important controls on $\mathrm{Fe}, \mathrm{Al}$, and $\mathrm{Si}$ concentrations.

Amorphous $\mathrm{Fe}$ oxides derive from the ferrous $\mathrm{Fe}$ present in basaltic glass. The dissolved $\mathrm{Fe}$ is oxidized to ferric $\mathrm{Fe}$ by $\mathrm{DO}$, if present, and rapidly precipitates as an oxyhydroxide. The structure of this material probably also becomes more ordered with time (Langmuir and Whittemore, 1971). Dissolved oxygen is present in most ground waters throughout the plateau (table 2), and its occurrence and concentration at a particular site appear to be related to position in the flow path and to the distribution and thickness of the overburden along the flow path. This latter relation is most applicable to water in the Saddle Mountains unit (Steinkampf, 1989). Although DO concentrations in the Grande Ronde unit range from 0.1 to about $10 \mathrm{mg} / \mathrm{L}$ with a mean of $2.6 \mathrm{mg} / \mathrm{L}$ (table 6 ), concentrations of DO of more than about $2 \mathrm{mg} / \mathrm{L}$ are almost always found in outcrop areas. For those sites having dissolved $\mathrm{N}$ concentrations below $1.0 \mathrm{mg} / \mathrm{L}$, the mean $\mathrm{DO}$ value is about $1.6 \mathrm{mg} / \mathrm{L}$; most of the averaged $\mathrm{DO}$ values within this data set are below $1 \mathrm{mg} / \mathrm{L}$ (fig. 23 and table 6). However, some relatively deep waters appear to have large DO concentrations (fig. 23). 


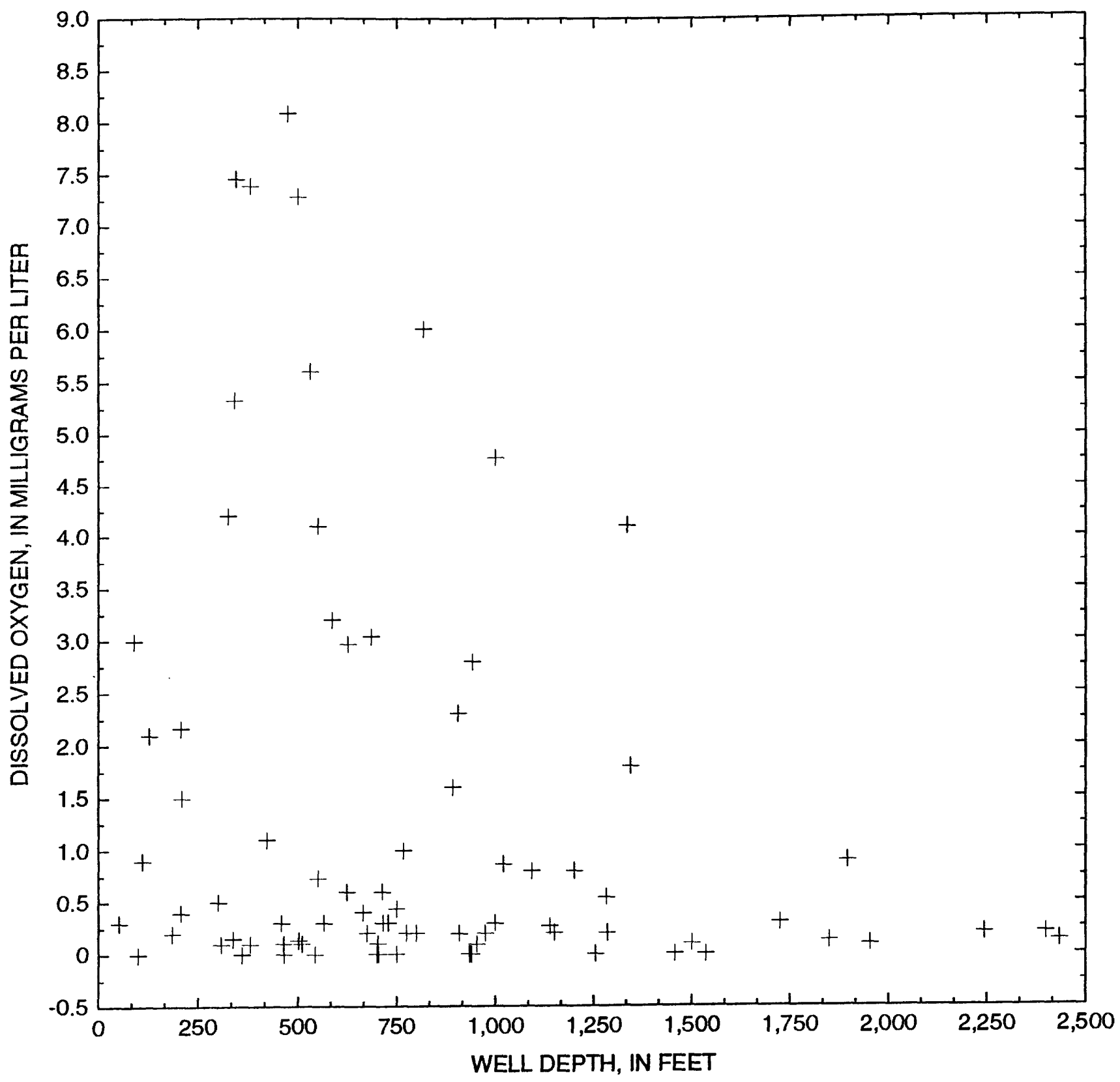

Figure 23.--Relation between averaged dissolved-oxygen concentration and well depth for the Grande Ronde unit. Dáta from table 6. 
Ames (1980) briefly discussed the relatively sparse occurrence of amorphous $\mathrm{Fe}$ oxides in the cores he examined. Hearn and others (1984) examined cuttings from a depth range of 279 to $4,726 \mathrm{ft}$ and found Fe oxides only at depths less than $984 \mathrm{ft}$. Iron oxides generally were found to be admixed with nontronitic smectite, such that they generally could not be distinguished either visually or analytically from the smectites present. This was further shown by the unrealistic calculated stoichiometry of primarily shallow smectites (Hearn and others, 1985). Although most waters in this study were calculated to be oversaturated with amorphous ferric hydroxide, $\mathrm{Fe}\left(\mathrm{OH}_{3}\right)$, the reliabilities of the available thermodynamic and Eh data (calculated from DO concentrations and two sulfide-sulfate couples) are such that a definitive statement cannot be made concerning this oversaturation. It can be noted, however, that waters in or near recharge areas appear to be undersaturated, and that calculated saturation indices (SI, the log IAP/KT or logarithm of ion activity product/equilibrium constant) increase down flow paths.

The occurrences of concentrations in milligrams per liter (table 2) suggest that organic Fe complexes may be important geochemical controls and should be considered in a more rigorous examination of dissolved $\mathrm{Fe}$ and the stability of secondary Fe phases.

Secondary Si phases have been reported to be widespread both vertically and areally in the basalts. Silica is commonly intimately associated with clays, Fe oxyhydroxides, and other secondary phases, and is present as quartz, cristobalite, tridymite, and opal-CT (Benson and Teague, 1982). Ames (1980) reported the presence of quartz throughout all of the cores he examined, whereas other Si phases were less abundant. The cores he examined spanned vertical intervals from near land surface to depths of about $4,920 \mathrm{ft}$. Hearn and others (1985) did not observe discrete $\mathrm{Si}$ in samples from depths shallower than about $1,475 \mathrm{ft}$.

The states of saturation of Grande Ronde unit waters and Wanapum unit waters in the Horse Heaven Hills with respect to various $\mathrm{Si}$ phases are shown on figure 24 . The figure shows that all are oversaturated with respect to chalcedony and $\alpha$-cristobalite and undersaturated with respect to the less crystalline, and more soluble, phases. A quartz solubility line for the temperature range used on figure 24 would have left and right $y$-axis intercepts of about -4.3 and -3.8 , respectively, strongly supporting the implication by Benson and Teague (1982) that the quartz reported by Ames (1980) is instead a less-ordered and more soluble phase, such as chalcedony or $\alpha$-cristobalite.
Gislason and Eugster (1987b) suggested that the activity of $\mathrm{Si}$ in basaltic glass controls dissolved $\mathrm{Si}$ concentrations in the Icelandic ground waters they sampled. An extrapolation of their basaltic glass solubility data ( 0 to $10^{\circ} \mathrm{C}$ ) to plateau ground-water temperatures approximates the $\alpha$-cristobalite solubility curve (fig. 24). Although the basaltic glass composition used in this study has a slightly larger Si concentration and is therefore slightly less soluble than the Icelandic glasses, the large Si concentrations in the plateau ground waters, relative to the Icelandic spring and melt waters, are attributable to the higher water temperatures in the Columbia River Basalt Group.

An aspect of the Si data that is not apparent without the results of equilibrium calculations is the consistent downgradient decreases of SI's for Si phases. This was noted for flow paths in the Grande Ronde unit and in the Wanapum unit in the Horse Heaven Hills. The downgradient decrease is attributed to higher water temperatures and it also suggests that another solid phase (or phases) influences $\mathrm{Si}$ concentrations as ground-water ionic strengths increase. One such possibility is adularia $\left(\mathrm{KAlSi}_{3} \mathrm{O}_{8}\right)$, a feldspar reported as a secondary mineral in deposits associated with vitric volcanic material (Hay and others, 1986). Ames (1980) used X-ray diffraction data for samples of altered basalts from five drill holes to show the presence of feldspar (unidentified). Where $\mathrm{Al}$ data are available, calculated SI's for adularia increase from negative to positive at sites along the Horse Heaven Hills flow path. Saturation indices for the 12 Grande Ronde unit sites for which $\mathrm{Al}$ data are available are more than 1.0 and have a mean of about 1.6.

Zeolites have been reported as one of the abundant types of secondary minerals in the Columbia River Basalt Group; reported occurrences have been from depths below 1,180 ft (Ames, 1980; Benson and Teague, 1982; Hearn and others, 1984, 1985). Clinoptilolite, a primarily $\mathrm{Na}$ and $\mathrm{K}$ mineral, is the zeolite most commonly reported, and mordenie becomes more common below depths of about $2,950 \mathrm{ft}$; apparently mordenie is associated with clinoptilolite dissolution (Benson and Teague, 1982). Reliable, accurate, and consistent thermodynamic data are not available for zeolites. As with smectites, compositional and structural information can be used to estimate clinoptilolite forms, either by direct precipitation or incongruent dissolution of a precursor, but only when $\mathrm{Si}, \mathrm{Na}$, and $\mathrm{K}$ activities (thermodynamic concentrations) are more than those of most waters sampled for this study. Some of the samples from water in the Grande Ronde unit may be sufficiently evolved for zeolite precipitation, but this can be neither validated nor verified thermodynamically. 


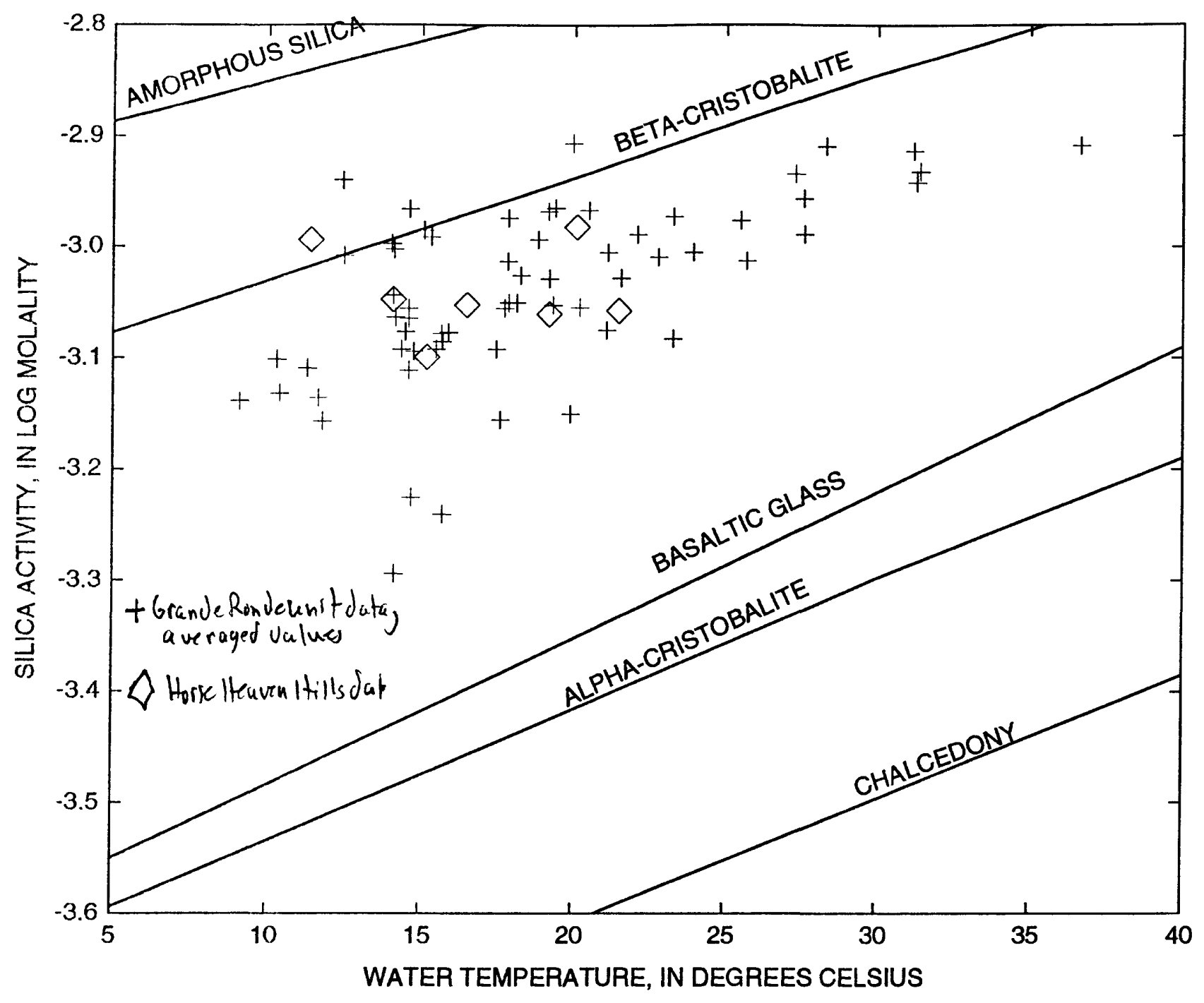

Figure 24.--Relation between calculated dissolved silica activity and ground-water temperature for the Grande Ronde unit (data from table 6) and selected sites in the Horse Heaven Hills (data from table 4). Solubility curves for amorphous silica, beta-cristobalite, alpha-cristobalite, and chalcedony were constructed using equations E, D, C, and B, respectively, from Fournier (1985, p. 60). The curve for basaltic glass was linearly extrapolated from Gislason and Eugster (1987b, figure 6, p. 2, 847). 
Hearn and others (1985) included $\mathrm{CaCO}_{3}$ precipitation in their conceptual model of hydrochemical evolution as a means of removing dissolved $\mathrm{Ca}$ from basaltic ground waters. Although Hearn and others (1984) did not report the observation of calcite in the samples they examined,

Hearn and Steinkampf (1984, unpublished data in U.S. Geological Survey files) observed vesicular $\mathrm{CaCO}_{3}$ in samples from outcrops of Wanapum and Saddle Mountains Basalt from the Horse Heaven Hills and in a core sample from a depth of about $1,280 \mathrm{ft}$ in a Hanford Reservation drill hole. Ames (1980) and Benson and Teague (1982) reported $\mathrm{CaCO}_{3}$ at depths above $1,148 \mathrm{ft}$ and below $3,116 \mathrm{ft}$ in all but one core examined. Additionally, Horton (1985) reported well-crystallized $\mathrm{CaCO}_{3}$ in samples from below $2,625 \mathrm{ft}$ in several cores from the Hanford Reservation.

Calcite occurs primarily as fracture- and vesicle-filling material in the basalts. It is much less abundant than other secondary phases, and likely forms when $\mathrm{pH}$ and concentrations of $\mathrm{Ca}$, and $\mathrm{CO}_{3}$ in ground waters increase beyond $\mathrm{CaCO}_{3}$ stability limits. This occurs generally at $\mathrm{pHs}$ larger than about 8.0 (fig. 25). As ground-water $\mathrm{pH}$ increases to more than 8.0 , equilibrium relations drive the reaction in equation 1 to the left and reactions in equations 2 to 4 to the right. Carbonate becomes the dominant inorganic carbon species in solution, and as hydrolytic dissolution drives the $\mathrm{pH}$ beyond about 8.3 , the inorganic carbon reservoir can no longer effectively buffer the increasing $\mathrm{OH}^{-}$concentration. Subsequent $\mathrm{pH}$ buffering includes the dissociation of dissolved Si species, according to the following:

$$
\begin{gathered}
\mathrm{H}_{4} \mathrm{SiO}_{4}=\mathrm{H}_{3} \mathrm{SiO}_{e}^{-}+\mathrm{H}^{+} . \\
\mathrm{H}_{4} \mathrm{SiO}_{4}^{-}=\mathrm{H}_{3} \mathrm{SiO}_{e}^{2-}+H^{+} .
\end{gathered}
$$

The buffering capacity of dissolved $\mathrm{Si}$, however, is most important at pH's above about 9.0. Examination of $\mathrm{PCO}_{2}$ values and $\mathrm{Si}$ activities for the Horse Heaven Hills sites (fig. 26) leaves open to question whether these waters have evolved sufficiently for buffering of $\mathrm{pH}$ increases by dissolved $\mathrm{Si}$ species to be an important reaction.

In the early stages of hydrochemical evolution, $\mathrm{Ca}$ concentrations increase nearly linearly (see fig. 14) until the $\mathrm{pH}$ has increased to a point at which sufficient $\mathrm{HCO}_{3}$ dissociation (eq. 4) results in a $\mathrm{CO}_{3}$ concentration such that the IAP of $\mathrm{CaCO}_{3}$ equals or exceeds the equilibrium value of the attendant water temperature. At this point, $\mathrm{CaCO}_{3}$ can precipitate from the water. More than half of the IAPs of $\mathrm{CaCO}_{3}$ for Grande Ronde unit waters and Wanapum unit waters from the Horse Heaven Hills are undersaturated (fig. 27). Comparison of the SI data with $\mathrm{Na}$ concentrations (fig. 28) shows a relation similar to that on figure 25 , one of increasing $\mathrm{CaCO}_{3}$ saturation with evolution.

The change from strongly undersaturated to calcite equilibrium between sites 2 and 5 (SI changes from - 0.284 to -0.029 , fig. 28 ) in the Horse Heaven Hills demonstrates an interesting aspect of hydrochemical evolution of the ground waters in the basalt-intermediate freshening of the ground water. Although figure 10 shows a roughly linear increase of $\mathrm{Na}$ with dissolved solids, the figure does not show the sequential evolution of basalt-water reaction. The relation between residual dissolved-solids (residue remaining after evaporation at $180^{\circ} \mathrm{C}$ ) and dissolved $\mathrm{Na}$ concentrations (fig. 29) for samples from the Horse Heaven Hills (table 4) shows an inflection in the data for site 5 . Sites 2 and 5 approximately lie on a flow line (see fig. 15), and the residual dissolved-solids change between the two is about $0.25 \mathrm{mg} / \mathrm{L}$. Although the $\mathrm{CaCO}_{3}$ saturation and the $\mathrm{Na}$ concentration increased at sites, the residual dissolved solids decreased. Together, this suggests that glass dissolution at that stage of evolution results in a net decrease of dissolved constituents. This is interesting in that the water at site 5 represents a mixing of Wanapum unit water with water from deeper within the system. Steinkampf and others (1985) suggested that part of the dissolved suite at site 5 is derived from an upward flux from the underlying Grande Ronde unit because of the presence of a local hydrogeologic flow impediment immediately downgradient from the well (Packard and others, U.S. Geological Survey, written commun., 1984).

Although the contribution of more evolved water should increase the solute load (particularly because the dominant cation in such a water is $\mathrm{Na}$ ), this mixed water at site 5 is less saline than the water that is upgradient.

The decrease in solute load probably is caused by the precipitation of calcite, driven both by the increase in $\mathrm{Ca}$ and $\mathrm{CO}_{3}$ concentrations due to the hydrolysis of basaltic glass and by the addition of Grande Ronde unit water. The $\mathrm{CaCO}_{3}$ equilibrium line (fig. 27) is a non-linear relation, and the addition of warmer Grande Ronde unit water to the Wanapum unit water will yield a water of intermediate temperature that is more saturated with respect to $\mathrm{CaCO}_{3}$ than the end-member waters. This condition, combined with the much larger $\mathrm{Ca}$ concentration in upgradient water, the accumulation of $\mathrm{HCO}_{3}$ and $\mathrm{CO}_{3}$ as the hydrolysis reaction proceeds, and the attendant $\mathrm{pH}$ increase, leads to a greater probability of $\mathrm{CaCO}_{3}$ precipitation. 


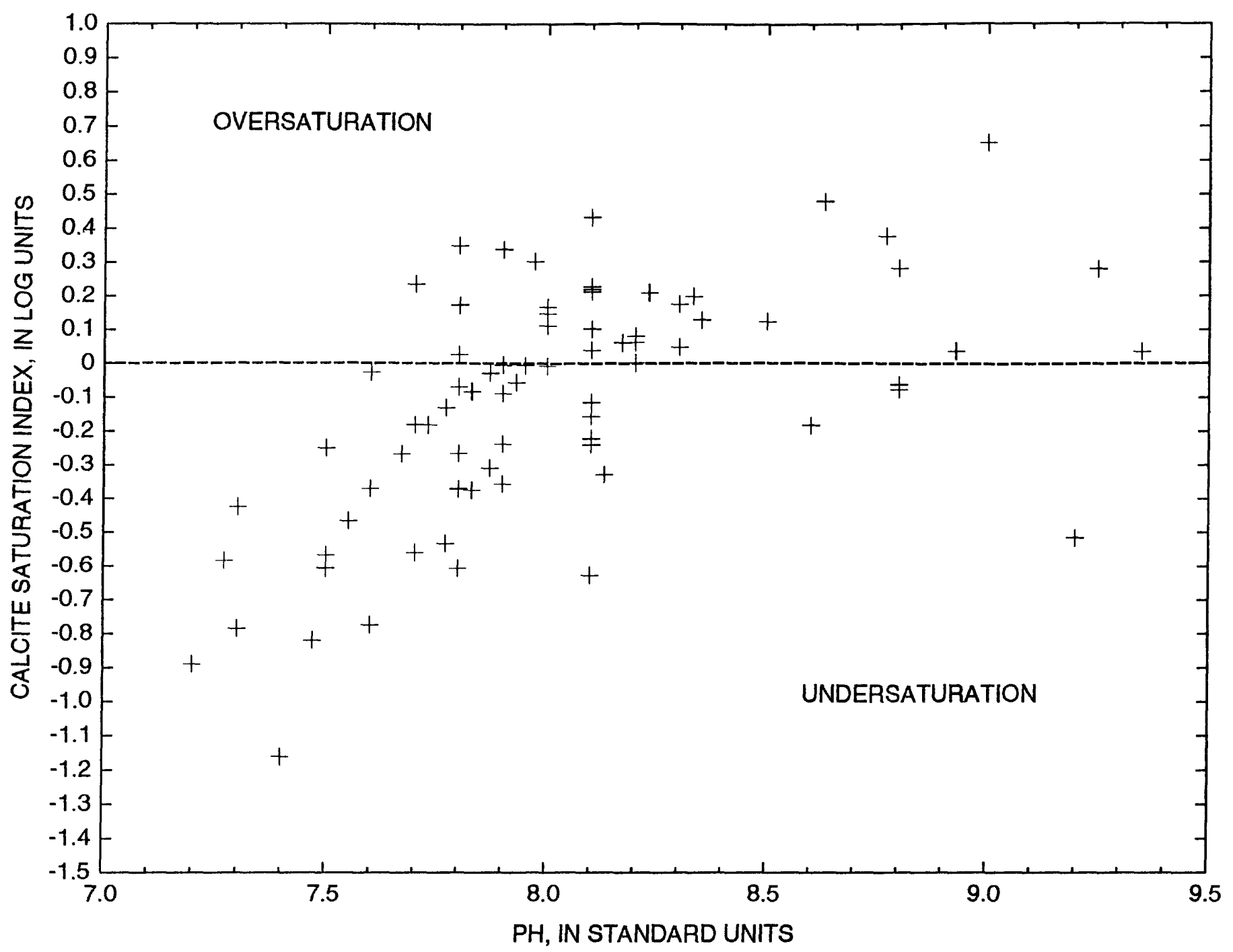

Figure 25.--Relation between calcite saturation index (calculated using data in table 6) and $\mathrm{pH}$ for the Grande Ronde unit. 


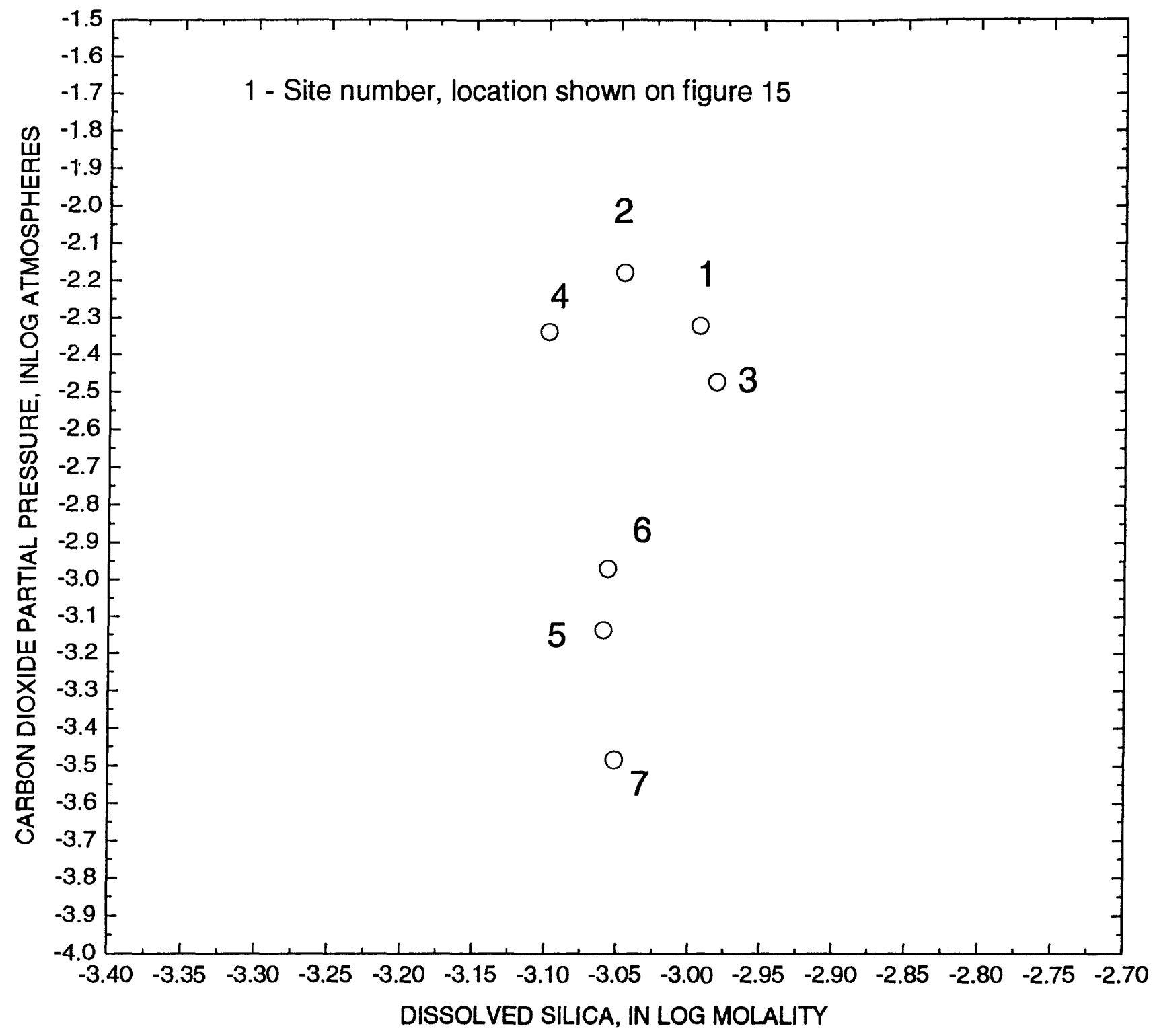

Figure 26.--Relation between carbon dioxide partial pressure and silica activity (both calculated using data in table 6) for selected sites in the Horse Heaven Hills. 


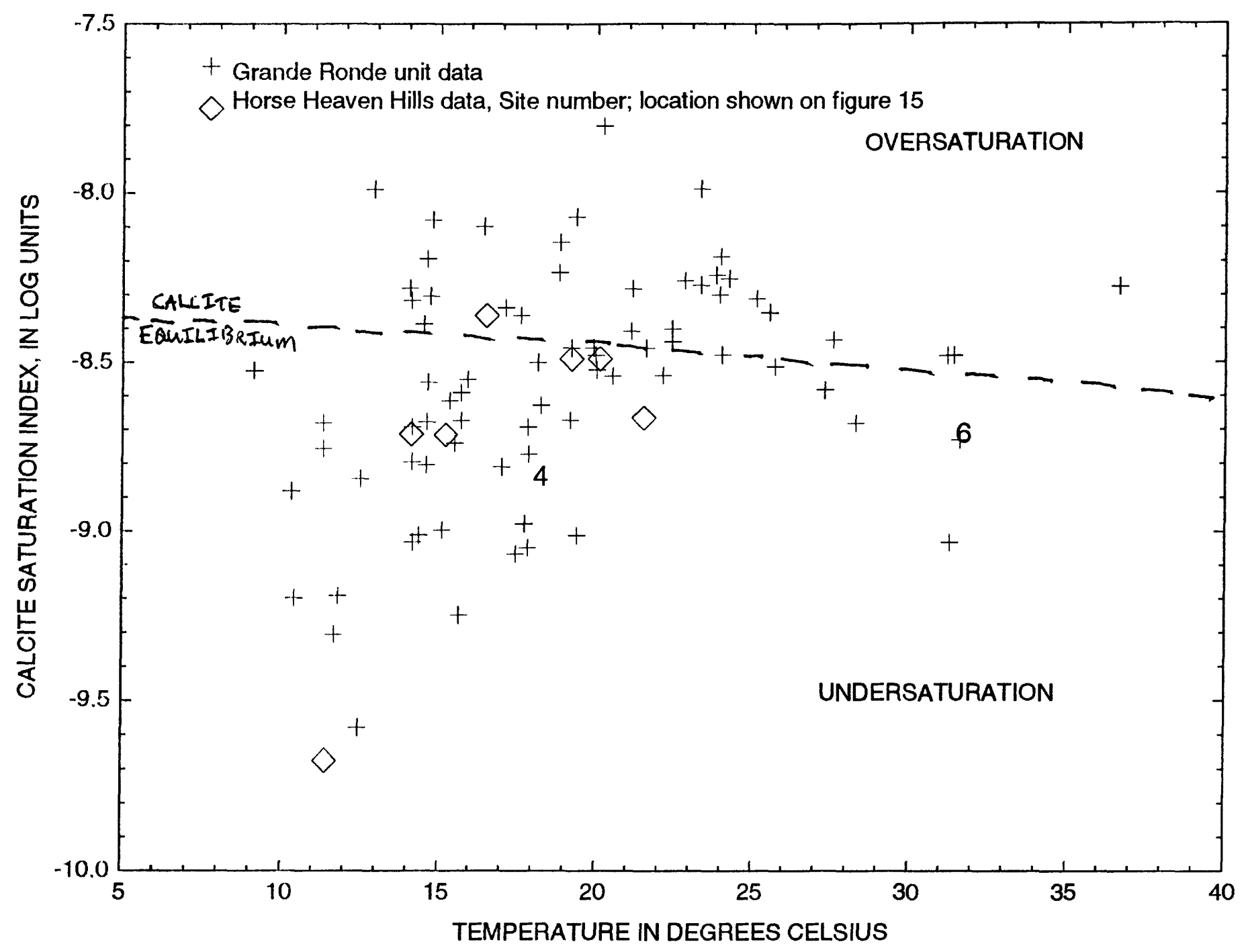

Figure 27.--Relation between calcite ion activity product (A) and ground-water temperature for the Grande Ronde unit and selected sites in the Horse Heaven Hills. IAP was calculated using data from table 6 for the Grande Ronde unit and data from table 4 for the Horse Heaven Hills. The calcite equilibrium curve was constructed using equation 57 from Plummer and Busenberg (1982). 


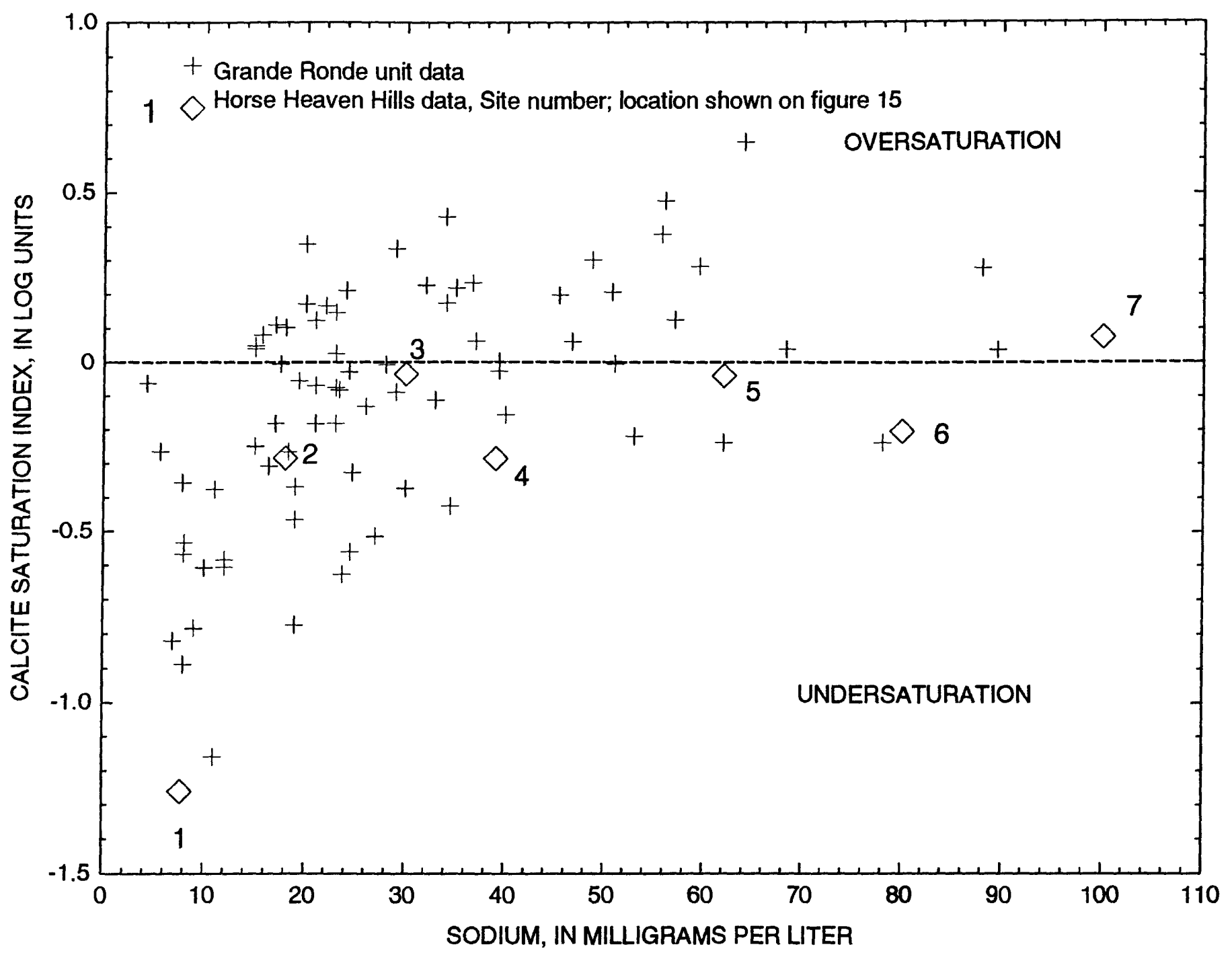

Figure 28.--Relation between calcite saturation index (SI) and dissolved sodium concentrations for the Grande Ronde unit and selected sites in the Horse Heaven Hills. SI was calculated using data from table 6 for the Grande Ronde unit and data from table 4 for the Horse Heaven Hills. 


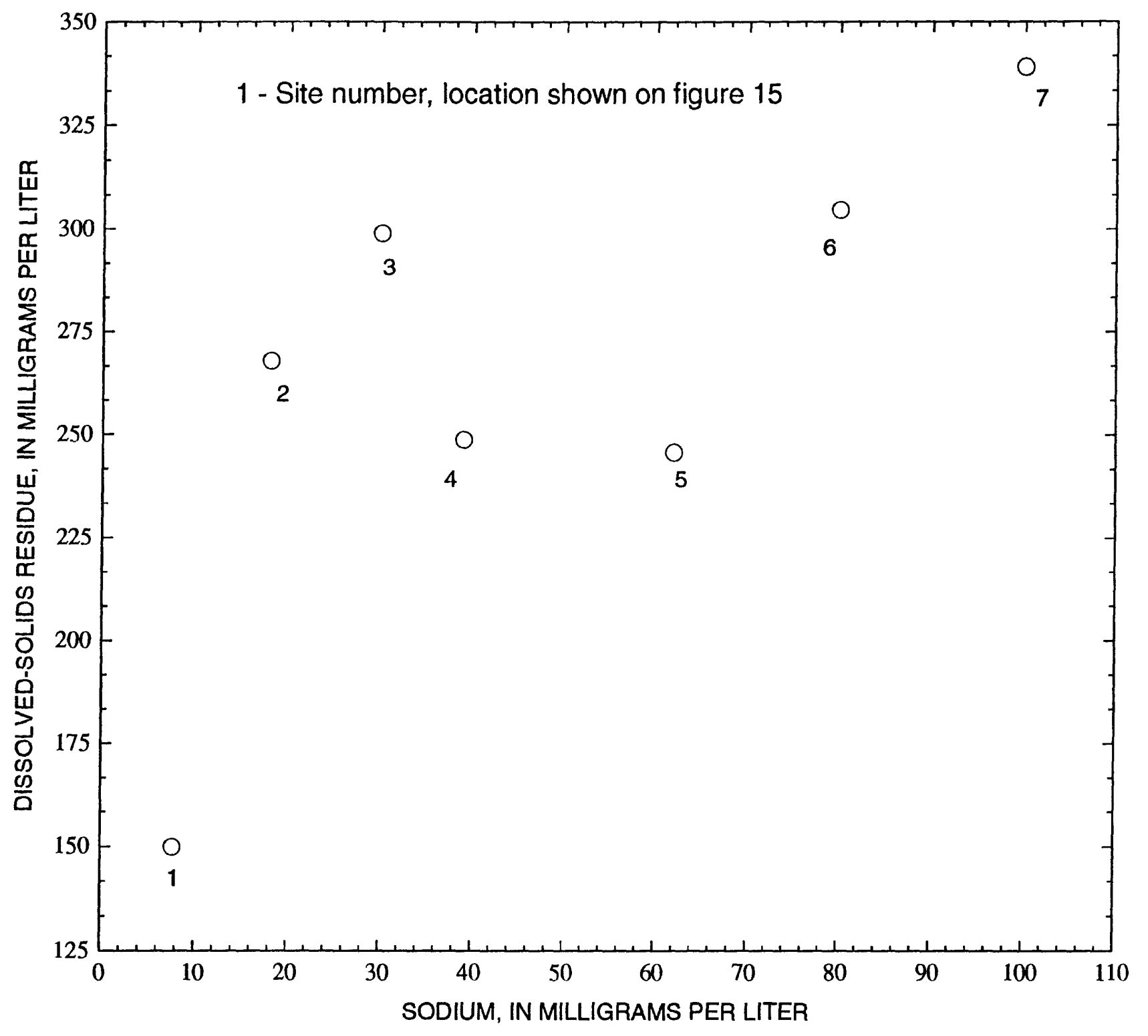

Figure 29.--Relation between dissolved-solids residue and dissolved sodium concentrations for selected wells in the Horse Heaven Hills. Data from table 4. 
With the exception of calcite, the secondary minerals or phase described in this section have been found in fairly distinct and regular sequences in vesicles and fractures in the Columbia River Basalt Group. Benson and Teague (1982) proposed a formation sequence as follows: primarily nontronitic clay $\rightarrow>$ clinoptilolite $->$ silica and clay. Hearn and others $(1984,1985)$ suggested, based on their observations of admixtures of smectite and iron oxides, that these phases tend to co-precipitate. Multiple generations of one or more phases, generally smectites and (or) clinoptilolite, commonly compose compositionally distinct layers that are in close proximity (indicating co-precipitation). Hearn and others $(1984,1985)$ noted this in numerous vesicles.

\section{Basalt-Water Mass Balance}

A general reaction can be written for the dissolution of basaltic glass using information describing water, glass, and secondary mineral chemistries. One of the simplest means of establishing stoichiometric coefficients for the reactants and products is a mass balance calculation. The calculation incorporates plausible reacting phases with known end-member water chemistries, quantifies both inputs to and losses from solution, and identifies the contributing or gaining phases. Although calculations of this nature almost always yield non-unique solutions that are not thermodynamically constrained, they provide a means to examine the feasibility of proposed reactions.
Hypothetical reactions along two flow paths were examined to gain insight to the possible relevance of the calculated mass balances and to obtain best estimates of an equilibrium reaction equation. The calculation scheme used is BALANCE (Parkhurst and others, 1982). Glass, smectite, and zeolite compositions used are those in table 1. Water chemistries for one flow path are from the August 1983 samples from Grande Ronde unit sites 1, 2, and 3 (table 5; sites 45,55 , and 59 in table 6). Water chemistries for the second flow path are from Wanapum unit sites 2 and 5 from the Horse Heaven Hills (table 4, fig. 15). The Grande Ronde unit sites are on a groundwater flow line, based on the spring 1983 potentiometric map of the Grande Ronde unit (Bauer and others, 1985).

It should be noted that the reason that all of the "requisite" phases are not present in reactions 8 and 9 given below is that BALANCE solves a set of linearly independent equations for which the number of possible phases in each solution is equal to the number of elements in the input set. Although it is possible that every phase should appear in reactions 8 and 9, BALANCE cannot account for all phases. Additionally, small changes in the solidphase concentrations of common species such as $\mathrm{Ca}$ and $\mathrm{Na}$ could result in large changes in the results of the calculations.

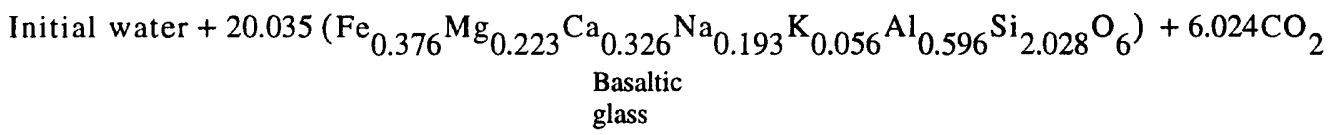

$$
\begin{aligned}
& +0.021 \mathrm{FeS}_{2}+9.645 \mathrm{CHOH} \leftrightarrow 5.881 \mathrm{CaCO}_{3}+8.928 \mathrm{SiO}_{2}+4.347 \mathrm{Fe}(\mathrm{OH})_{3} \\
& \text { Pyrite Calcite Silica } \quad \text { Ferric } \\
& \text { oxyhydroxide }
\end{aligned}
$$

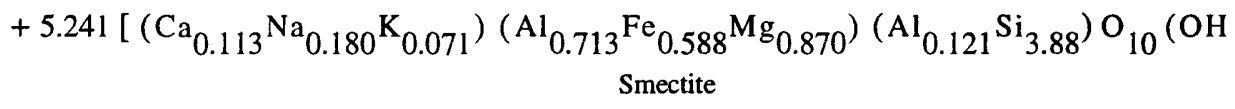

$$
\begin{aligned}
& +\underset{0.48}{+0.788\left[\mathrm{Ca}_{0.88} \mathrm{~K}_{0.98} \mathrm{Al}_{3.0} \mathrm{Fe}_{0.20} \mathrm{Mg}_{0.10}\left(\mathrm{Al}_{0.66} \mathrm{Si}_{1.34}\right) \mathrm{Si}_{13} \mathrm{O}_{36}\right]+\text { Final water. }}
\end{aligned}
$$


Reaction 8 is based on the Grande Ronde unit flow path and includes basaltic glass, $\mathrm{CO}_{2}$, and pyrite $\left(\mathrm{FeS}_{2}\right)$ as reacting phases and $\mathrm{CaCO}_{3}, \mathrm{SiO}_{2}$, ferric oxyhydroxide $\left(\mathrm{Fe}(\mathrm{OH})_{3}\right)$, and average smectite and clinoptilolite as products. Pyrite was included to account for a downgradient $\mathrm{SO}_{4}$ concentration increase and because Ames (1980) reported minor occurrences of metallic sulfide phases. The analytical data for the upgradient and downgradient sites ( 3 and 1, table 5), together with the reactant and product phase compositions, are the data input to BALANCE. The results were constrained by specifying that BALANCE account for changes in the concentrations of $\mathrm{Ca}$, $\mathrm{Mg}, \mathrm{Fe}, \mathrm{Na}, \mathrm{K}, \mathrm{S}, \mathrm{Si}$, and $\mathrm{C}$, and for electron transfer necessitated by changes in elemental oxidation state:

Reaction 8 is only one of many that satisfy the mass balance constraints between the two Grande Ronde unit sites. It was, however, the only solution that included all of the phases estimated to be involved on the basis of mineralogic evidence, speciation/equilibrium calculations, and previous studies. Other mass-balance calculations that were completed included solute sources such as augite and labradorite. Although these minerals are abundant in the basalts, their inclusion in plausible reactions was discarded primarily because basaltic glass is more soluble than crystalline basalt, and because of the glassy nature of the basalt flow tops and bases, both of which compose the most permeable part of the basalt flow sequence. Other solutions obtained using the addition of an exchange reaction ( $2 \mathrm{Na}$ for $\mathrm{Ca}$ ) were not satisfactory because $\mathrm{CaCO}_{3}$ did not precipitate and the sign of the exchange reaction was incorrect. Although exchange is likely a mechanism inherent in hydrochemical evolution, its effect was not detected in the examination of the data sets and it could not be satisfactorily addressed in the mass-balance calculations.

Another possible source of dissolved materials in the downgradient water on the flow path for the Grande Ronde unit is water from deeper in the Grande Ronde unit. Site 1 (table 5) is a large-capacity irrigation well located just east of the CBIP, at the downgradient end of the flow path and in the general area where extensive ground-water withdrawals have altered, and in some cases reversed, gradients between the Grande Ronde and Wanapum units. It is possible that upward flow from lower parts of the Grande Ronde unit contributes to the pumped discharge at this site. On the basis of this hypothesis, the composition of water from site 2, which is completed deeper in the Grande Ronde unit and is between sites 1 and 3, was included as an additional possible "phase" in the mass balance calculation. This addition resulted in solutions in which $\mathrm{CaCO}_{3}$ or $\mathrm{Fe}(\mathrm{OH})_{3}$ did not precipitate, or in which unrealistically large mass transfers were indicated. These results are not in accord with the conceptual model suggested by Hearn and others (1985), but agree with some secondary mineral data. Benson and Teague (1982), as noted earlier, reported the absence of $\mathrm{CaCO}_{3}$ between depths of about 1,100 and 3,100 ft, and Hearn and others (1984) found Fe oxides to be present only above depths of about $1,000 \mathrm{ft}$. This suggests that the conceptual model also may need to include dissolution of secondary phases in the later stages of the evolutionary process.

Reaction 9 is a hypothetical reaction for the Horse Heaven Hills flow path:

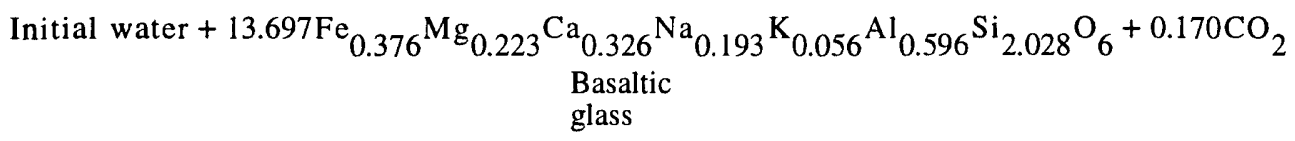

$$
\begin{aligned}
& +4.507 \mathrm{CHOH} \leftrightarrow 4.953 \mathrm{Mg}_{0.2} \mathrm{Ca}_{0.8} \mathrm{CO}_{3}+11.462 \mathrm{SiO}_{2} \\
& \text { Organic Calcite Silica } \\
& \text { carbon } \\
& +0.135 \mathrm{H}_{2} \mathrm{~S}+2.781 \mathrm{Fe}(\mathrm{OH})_{3}+0.201 \mathrm{KAlSi}_{3} \mathrm{O}_{8} \\
& \begin{array}{lll}
\begin{array}{l}
\text { Hydrogen } \\
\text { sulfide }
\end{array} & \begin{array}{l}
\text { Ferric } \\
\text { oxyhydroxide }
\end{array} & \text { Adularia }
\end{array}
\end{aligned}
$$

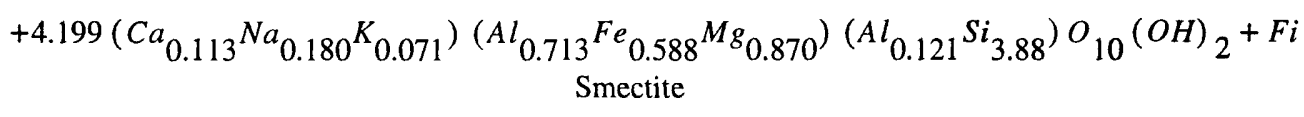


Reaction 9 was obtained using the same mass-balance constraints used to obtain reaction 8 for the flow path of the Grande Ronde unit. It differs from reaction 8 in three ways. The first difference is that adularia replaces clinoptilolite as a precipitating phase. These waters are much less evolved than the downgradient water in the Grande Ronde unit flow path, and clinoptilolite has not been observed in rocks from depths above $1,180 \mathrm{ft}$. Additionally, the Horse Heaven waters evolve from undersaturated (site 2) to oversaturated (site 5) with respect to adularia (SI, changes from -0.61 to 1.57 ).

The second difference is the degassing of hydrogen sulfide $\left(\mathrm{H}_{2} \mathrm{~S}\right)$ needed in order to satisfy a decrease in $\mathrm{SO}_{4}$ concentration. It is possible that this decrease is due, in part, to a larger-than-natural $\mathrm{SO}_{4}$ concentration at site 2 , possibly derived from the previously discussed anthropogenic input. Although sulfide $\left(\mathrm{S}^{2-}\right)$ analyses were not performed, the odor of $\mathrm{H}_{2} \mathrm{~S}$ was noted during sample collection at site 5 , suggesting that bacterial reduction of $\mathrm{SO}_{4}$ is a process that needs to be accounted for. Although the decrease in $S$ concentration may be due to precipitation of a $S^{2-}$ mineral, this cannot be quantified without more detailed sampling.

The third difference is the inclusion of organic carbon $(\mathrm{CHOH})$ as a plausible reacting phase. The organic carbon provides an energy source for the assumed reduction of $\mathrm{SO}_{4}$ to $\mathrm{S}^{2-}$. This difference included the omission of DO from the calculations; a solution could not be obtained that included $\mathrm{CO}_{2}, \mathrm{DO}, \mathrm{CHOH}$, and $\mathrm{H}_{2} \mathrm{~S}$.

Last, satisfactory solutions did not result until 2-mole-percent $\mathrm{MgCaCO}_{3}$ (in contrast to $\mathrm{CaCO}_{3}$ in eq. 8) was input as a possible phase. This is not unreasonable, as all natural calcites are stoichiometrically diverse, constraining variable amounts of divalent metals, such as barium, cadmium, magnesium, strontium, and others in the crystal lattice.

Reactions 8 and 9 include known basalt mineralogy, end-member water chemistry, and observed secondary phases. Mass-balance calculations indicate that these reactions account for the spatial variations of chemistry along two flow paths and thus support the conceptual model of chemical evolution proposed by Hearn and others (1985). Important components for the conceptual model are the identification of the major hydrochemical processes, and the control of secondary phases or minerals and how this control varies with the evolutionary stage. The latter was demonstrated for the Horse Heaven Hills flow path in the Wanapum unit by the substitution of adularia in reaction 9 in place of clinoptilolite in reaction 8. Reaction 9 represents less evolved waters than those for reaction 8 , and thus the control of secondary minerals is different.

\section{SUMMARY AND CONCLUSIONS}

The Columbia Plateau aquifer system comprises Miocene basalts of the Columbia River Basalt Group and is the primary ground-water source in eastern Washington, north-central and northeastern Oregon, and parts of west-central Idaho. The basalts are recharged in roughly those areas where precipitation is greater than about $8 \mathrm{in} / \mathrm{yr}$. The principal directions of ground-water flow throughout the plateau are downward to the Grande Ronde unit and laterally toward major streams. Agriculture is the largest ground-water user, and withdrawals have resulted in large water-level declines and changes in hydraulic gradients. These effects, together with extensive use of surface water for irrigation in the Columbia Basin Irrigation Project, have affected ground-water chemistry in some areas.

Plateau ground waters are primarily fresh calcium-magnesium-bicarbonate or sodium-bicarbonate waters that are suitable for most uses. The general distribution of these water types is from upgradient to downgradient areas, respectively. Although divalent cation concentrations decrease, dissolved elemental concentrations generally increase both downgradient and with depth in the aquifer system.

Spatial hydrochemical variations derive from chemical reactions between the ground waters and the basalts and are influenced to some degree by the extent to which the hydrogeologic system is isolated from the atmosphere. Basaltic glass is the most soluble phase in the hydrogeologic units and is the most important source of solutes in the system. Dissolved inorganic carbon derives from both atmospheric and soil-zone carbon dioxide, and possibly from organic material intercalated with the basalts. Dissolution of basaltic glass by hydrolysis and dilute carbonic acid attack rapidly adds solutes to the ground water at an estimated rate of about 2 grams of glass per liter of water per thousand years. 
Dissolution of basaltic glass appears to be stoichiometric, but localized ground-water mixing, secondary mineralization, and perhaps exchange reactions subsequently alter ground-water concentrations. A simplistic reaction scheme based on examinations of the hydrochemical data and reported distributions of secondary minerals is as follows. Glass dissolution results initially in concentrations of most major glass components that are relatively stoichiometric. Dissolved oxygen, if present, rapidly oxidizes dissolved ferrous iron, and aluminum and iron rapidly precipitate as amorphous aluminosilicates and ferric oxyhydroxides. The aluminosilicates also constrain silicon concentrations. These phases become more crystalline over time, and the aluminosilicates, because of structural substitutions, also contain other cations, including calcium, magnesium, sodium, and iron. Ground-water $\mathrm{pH}$ increases as dissolution progresses, and the hydroxyl ion buffering capacity of dissolved silicon may become significant in the more evolved waters. Waters become oversaturated with respect to calcite and several silica phases. Calcite precipitation may be the most important control of calcium concentrations. A poorly crystalline phase, such as $\alpha$-cristobalite, appears to be the most likely silicon phase affecting dissolved silicon concentrations. It is possible that, particularly in the warmest and most evolved waters, secondary adularia and clinoptilolite also restrict dissolved silicon levels. Clinoptilolite also is a probable control of dissolved sodium and potassium concentrations once they, together with silicon, reach sufficiently large concentrations.

Data along a flow path in the Horse Heaven Hills in south-central Washington suggest that basaltic ground waters locally evolve through a phase in which the dissolved load decreases with progressive glass dissolution and mixing of more evolved waters. This is probably because of calcite precipitation, as indicated by a large decrease in calcium and magnesium concentrations. The mixing of warmer Grande Ronde unit waters with less evolved Wanapum unit waters results in a water that is more saturated with respect to calcite and adularia than either end member.

General reactions derived from mass-balance calculations for the Horse Heaven Hills flow path and a flow path in the Grande Ronde unit in the central part of the plateau suggest that the conceptual model of hydrochemical evolution described by Hearn and others (1985) satisfactorily supports most of the observed spatial variations. The reactions also suggest that the relative importance of controlling solid phases varies with evolutionary progress and position within the flow system.

\section{SELECTED REFERENCES}

Ames, L.L., 1980, Hanford basalt flow mineralogy: Richland, Washington, Pacific Northwest, Laboratory Report no. PNL-2847, 447 p.

Arnason, B., 1977, Hydrothermal systems in Iceland traced by deuterium: Geothermics, v. 5, p. 125-151.

Armannsson, H., Gislason, G., and Hauksson, T., 1982, Magmatic gases in well fluids aid the mapping of the flow pattern in a geothermal system: Geochimica et Cosmochimica Acta, v. 46, p. 167-177.

Arnorsson, S., Gunnlaugsson, E., and Svarsson, H., 1983a, The chemistry of geothermal waters in Iceland II: Mineral equilibria and independent variables controlling water compositions: Geochimica et Cosmochimica Acta, v. 47, p. 547-566.

$1983 \mathrm{~b}$, The chemistry of geothermal waters in Iceland, III: Chemical geothermometry in geothermal investigations: Geochimica et Cosmochimica Acta, v. 47 , p. $567-577$.

Ball, J.W., Jenne, E.A., and Nordstrom, D.K., 1979, WATEQ2-a computerized chemical model for trace and major element speciation and mineral equilibria of natural waters: U.S. Geological Survey Water-Resources Investigations Report 78-116, 109 p.

Ball, J.W., Nordstrom, D.K., and Jenne, E.A., 1980, Additional and revised thermochemical data and computer code for WATEQ2-a computerized chemical model for trace and major element speciation and mineral equilibria of natural waters: U.S. Geological Survey Water-Resources Investigations Report 78-116, 109 p.

Bauer, H.H., and Vaccaro, J.J., 1990, Estimates of ground-water recharge to the Columbia Plateau regional aquifer system, Washington, Oregon, and Idaho, for predevelopment and current land-use conditions: U.S. Geological Survey Water-Resources Investigations Report 88-4108, 2 plates, $37 \mathrm{p}$.

Bauer, H.H., and Hansen, A.J., in press, Hydrology of the Columbia Plateau regional aquifer system, Washington, Oregon, and Idaho: U.S. Geological Survey Water-Resources Investigations Report 96-4106. 
Bauer, H.H., Vaccaro, J.J., and Lane, R.C., 1985, Maps showing ground-water levels in the Columbia River Basalt Group and overlying materials, spring 1983, southeastern Washington: U.S. Geological Survey Water-Resources Investigations Report 84-4360, scale $1: 500,000,4$ sheets.

Benson, L.V., and Teague, L.S., 1982, Diagenesis of basalts from the Pasco Basin, Washington, I: Distribution and composition of secondary mineral phases: Journal of Sedimentary Petrology, v. 52, no. 2, p. 595-613.

Bortleson, G.C., and Cox, S.E., 1985, Occurrence of dissolved sodium in ground waters of basalts underlying the Columbia Plateau, Washington: U.S. Geological Survey Water-Resources Investigations Report 85-4005, scale 1:500,000, 6 sheets.

Chesworth, W., Dejou, J., and Larroque, P., 1981, The weathering of basalt and relative mobilities of the major elements at Belbex, France: Geochimica et Cosmochimica Acta, v. 45, p. 1,235-1,243.

Cline, D.R., 1984, Ground-water levels and pumpage in east-central Washington, including the Odessa-Lind area, 1967 to 1981: Washington State Department of Ecology Water-Supply Bulletin No. 55, 34 p.

Cline, D.R., and Knadle, M.E., 1990, Ground-water pumpage from the Columbia Plateau regional aquifer system, Washington, 1984: U.S. Geological Survey Water-Resources Investigations Report 87-4135, 1 plate, $32 \mathrm{p}$.

Collins, C.A., 1987, Ground-water pumpage from the Columbia Plateau regional aquifer system, Oregon, 1984: U.S. Geological Survey Water-Resources Investigations Report 86-4211, 1 plate, $21 \mathrm{p}$.

Davies-Smith, A., Bolke, E.L., and Collins, C.A., 1988, Geohydrology and digital simulation of the groundwater flow system in the Umatilla Plateau and Horse Heaven Hills area, Oregon and Washington: U.S. Geological Survey Water-Resources Investigations Report 87-4260, 70 p.

Deutsch, W.J., Jenne, E.A., and Krupka, K.M., 1982, Solubility equilibria in basalt aquifers: The Columbia Plateau, eastern Washington, U.S.A.: Chemical Geology, v. 36, p. 15-34.
Drost, B.W., and Whiteman, K.J., 1986, Surficial geology, structure and thickness of selected geohydrologic units in the Columbia Plateau, Washington: U.S. Geological Survey Water-Resources Investigations Report 84-4326, scale 1:500,000, 10 sheets.

Drost, B.W., Whiteman, K.J., and Gonthier, J.B., 1990, The geologic framework of the Columbia Plateau aquifer system, Washington, Oregon, and Idaho: U.S. Geological Survey Water-Resources Investigations Report 87-4238, scale 1:500,000, 10 sheets, 10 p.

Ebbert, J.C., 1984, The quality of ground water in the principal aquifers of northeastern-north-central Washington: U.S. Geological Survey Water-Resources Investigations Report 83-4102, $112 \mathrm{p}$.

Ellis, A.J., and Mahon, W.A.J., 1964, Natural hydrothermal systems and experimental hot water-rock interactions I: Ceochimica et Cosmochimica Acta, v. 28, p. 1,323-1,357.

1967, Natural hydrothermal systems and experimental hot water-rock interactions II: Geochimica et Cosmochimica Acta, v. 31, p. 519-531.

Farooqui, S.M., Clayton, D.C., Bunker, R.C., Bela, J.L., and Thoms, R.E., 1981, Post Columbia River Basalt Group stratigraphy and map compilation of the Columbia Plateau, Oregon: Oregon Department of Geology and Mineral Industries Open-File Report 0-81-10, 79 p., scale 1:250,000.

Fournier, R.O., 1985, Reviews in Economic Geology, v. 2: in Geology and Geochemistry of Epithermal Systems, Berger, B.R., and Bethke, P.M., eds.: Society of Economic Geologists, p. 45-61.

Friedman, I., and O'Neil, J.R., 1977, Compilation of stable isotope fractionation factors of geochemical interest: M. Fleischer, ed.: U.S. Geological Survey Professional Paper 440-KK, 108 p.

Furnes, H., 1975, Experimental palagonitization of basaltic glass of varied composition: Contribution to Mineralogy and Petrology, v. 50, p. 105-113. 
Gat, J.R., 1980, The isotopes of hydrogen and oxygen in precipitation: in Ftitz and Ch. Fontes, eds.: Handbook of Environmental Isotope Geochemistry, v. 1--The Terrestial Environment, Amsterdam, Elsevier, p. 21-47.

Gislason, S.R., and Eugster, H.P., 1987a, Meteoric water-basalt interactions I: A laboratory study: Geochimica et Cosmochimica Acta, v. 51, p. $2,827-2,840$.

1987b, Meteoric water-basalt interaction I: A field study in N.E. Iceland: Geochimica et Cosmochimica Acta, v. 51, p. 2,841-2,855.

Gonthier, J.B., 1989, Geology, structure, and thickness of selected geohydrologic units in part of the Columbia Plateau, Oregon: U.S. Geological Survey Water-Resources Investigations Report 86-4001, scale $1: 500,000,6$ sheets.

Hansen, A.J., Jr., Vaccaro, J.J., and Bauer, H.H., 1994, Ground-water flow simulation of the Columbia Plateau regional aquifer system, Washington, Oregon and Idaho: U.S. Geological Survey Water-Resources Investigations Report 91-4187, 15 plates, $101 \mathrm{p}$.

Hawkins, D.B., and Roy, R., 1963, Experimental hydrothermal studies on rock alteration and lay mineral formation: Geochimica et Cosmochimica Acta, v. 27, p. 1,047-1,054.

Hay, R.L., and Jones, B.F., 1972, Weathering of basaltic tephra on the island of Hawaii: Geological Society of America Bulletin, v. 83, p. 317-332.

Hay, R.L., Pexton, R.E., Teague, T.T., and Kyser, T.K., 1986, Spring-related carbonate rocks, magnesium clays, and associated minerals in Pliocene deposits of the Amargos Desert, Nevada and California: Geological Society of America Bulletin, v. 97, p. $1,488-1,503$.

Hearn, P.P., Jr., Steinkampf, W.C., and Brown, Z.A., 1984, Characterization of secondary alteration in the Columbia River basalt by backscattered electron imaging and energy-dispersive X-ray spectroscopy, in Romig, A.D., and Goldstein, J.I., eds., Proceedings of the 19th Annual Conference of the Microbeam Analysis Society: Berkeley, California, San Francisco Press, p. 145-148.
Hearn, P.P., Jr., Steinkampf, W.C., Bortleson, G.C., and Drost, B.W., 1985, Geochemical controls on dissolved sodium in basalt aquifers of the Columbia Plateau, Washington: U.S. Geological Survey Water-Resources Investigations Report 85-4304, 38 p.

Hooper, P.R., 1982, The Columbia River Basalts: Science, v. 215 , no. 4,539 , p. $1,463-1,468$.

Hoover, J.D., and Murphy, W.M., 1989, Quench fractionation in Columbia River basalt and implications for basalt-ground water interaction, in Reidel, S.P., and Hooper, P.R., eds., Volcanism and tectonism in the Columbia River flood-basalt province: Boulder, Colorado, Geological Society of America, Special Paper 239, p. 307-320.

Ingerson, E., and Pearson, F.J., Jr., 1964, Estimating of age and rate of motion of ground water by the $\mathrm{C}^{14}$ method, in Recent Researches in the Fields of Hydrosphere, Atmosphere, and Nuclear Geochemistry: Maruzen, Tokyo, p. 263-283.

Jakobsson, S., 1978, Environmental factors controlling the palagonitization of the Surtsey tephra, Iceland: Bulletin of the Geological Society of Denmark, v. 27, p. 91-105.

Jenkins, D., Holloway, J., and Kacoyannalis, J., 1984, Temporal variations of aqueous constituents in a water-basalt-supercalcine system: Implications for the experimental assessment of nuclear waste forms: Geochimica et Cosmochimica Acta, v. 48, p. $1,443-1,454$.

Jones, B.F., 1966, Geochemical evolution of closed basin water in the western Great Basin, in Rau, J.S., ed.: Second Symposium on Salt, Northern Ohio Geological Society, v. 1, p. 181-200.

Laird, L.B., Taylor, H.E., and Lombard, R.E., 1986, Data on snow chemistry of the Cascade-Sierra Nevada Mountains: U.S. Geological Survey Open-File Report 86-61, 25 p. 
Lambert, R. St. J., Marsh, I.K., and Chamberlain, V.E. 1989, The occurrence of interstitial granite glass in all formations of the Columbia River Basalt Group and its petrogenetic implications, in Reidel, S.P., and Hooper, P.R., eds.: Volcanism and tectonism in the Columbia River flood-basalt province: Boulder, Colorado, Geological Society of America, Special Paper 239, p. 321-334.

Lane, R.C., 1988a, Selected ground-water information for the Columbia Plateau regional aquifer system, Washington, and Oregon, 1982-1985: Volume I. Geohydrology: U.S. Geological Survey Open-File Report 88-182, 236 p.

1988b, Selected ground-water information for the Columbia Plateau regional aquifer system, Washington and Oregon, 1982-1985: Volume II. Water Levels: U.S. Geological Survey Open-File Report 88-183, 136 p.

Lane, R.C., and Whiteman, K.J., 1989, Ground-water levels, spring 1985, and ground-water level changes, spring 1983 to spring 1985, in three basalt units underlying the Columbia Plateau, Washington and Oregon: U.S. Geological Survey Water-Resources Investigations Report 88-4018, scale 1:500,000, 4 sheets.

Langmuir, Donald, 1969, Geochemistry of iron in a coastal plain ground water of the Camden, New Jersey, area: U.S. Geological Survey Professional Paper 650-C, p. C224-C235.

Langmuir, Donald, and Whittemore, D.O., 1971, Variations in the stability of precipitated ferric oxyhydroxides, in Nonequilibrium systems in natural-water chemistry: Advances in Chemistry Series, no. 106, Washington D.C., American Chemical Society, p. 209-234.

LaSala, A.M., Jr., and Doty, G.C., 1971, Preliminary evaluation of hydrologic factors related to radioactive waste storage in basaltic rocks at the Hanford Reservation: U.S. Geological Survey Open-File Report, 77-180, 68 p.
Lindholm, G.F., and Vaccaro, J.J., 1988, Region 2, Columbia Lava Plateau, in Back, William, Rosenshein, J.S., and Seaber, P.R., eds.: Hydrogeology, Geology of North America, v. O-1, Boulder, Colorado: Geological Society of America, p. 37-50.

Luzier, J.E., Bingham, J.W., Burt, R.J., and Barker, R.A., 1968, Ground-water survey, Odessa-Lind area, Washington: Washington Department of Water Resources Water-Supply Bulletin No. 36, 31 p.

Luzier, J.E., and Skrivan, J.A., 1975, Digital simulation and projection of water-level declines in basalt aquifers of the Odessa-Lind area, east-central Washington: U.S. Geological Survey Water-Supply Paper 2036, 48 p.

MacNish, R.D., and Barker, R.A., 1976, Digital simulation of a basalt aquifer system, Walla Walla River basin, Washington and Oregon: Washington Department of Ecology Water-Supply Bulletin No. 44, 51 p.

Moore, E., Ulmer, G., and Grandstaff, D., 1983, Hydrothermal interaction of Columbia Plateau basalt from the Umtanum Flow with its coexisting groundwater [abstract]: in Extended abstracts; Fourth international symposium on water-rock interaction, Extended Abstracts: International Symposium on Water-Rock Interaction, Misasa, Japan, p. 356-359.

Mundorff, J.J., MacNish, R.D., and Cline, D.R., 1977, Water resources of the Status Creek Basin, Yakima Indian Reservation, Washington: U.S. Geological Survey Open-File Report 76-685, 102 p.

Myers, C.M., and Price, S.M., 1979, Geologic studies of the Columbia Plateau: a status report: Richland, Washington, Rockwell International, Rockwell Hanford Operations RHO-BWI-ST-4, 520 p.

Nelson, L.M., 1991, Surface-water resources for the Columbia Plateau, Washington, Oregon, and Idaho: U.S. Geological Survey Water-Resources Investigations Report 88-4105, scale 1:500,000, 4 sheets. 
Newcomb, R.C., 1961, Storage of ground water behind subsurface dams in the Columbia River Basalt, Washington and Idaho: U.S. Geological Survey Professional Paper 383-A, $15 \mathrm{p}$.

1965, Geology and ground-water resources of the Walla Walla River basin, Washington-Oregon: Washington Division of Water Resources, Water Supply Bulletin No. 21, 151 p.

1969, Effect of tectonic structure on the occurrence of ground water in the basalt of the Columbia River group of The Dalles area, Oregon and Washington: U.S. Geological Survey Professional Paper 383-C, $33 \mathrm{p}$.

Paces, Tomas, 1973, Steady-state kinetics and equilibrium between ground water and granitic rock: Geochimica et Cosmochimica Acta, v. 37, p. 2,641-2,663.

Parkhurst, D.L., Plummer, L.N., and Thorstenson, D.C., 1982, BALANCE-a computer program for calculating mass transfer for geochemical reactions in ground water: U.S. Geological Survey Water-Resources Investigations Report 82-14, $29 \mathrm{p}$.

Plummer, L.N., and Busenberg, E., 1982, The solubilities of calcite, aragonite and vaterite in $\mathrm{CO}_{2}-\mathrm{H}_{2} \mathrm{O}$ solutions between $0^{\circ}$ and $90^{\circ} \mathrm{C}$ and an evaluation of the aqueous model for the system $\mathrm{CaCO}_{3}-\mathrm{CO}_{2}-\mathrm{H}_{2} \mathrm{O}$ : Geochimica et Cosmochimica Acta, v. 46, p. 1,011-1,040.

Plummer, L.N., Jones, B.R., and Truesdell, A.F., 1976, WATEQF-a Fortran IV version of WATEQ, a computer program for calculating chemical equilibrium of natural waters: U.S. Geological Survey Water-Resources Investigations Report 76-13, revised and reprinted January $1984,70 \mathrm{p}$.

Prych, E.A., 1983, Numerical simulation of ground-water flow in lower Satus Creek basin, Yakima Indian Reservation, Washington: U.S. Geological Survey Water-Resources Investigations Report 82-4065, 78 p.

Raymond, J.R., and Tillson, D.D., 1968, Evaluation of a thick basalt sequence in south-central Washington-geophysical and hydrological exploration of the Rattlesnake Hills deep stratigraphic test well: Atomic Energy Commission Research and Development Report BNWL-776, $126 \mathrm{p}$.
Ross, C.S., and Hendricks, S.B., 1946, Minerals of the montmorillonite group: U.S. Geological Survey Professional Paper, 205-B, 79 p.

Sigvaldason, G.E., and Oskarsson, N., 1976, Chlorine in basalts from Iceland: Geochimica et Cosmochimica Acta, v. 40, p. 777-789.

Smiley, C.J., 1963, The Ellensburg flora of Washington: University of California Publications in Geological Sciences, v. 35-3, p 159-276.

Steinkampf, W.C., 1989, Water-quality characteristics of the Columbia Plateau regional aquifer system in parts of Washington, Oregon, and Idaho: U.S. Geological Survey Water-Resources Investigations Report 87-4242, 37 p.

Steinkampf, W.C., Bortleson, G.C., and Packard, F.A., 1985 , Controls on ground-water chemistry in the Horse Heaven Hills, south-central Washington: U.S. Geological Survey Water-Resources Investigations Report 85-4048, 26 p.

Swanson, D.A., Wright, T.L., Hooper, P.R., and Bentley, R.D., 1979, Revisions in stratigraphic nomenclature of the Columbia River Basalt Group: Contributions to stratigraphy: U.S. Geological Survey Bulletin $1457-\mathrm{G}, 59 \mathrm{p}$.

Tanaka, H.H., Barrett, G.T., and Wildrick, L., 1979, Regional basalt hydrology of the Columbia Plateau in Washington: Richland, Washington, Rockwell Hanford Operations, Report RHO-BWI-C-60, 303 p.

Tanaka, H.H., Hansen, A.J., Jr., and Skrivan, J.A., 1974, Digital-model study of ground-water hydrology, Columbia Basin Irrigation Project area, Washington: Washington Department of Ecology Water-Supply Bulletin No. 40,60 p.

Tolan, T.L., Reidd, S.P., Beeson, M.H., Anderson, J.L., Fecht, K.R., and Swanson, D.A., 1987, Revisions to the areal extent and volume of the Columbia River Basalt Group: Geological Society of America, Abstracts with Programs, v. 19, no. 6, p. 458.

Vaccaro, J.J., 1986, Plan of study for the Regional Aquifer System Analysis, Columbia Plateau, Washington, Northern Oregon, and Northwestern Idaho: U.S. Geological Survey Water-Resources Investigations Report 85-4151, 25 p. 
Vaccaro, J.J., in press, Summary of the Columbia Plateau Regional Aquifer System Analysis, Washington, Oregon, and Idaho: U.S. Geological Survey Professional Paper 1413-A.

Wagner, R.A., and Lane, R.C., 1994, Selected ground-water information for the Columbia Plateau regional aquifer system, Washington and Oregon, 1982-1985: Volume III. Water Quality: U.S. Geological Survey Open-File Report 93-359, 230 p.

White, A.F., 1983, Surface chemistry of dissolution kinetics of glassy rocks at $25^{\circ} \mathrm{C}$.: Geochimica et Cosmochimica Acta, v. 47, p. 805-815.

White, A.F., and Claassen, H.C., 1979, Dissolution kinetics of silicate rocks--Applications to solute modeling: in Jeanne, E.A., ed., Chemical Modelling in Aqueous Systems: American Chemical Society, p. 446-473.

White, A.F., Claassen, H.C., and Benson, L.V., 1980, The effect of dissolution of volcanic glass on the water chemistry in a tuffaceous aquifer, Rainier Mesa, Nevada: U.S. Geological Survey Water-Supply Paper 1535-Q, 34 p.
Whiteman, K.J., 1986, Ground-water levels in three basalt geohydrologic units underlying the Columbia Plateau in Washington and Oregon, spring 1984: U.S. Geological Survey Water-Resources Investigation Report 86-4046, scale 1:500,000, 4 sheets.

Whiteman, K.J., Vaccaro, J.J., Gonthier, J.B., and Bauer, H.H., 1994, Hydrogeologic framework and geochemistry of the Columbia Plateau regional aquifer system, Washington, Oregon, and Idaho: U.S. Geological Survey Professional Paper 1413-B, 73 p.

Wood, W.W., and Low, W.H., 1986, Aqueous geochemistry and diagenesis in the eastern Snake River Plain aquifer system, Idaho: Geological Society of America Bulletin, v. 97, p. 1,456-1,466.

Wood, W.W., and Low, W.H., 1988, Solute geochemistry of the Snake River Plain regional aquifer system, Idaho and eastern Oregon: U.S. Geological Survey Professional Paper 1408-D., 79 p.

Wright, T.L., Swanson, D.A., Helz, R.T., and Byerly, G.R., 1979, Major oxide, trace element, and glass chemistry of Columbia River basalt samples collected between 1971 and 1977: U.S. Geological Survey Open-File Report 79-711, 160 p. 